Portland State University

PDXScholar

Spring 6-12-2018

\title{
"On the Murder of Rickey Johnson": the Portland Police Bureau, Deadly Force, and the Struggle for Civil Rights in Oregon, 1940 - 1975
}

Katherine Elleen Nelson

Portland State University

Follow this and additional works at: https://pdxscholar.library.pdx.edu/open_access_etds

Part of the United States History Commons

Let us know how access to this document benefits you.

\section{Recommended Citation}

Nelson, Katherine Elleen, "''On the Murder of Rickey Johnson": the Portland Police Bureau, Deadly Force, and the Struggle for Civil Rights in Oregon, 1940 - 1975" (2018). Dissertations and Theses. Paper 4434. https://doi.org/10.15760/etd.6318

This Thesis is brought to you for free and open access. It has been accepted for inclusion in Dissertations and Theses by an authorized administrator of PDXScholar. Please contact us if we can make this document more accessible: pdxscholar@pdx.edu. 
"On the Murder of Rickey Johnson": The Portland Police Bureau, Deadly Force, and the Struggle for Civil Rights in Oregon, 1940-1975

by

Katherine Eileen Nelson

A thesis submitted in partial fulfillment of the requirements for the degree of

Master of Arts

in

History

Thesis Committee:

Marc Rodriguez, Chair

Patricia Schechter

David Johnson

Darrell Millner

Portland State University

2018 
(C) 2018 Katherine Eileen Nelson 


\begin{abstract}
On March 14, 1975, twenty-eight year old Portland police officer Kenneth Sanford shot and killed seventeen-year-old Rickie Charles Johnson in the back of the head during a sting operation. Incredulously, Johnson was the fourth person of color to be shot and killed by Portland police within a five-month period. Due to his age and surrounding circumstances, Johnson's death by Sanford elicited extreme reactions from varied communities of Portland. Unlike previous deaths of people of color by the police in Portland, Johnson's death received widespread attention from mainstream media outlets. In response, some white citizens decried Johnson's death as unjustified police brutality. Still, several white citizens defended the Portland Police Bureau and their actions. Members of Portland's African American community, however, firmly believed that Johnson's death was just another instance in the PPB's long history of police brutality within Portland's black neighborhoods.

Johnson's death motivated young black activists in Portland, Oregon to form the advocacy group the Black Justice Committee (BJC). The BJC, along with several preestablished advocacy groups in Portland, demanded that the city host its first public inquest to investigate Johnson's death. A public inquest is a public "trial" that usually occurs after a sudden or unexpected death. Black citizens felt this public inquest would hold the city accountable for repeated mistreatment of the city's communities of color; whereas, the nearly all white city government believed a public inquest would quell racial unrest within Portland. Mayor Neil Goldschmidt and District Attorney Harl Haas agreed to host the inquest, at which assistant District Attorney John Moore questioned Officer Sanford's motivations and actions. Despite the advocacy efforts before the public inquest,
\end{abstract}


the jury voted 4-1 for Sanford's innocence. The only black jury member casted the sole vote against Sanford's innocence.

Heralded for its progressivity, the city of Portland, Oregon is contemporarily viewed as a liberal mecca where all are welcome to speak their truth and "Keep Portland Weird." However, communities of color have experienced widespread repression, oppression and discrimination since the establishment of the city. Whereas some may see Portland as a city that cherishes individuality, Portland's black community has been robbed of autonomy for generations. Police surveillance, harassment and brutality have plagued Portland's black community for years and continues to be a contentious issue within the city.

This project focuses on the history of Portland's black community, the history of the Portland Police Bureau, and the relationship between the two. Starting with World War II and ending with Officer Sanford's public inquest in April 1975, this thesis showcases the determination of Portland's black activist community and the city's continued denial of culpability for police actions. Despite the inquest's results, Johnson's death and the advocacy surrounding the incident fueled the motivations of activists at both the national and state level, and encouraged the city to acknowledge the wrongdoings of the Bureau. 


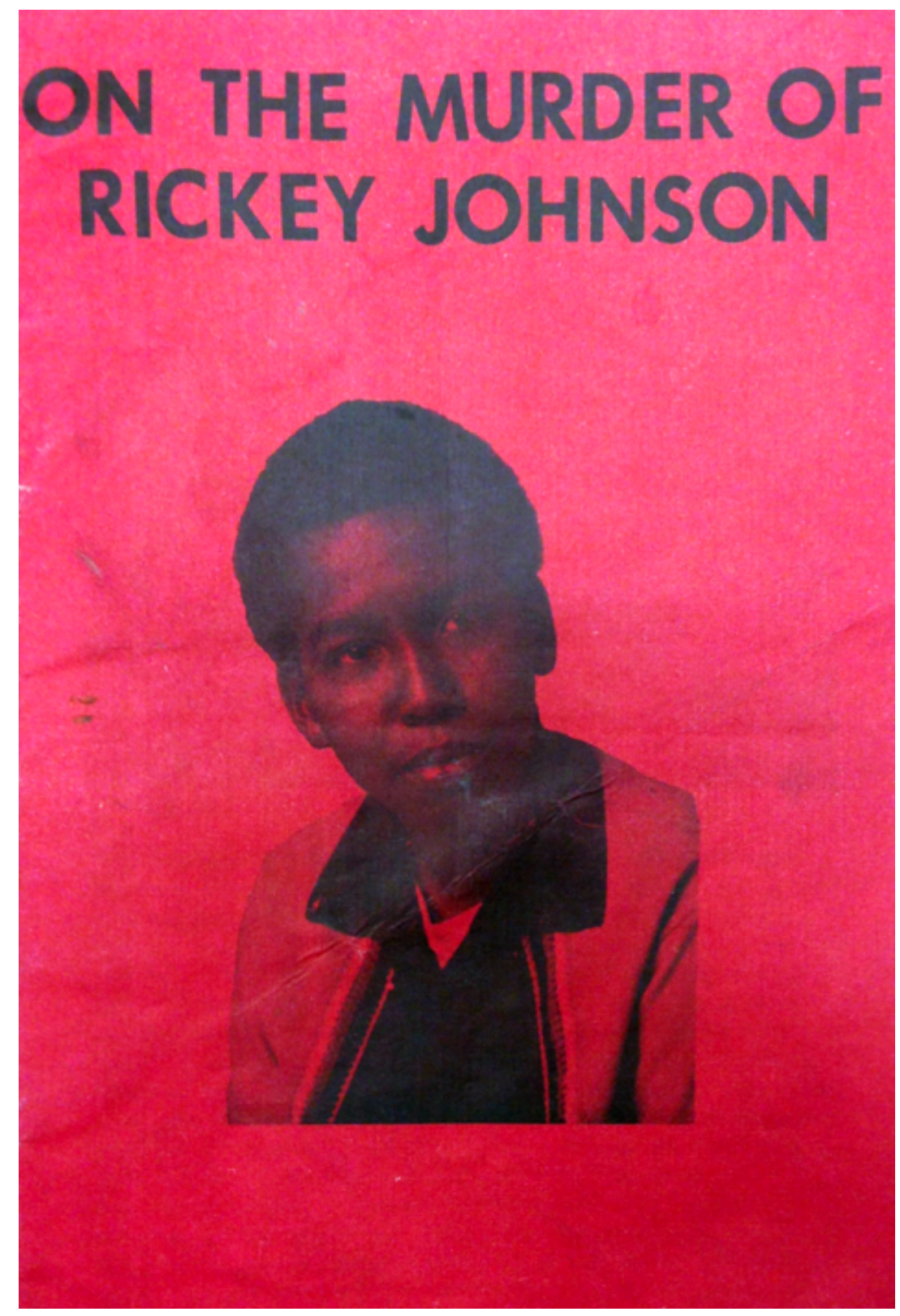

Figure 1: Zine circulated by Lucien Loiseau after Rickie Johnson's death. Source: Lucien Loiseau, "On the Murder of Rickey Johnson," 1975, Verdell Burdine and Otto G. Rutherford Family Collection, 1900-1980, in Box 7, Portland State University Special Collections and University Archives. 


\section{$\underline{\text { Dedication }}$}

For Rickie Charles Johnson. May your story—and stories so similar—always be told. 


\section{$\underline{\text { Acknowledgements }}$}

To the people who first encouraged me to go back to school and get a Master's in History—my parents, Jon and Priscilla. Throughout my youth my mom and dad encouraged a tenacious love of reading and for that I am thankful. Without their endless encouragement and support this degree and thesis could not have been completed. Another thanks to my older brother Sam, whose writing gumption and expertise I admire and to my little brother Caleb for always showing enthusiasm in my work.

Thanks to my partner Kevin for his support throughout this endeavor. For always giving me the appropriate space to study and work while simultaneously always making sure I ate dinner. I'm thankful for his unyielding listening skills as I admittedly "beat a dead horse" and for his consistently positive attitude.

To my historian comrades Taylor Rose, Jenna Barganski, Taylor Bailey, Tanya Monthey, Ryan Wisnor, Melissa Lang and Dave Hedberg, to name a few, for their commiseration, line edits, ideas, and enthusiasm. Most of all, for their friendship.

Thank you to the faculty at Portland State University—specifically David Johnson, Marc Rodriguez, Patricia Schechter and Darrell Millner-for their advice and expertise.

A special thanks to community members Baruti Artharee, Charlotte Rutherford, Joyce Harris, and Ray Tercek for their willingness to share personal experiences for this project. The discussions I had were invaluable and helped guide my wandering ship of a thesis.

Lastly, a thanks to you for reading. 
Table of Contents

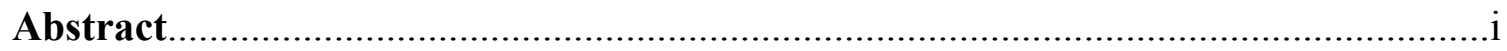

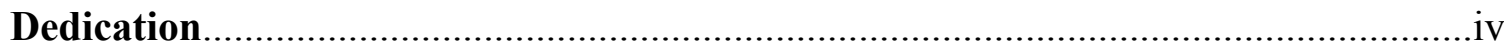

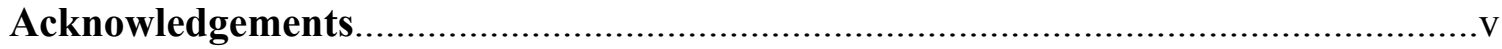

List of Figures .............................................................................................

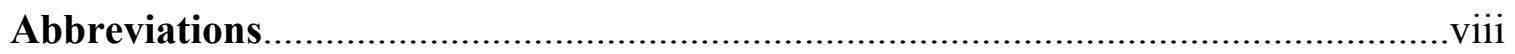

Introduction

On the Murder of Rickie Johnson................................................................................ 1

Chapter One

The history of policing Portland's black community .....................................................14

Chapter Two

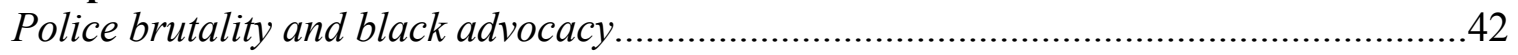

Chapter Three

Multnomah County's first public inquest................................................................ 70

Conclusion

The legacy of Rickie Johnson's death.........................................................................92

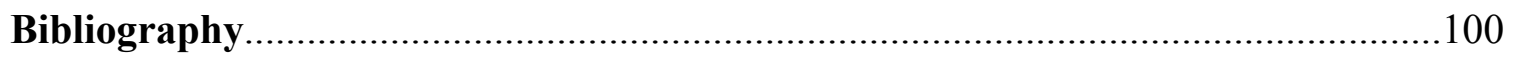




\section{List of Figures}

Figure 1: Zine by Lucien Loiseau entitled, “On the Murder of Rickie Johnson”...............iv

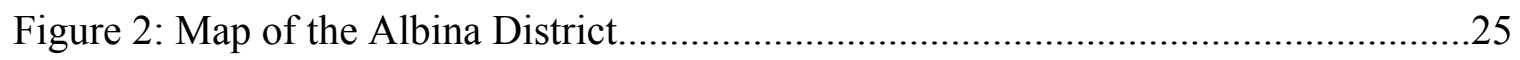

Figure 3: Picture of Joseph Hopkins, a victim of police brutality.................................39

Figure 4:Victims Charles Menefee and Kenneth Allen as distributed in The Oregonian.40

Figure 5: A sketch of the night of March 14, 1975 from The Oregonian........................45

Figure 6: Charlotte Rutherford speaking at the march on the police station...................53

Figure 7: Charlotte Rutherford and Baruti Artharee of the Black Justice Committee at a press conference following the march on the police station.......................................55

Figure 8: Kent Ford of the Black Panther Party in an argument with a deputy at the

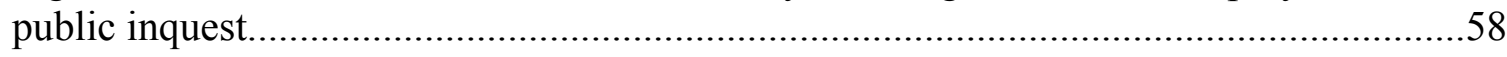

Figure 9: Black Coalition members list...............................................................62

Figure 10: The family of Rickie Johnson at Sanford's public inquest...........................83 


\section{Abbreviations:}

AMA: Albina Ministerial Alliance

BJC: Black Justice Committee

LCRM: Long Civil Rights Movement

NAACP: National Association of Colored People

PARC: Portland Archives and Records Center

PPA: Portland Police Association

PPB: Portland Police Bureau 


\section{$\underline{\text { Introduction }}$}

\section{The Murder of Rickie Johnson and Police Brutality in Portland, Oregon}

On March 14, 1975, Radio Cab driver Martin Zamzow received a request to deliver fourteen dollars worth of Chinese food to a house on North Gantenbein Avenue in Portland, Oregon. A relatively regular request for the time, Zamzow normally would have delivered the food without thinking twice. However, two nights prior on March 12, Zamzow received the exact same request to be delivered to the same abandoned house on North Gantenbein Avenue. When he arrived at the house on March 12, two youth robbed him at gunpoint. When Zamzow received the exact same request on March 14, he did not want to risk a second robbery so he called the Portland Police Bureau (PPB).

The PPB sent Officer Kenneth Sanford inside the house to investigate. A sevenyear veteran of the Bureau, Sanford worked in the North Portland area and investigated the robbery at the house two nights prior. The PPB also decided to catch the perpetrators in an unconventional sting operation. Sanford dressed in a radio cab uniform provided by cab driver Zamzow and drove a Radio Cab to the house in North Portland. Before approaching the house, Sanford found an empty box of to-go food in a garbage can nearby. Sanford approached the house dressed as a Radio Cab driver carrying an empty box of to-go food. Inside the box was a loaded gun. ${ }^{1}$

Upon his arrival, sixteen-year-old Homer Zachery opened the door and invited Sanford in. Once Sanford was in the house, seventeen-year-old Rickie Charles Johnson pointed a gun at Sanford and said, "Give me all your money or I'll blow your head off."2

\footnotetext{
1 "Police Killing Justified, Black Juror Disagrees," The Portland Observer, April 3, 1975.

2 "NAACP Requests Inquest into Shooting Death," The Oregonian, March 20, 1975; Jim Hill, "Blacks to
} 
Sanford revealed his own gun from the to-go box and told Johnson and Zachery to freeze and to drop their weapons. What happened next was originally disputed; Sanford claimed Johnson turned and crouched in preparation to shoot, so Sanford fired two shots at him. The first bullet lodged in the wall behind Johnson, and the second hit him in the back of the head. Johnson died instantly. After Zachery witnessed the shooting, he ran out the back door and into the backyard, where Sanford fired three shots at him. None of the bullets hit Zachery, but he quickly surrendered and the police arrested him.

While Sanford claimed he shot Johnson in self-defense, evidence suggested otherwise. The investigators on the scene found Johnson's gun in the living room but his body fen feet away in the dining room. ${ }^{3}$ This evidence suggested that instead of crouching in preparation to shoot like Sanford reported, Johnson actually dropped his gun in the living room and ran through the dining room toward the back door. This meant that Officer Sanford shot and killed seventeen-year-old Rickie Charles Johnson in the back of the head as he attempted to flee.

News of Johnson's death spread quickly throughout Portland, and the city's black community reacted with anger. Not only did the circumstances of the shooting suggest that Johnson had been murdered, the incident marked the fourth killing of a black man in Portland in a five-month period. ${ }^{4}$ This string of violence that occurred between October

Seek Shooting Inquest," The Oregonian, 22 1975; Alan Hayakawa, "Black Groups Granted Inquiry into Police Shootings," The Oregonian, March 23, 1975, sec. Editorials.

${ }^{3}$ Lucien Loiseau, "On the Murder of Rickie Johnson," 1975, In Box 7, Verdell Burdine and Otto G.

Rutherford Family Collection, 1900-1980, Portland State University Special Collections and University Archives.

${ }^{4}$ Ibid; "Black Student Union in the Black Community," Ujima 1, no. 3 (Spring 1975), in Box 7, Verdell Burdine and Otto G. Rutherford Family Collection, 1900-1980, Portland State University Special Collections and University Archives; Karen Gibson, "Bleeding Albina: A History of Community Disinvestment, 1940-2000," Transforming Anthropology 15, no. 1 (2007): 3-25. This is similar to Oakland, 
1974 and March 1975 incentivized Portland's black activist community to speak out against police brutality and question the culpability of the PPB. Johnson's death by Officer Sanford acted as a tipping point for a new generation of activists that resulted in the widespread acknowledgement of officer wrongdoing against Portland's communities of color.

Johnson's death by Sanford elicited varied responses from the white majority in Portland. Some citizens familiar with Portland police misbehavior could not believe the rampant rate at which police officers brutalized black citizens. Other white citizens supported Sanford's action and felt no sympathy toward Johnson and his family. These Portlanders claimed Johnson was another criminal that deserved to be reprimanded for breaking the law. This opinion perpetuated the "Criminalblackman" stereotype. The "Criminalblackman," a term coined by criminologist Katheryn Russell Brown, is the belief that all black men are criminals, and all criminals are black men. ${ }^{5}$ The idea of a "Criminalblackman" justified the over policing of black communities nationwide and desensitized a large portion of Portland's white citizenry to the abuse of African Americans by white people in power. ${ }^{6}$

The idea of the "Criminalblackman" dates back to the late nineteenth century. In 1884, Harvard scientist Nathaniel Shaler described black criminality as rampant and uncontrollable and firmly believed that no other nation had a "difficulty as great as

California's experiences post WWII as well. Historian Robert Self argues that the black freedom struggle was linked with the postwar transformation of U.S. cities and suburbs nationwide. See Robert Self, American Babylon: Race and the Struggle for Postwar Oakland, (Princeton: Princeton University Press: 2003).

${ }^{5}$ Katheryn Russell-Brown, The Color of Crime: Racial Hoaxes, White Fear, Black Protectionism, Police Harassment, and Other Macroaggressions (New York: New York University Press, 1999).

${ }^{6}$ Ibid. 
America's Negro problem." ${ }^{, 7}$ Social scientists began to rely on skewed crime statistics to justify continued racial segregation, repression and disenfranchisement. These scientists synthesized the statistics in a way that demonized African American crime while simultaneously excused white crime as anomalous or situational. Utilizing biased statistics to justify black criminality emerged during this time as a methodological way to prove black inferiority. ${ }^{8}$ This lead to an increase in black arrests, over policing and police brutality nationwide. Historian Khalil Muhammad describes black criminality during this time as an "intellectual defense of lynching, colonial style criminal justice practices, and genocide." 9

By the New Deal and Progressive Era, white social scientists and reformers reified this false narrative by emphasizing black criminals as perpetrators of a vicious criminal cycle within their own communities. White criminals, however, were seen as victims of industrialization and in need of government aid. Therefore, government agencies installed programs throughout the Progressive Era to help poor whites achieve upward mobility. The majority of these programs, including local YMCA, playground managers, and recreation centers, barred black citizens from participation based on the color of their skin. ${ }^{10}$ The New Deal efforts by reformers purposefully denied aid to black people and were meant to propel white immigrant communities while repressing poor black communities. ${ }^{11}$ These shady New Deal efforts were transparent to some; a group of

\footnotetext{
${ }^{7}$ Khalil Gibran Muhammed, The Condemnation of Blackness: Race, Crime, and the Making of Modern Urban America (Cambridge: Harvard University Press, 2010).

${ }^{8}$ Muhammed, The Condemnation of Blackness.

${ }^{9}$ Ibid.

${ }^{10}$ Ibid.

${ }^{11}$ Ibid; Heather Ann Thompson, "Why Mass Incarceration Matters: Rethinkin Crisis, Decline and
} 
sociologists as early as the 1920 s argued that instead of a crime problem, black neighborhoods experienced a problem with over policing and racial targetization. ${ }^{12}$

Black criminalization continued throughout the postwar era, and the criminal justice system evolved exponentially between WWII and the 1960s. ${ }^{13}$ Historian Leonard Moore concluded that officers policing black neighborhoods in the postwar years adopted a mentality of "us versus them" and targeted black people for harassment and brutality. ${ }^{14}$ The Communist party actually referred to police brutality in New York City post WWII simply as "lynching, Northern style." ${ }^{, 15}$ After WWII, cities nationwide witnessed a mass exodus of middle class whites to the suburbs. As white citizens moved out of the city, urban police units utilized brutality efforts to control the urban black and poor working class still living within city limits. ${ }^{16}$ These urban police units became the protectors of white privilege and the challengers of black mobilization. ${ }^{17}$ The nearly all white force that policed black urban neighborhoods became an inescapable entity for black residents.

Instances of police brutality, although not new, skyrocketed in the postwar era due to the mass segregation of urban spaces and the increase in the idea of black criminality. ${ }^{18}$ Due to this idea of black criminalization, the 1950s and 1960s witnessed a huge influx in

Transformation in Postwar American History," The Journal of American History 97, no. 3 (December 2010): 703-34.

${ }^{12}$ Patricia Schechter, "Ida B. Wells-Barnett and the Carceral State" (History Faculty Publications and Presentations, Portland State University, 2012), http://pdxscholar.library.pdx.edu/hist_fac/16.

${ }^{13}$ Simon Ezra Balto, “'Occupied Territory': Police Repression and Black Resistance in Postwar Milwuakee, 1950-1968," The Journal of African American History 98, no. 2 (Spring 2013): 229-52.

${ }^{14}$ Ibid.

${ }^{15}$ Taylor, "Race, Class and Police Brutality in New York City"

${ }^{16}$ Leonard Moore, Black Rage in New Orleans: Police Brutality and African American Activism from World War II to Hurricane Katrina (Baton Rouge: Louisiana State University Press, 2010).

${ }^{17}$ Balto, "“Occupied Territory."”

${ }^{18}$ Ibid. 
policing in urban schools, work and leisure spaces. ${ }^{19}$ This over policing, however, did not lead to greater protection of black neighborhoods. Instead, white police officers saw black neighborhoods as areas that deserved constant surveillance and promoted the idea of the "Criminalblackman" who needed constant intervention in daily matters. ${ }^{20}$

At the turn of the twentieth century, single black women were often accused of fabricated crimes. Historian Cheryl Hicks explains that these charges were made up to further perpetuate the idea that the unmarried black woman was a social pariah and dangerous to everyday society. ${ }^{21}$ Similarly, many of the so-called crimes committed by black citizens throughout the 1960s were, in fact, not crimes at all. Police departments illegalized minor offenses within black communities—-such as loitering or talking in a group of two or more in a public space - to demonize the actions of black citizens. ${ }^{22}$ Throughout the 1960s, President Lyndon B. Johnson's administration maintained a severe anti urban crime ideology. His rhetoric inflicted fear upon people throughout the decade and encouraged the belief that crime ran rampant in urban areas. By 1965, law enforcement agencies in cities nationwide received an increase in funds and equipment when they demonstrated the prevalence of crime in their community. These bureaus created new methods of counting and defining crime, which distorted crime rates within black communities throughout the $1960 \mathrm{~s}$ and $1970 \mathrm{~s} .{ }^{23}$ Citizens falsely believed that the national crime rate was increasing and that black urban areas had much to do with it.

\footnotetext{
${ }^{19}$ Thompson, "Why Mass Incarceration Matters."

${ }^{20}$ Russell-Brown, The Color of Crime.

${ }^{21}$ Cheryl Hicks, Talk With You Like a Woman: African American Women, Justice, and Reform in New York, 1890 - 1935 (Chapel Hill, N.C.: University of North Carolina Press, 2010).

22 Balto, "'Occupied Territory.",

${ }^{23}$ Thompson, "Why Mass Incarceration Matters."
} 
By Rickie Johnson's death in 1975, the idea of black crime as an uncontrollable societal hazard had been deeply imbedded in most of white America due to the past 100 years of racist rhetoric. This idea created huge obstacles for black activists who attempted to reform police agencies throughout the 1970s, as the white majority in cities nationwide believed these crime statistics to be true. Like the experiences of many black communities in the United States, African Americans in Portland had long suffered from widespread racial discrimination. Historian Elizabeth McLagan explains that:

Black people [in Portland] were regularly refused admission to restaurants, theaters, and hotels. Medical care was difficult to obtain, unions barred blacks from membership, employment practices confined them to certain jobs and integrated housing was resisted... according to a long-time black resident, 'Oregon was a klan state... a hell-hole. ${ }^{24}$

Cities such as New York, New Orleans, Detroit, and Los Angeles—which had large and well-established African American populations-experienced similar issues of repressive policing throughout the twentieth century. However, Portland's small black population made the struggle against police brutality more difficult due to limited allies in local government and a lack of visibility within the community. ${ }^{25}$ Largely recognized as a "progressive" city by residents and non-residents alike, outsiders may assume Portland promotes tranquility and peace between citizens and police officials. In a place that a writer for The Atlantic described as "The Whitest City in America," allegations of progressivism may be true for middle class whites. But Portland's communities of color have had very different experiences. ${ }^{26}$ Rather than seeing the city as a center of

\footnotetext{
${ }^{24}$ Elizabeth McLagan, A Peculiar Paradise: A History of Blacks in Oregon (Portland, OR: Georgian Press, 1980); Quintard Taylor, In Search of the Racial Frontier (New York: W. W. Norton \& Company, 1994).

${ }^{25}$ Brice Herrington, Black Crime: A Police View (Washington DC: Joint Center for Political Studies, 1977).

${ }^{26}$ Alana Semuels, "The Racist history of Portland, the Whitest City in America," The Atlantic, July 22,
} 
progressivism, Portland's black community saw the city as a repressive agent that promoted unjust police activity within the black community (synonymously referred to as Albina). ${ }^{27}$ Henry Stevenson, an African American WWII veteran who moved to Portland in 1960, described his experience:

Living in Portland at that time was almost like living in Alabama... black folks had it rough... the system, especially the police had a whole lot of feet on black peoples' necks... it was nothing for a cop to just shoot a brother... when this did happen, there was no consequences... the cops weren't afraid of being reprimanded in any way. ${ }^{28}$

Portland police officers were unafraid of being held accountable because punishment was rarely sought. Throughout Portland's history, black citizens decried the PPB's unassailability and unaccountability in the face of hundreds instances of police brutality, harassment, and inappropriate activity against African Americans. For most of its existence as an urban area, people of color in Portland have faced housing and employment discrimination and police harassment. One resident reflecting upon this history remarked, "Portland was a racist city but the thing that made Portland unique was that we were in total denial that there was any racism..29

Due to the traditional narrative of the Civil Rights Movement, the 1970s are often remembered as the still period after the tumultuous 1960s. In actuality, the decade was a time of important change in urban America. Historian Bruce Shulman notes that "most Americans regard the Seventies... as eminently forgettable... an era of bad clothes, bad

2016.

${ }^{27}$ Gibson, "Bleeding Albina."

${ }^{28}$ Lucas Burke and Judson Jeffries, The Portland Black Panthers (Seattle: University of Washington Press, 2016): 39 .

${ }^{29}$ Burke and Jeffries, The Portland Black Panthers. 
hair, and bad music impossible to take seriously. ${ }^{, 30}$ In reality, Shulman argues, the 1970s acted as an incubator for radical societal movements that pushed for women's rights, gay rights, and the rights of people of color. Shulman contends, "The strains of "We Shall Overcome" were displaced by cries of "Burn, Baby, Burn" as activists moved from the peaceful protests of the 1960s to more radical methods in the 1970s. ${ }^{31}$ Police nationwide responded to militant activism among radical groups by bolstering surveillance techniques and increasingly using force as a method of control. Increased surveillance heightened social tensions, which in turn increased the amount of violent incidents with police officers. Despite the large number of deaths committed by police in the 1970s, the United States court system would only indict one in five hundred officers involved in police shootings nationally. ${ }^{32}$

Similarly, the classical narrative of the Civil Rights Movement focuses on black male activist efforts during the 1950s and the 1960s starting with Brown vs Board of Education in 1954 and ending with the Voting Rights Bill of 1965. However, historian Jacquelyn Dowd Hall argues the naivete of this restrictive remembrance, and instead argues for the temporal, gender and spatial expansion of what she calls the Long Civil Rights Movement (LCRM). The LCRM expands black mobilization efforts from the New Deal era of the 1930s to the late 1970s and includes cities across the United States. By temporally and spatially expanding the narrative, the struggle for civil rights is portrayed as a more diverse and evolving social mobilization movement. The story of Rickie

\footnotetext{
${ }^{30}$ Simon Hall, "Protest Movements in the 1970s: The Long 1960s," Journal of Contemporary History 43, no. 4 (2008): 655-72.

${ }^{31}$ Ibid.

${ }^{32}$ Carl Klockars, "A Theory of Excessive Force and Its Control," in Police Violence (New Haven: Yale University Press, 1996): 7.
} 
Johnson's death and the advocacy surrounding these events aid in the spatial and temporal expansion of the traditional narrative of the Civil Rights Movement and supports Hall's theory of the LCRM. ${ }^{33}$

The LCRM is especially important to Portland history. Due to its limited black population and seemingly liberal and progressive city government and culture, citizens often resist the idea that Portland has encountered race relation issues similar to that nationwide. Realistically, Portland has played host to instances of police brutality against its communities of color since the establishment of the bureau. By studying Portland's advocacy efforts against the PPB, we can get a clearer picture of where Portland has been and where it should be headed.

Historian Leonard Moore defines police brutality in America as "all encompassing" and including:

Unlawful arrests; assaults, threatening and abusive language; the use of racial slurs; sexual exploitation; the beating of prisoners in police custody; racial profiling; police complicity in drug-dealing, prostitution, burglaries, protection schemes; and the lack of justice available to black defendants in the courts. ${ }^{34}$

Decades of repression, suppression and surveillance both locally and nationally brought Portland's police brutality issue to a head in the spring of 1975 with Rickie Johnson's death. African Americans in Portland worried that the slew of deaths was indicative of a larger and longer pattern of civil rights injustices by Portland police. Johnson's death incentivized anti-police brutality advocacy and led to Multnomah County's first public

\footnotetext{
${ }^{33}$ Jacquelyn Dowd Hall, "The Long Civil Rights Movement and the Political Uses of the Past," The Journal of American History 91, no. 4 (March 2005): 1233-63; Brian Purnell, "Freedom North Studies, the Long Civil Rights Movement, and Twentieth-Century Liberalism in American Cities," Journal of Urban History, March 2016; Taylor, In Search of the Racial Frontier.

${ }^{34}$ Moore, Black Rage in New Orleans.
} 
inquest.

Historians Beth Bailey and David Farber describe the mid 1970s as a time of “economic transformation, reconfigurations of identity, and cultural uncertainty," yet those who struggled against injustice in Portland had a distinct focus and a cause. ${ }^{35}$ This thesis seeks to unravel the untold story surrounding Johnson's death, which includes black advocacy efforts, police power, and the city's culpability in allowing the PPB to operate with impunity in the black community. The death of Rickie Johnson gave rise to a sustained social movement that raised serious questions about the nature of police oversight, accountability, and brutality in Portland's Albina community.

This thesis begins by exploring thirty years of Portland racial and civil rights history as it relates to the issue of policing and police reform. Beginning with the onset of WWII, the first chapter explores the simultaneous large-scale migration of black citizens to Portland and the establishment of Portland's police union, the Portland Police Association (PPA) during the World War II era. This chapter also details the PPB's history of policing in Albina and the various ways in which the PPA protected its members throughout numerous scandals and abuses that occurred throughout the postWorld War II period. These instances spanned generations and fueled the activism behind Johnson's death.

Chapter Two details the night of March 14, 1975, and the controversial circumstances surrounding the event. The community believed the Police Bureau had handled the situation poorly, as Johnson was shot in the back of the head while running

\footnotetext{
${ }^{35}$ Beth Bailey and David Farber, "Introduction," in America in the Seventies (Lawrence, Kansas: University Press of Kansas, 2004).
} 
away. The shooting gave rise to a social movement for reform among African American activists in Portland. This activism and advocacy is the focal point of the second chapter, and persuaded the city of Portland to host its first public inquest.

Chapter Three highlights Multnomah County's first public inquest. In response to Johnson's death, activists demanded that Portland's District Attorney Harl Haas host a public inquest to explore the facts surrounding the shooting. Black activists and city officials believed a public inquest would provide information on Johnson's death to the public. Activists hoped this public inquest would hold officers accountable for their actions. The third chapter also discusses the African American community and city government response to Sanford's public inquest trial and the city's responsibility in police behaviors.

Although white residents have heralded the city of Portland for its livability and progressive nature in recent years, needs of the city's minority communities have often fallen on deaf ears. In November 2016, Portland Mayor Charlie Hales said in personal correspondence with a resident that Portland's involvement in the popular Black Lives Matter Movement was turning a "national issue into a local issue," insinuating that Portland's history was free of issues of police brutality and abuse. ${ }^{36}$ Like many white Portlanders, Hales seemed unaware of the longstanding and recent history of policing within the city's black communities. In May 2010 three PPB officers shot and killed twenty-five-year-old Keaton Otis. Otis suffered from paranoid delusions, depression, and other forms of mental illness. While driving in Northeast Portland, police pulled Otis

\footnotetext{
${ }^{36}$ Charlie Hales (former Portland mayor) in discussion with NAACP secretary Melissa Lang.
} 
over for not using his turn signal, but officers also admitted that they believed the 6'4" black male "looked suspicious." In a confusing episode following this minor legal infraction, PPB officers shot Otis thirty-seven times after he apparently pulled out a gun. He died on the scene. Local reporters Anna Griffin and Casey Parks stated: "Police reform activists were incensed, but not shocked, by Otis's death... Otis was in the midst of a mental crisis. No matter. Pull a gun on police officers, and they are legally entitled to respond with maximum force." ${ }^{37}$ The overwhelming and seemingly unnecessary use of force by Portland police officers against Otis in 2010 demonstrates how the issue of police brutality against people of color has remained a significant issue for the city long after Johnson's death.

Rickie Johnson's death is an important moment in Portland history that has largely been overlooked in discussions of Oregon's history. Johnson's death reflects the shifting attitudes in advocacy during the 1970s, and the relationship between Portland's black community, the Police Bureau, city government, and the larger white community. The death of Rickie Johnson and the police brutality, suppression and controversy discussed throughout this thesis show how those without a historical framework of understanding — including former Mayor Charlie Hales—are wrong to exclude Portland from the national history of police brutality in the United States.

\footnotetext{
${ }^{37}$ Anna Griffin and Casey Parks, "Keaton Otis: Race Mental Illness and a City's Lost Son," Oregon Live, August 4, 2014, http://www.oregonlive.com/keaton-otis/. It has been disputed whether or not Otis actually had a gun. Officers claimed he pulled the gun on them before they began to shoot and claimed Otis shot an officer in the leg. However, activists argue that the police never brought the gun into evidence, and that Otis was not known to even own a gun. Some suggest an officer accidentally shot his fellow officer and that is how he was injured.
} 


\section{Chapter One}

\section{The history of policing Portland's black community}

"Police atrocities are nothing new, but they must not be allowed to go on unchecked." - Portland Observer, March 27, $1975^{1}$

Throughout Portland's history, black residents have shared experiences that

transcend generations. In 1922, Oregon voters elected Governor Walter Pierce, who was

a card carrying member of the Ku Klux Klan. Additionally, Pierce had the support of the Klan throughout his campaign. ${ }^{2}$ In 1925, Portland black resident Lee C. Anderson

observed, "We are surrounded by a prejudice which you do not find in our neighboring states."3 Forty-five years later in 1967, Portland government officials still were discriminating against the city's black citizens. A young man commented to the local newspaper, "Where else but Albina do cops hang around streets and parks all day like plantation overseers?"4 These experiences span decades in which black citizens in Portland experienced brutality at the hands of local government and law enforcement.

The Portland Police Bureau (PPB) formed in 1870 with the Metropolitan Police Bill. $^{5}$ By 1960, the PPB had established itself as a powerful force for safety and stability

\footnotetext{
1 "Black Students Protest Killing," Portland Observer.

${ }^{2}$ William G. Robbins, "Walter Pierce (1861-1954)," The Oregon Encyclopedia, January 21, 2016, https://oregonencyclopedia.org/articles/pierce_walter_1861_1954_/\#.WbaphkqGPqR; Semuels, "The Racist History of Portland, the Whitest City in America."

${ }^{3}$ Kimberly Mangum, A Force For Change, Oregon State University Press: Corvallis, 2010.

${ }^{4}$ Santi Elijah Holley, “'Burn the Town Down': The Striking Similarities Between Portland's 1967 Race Riot and Our City's Current Relationship with People of Color," The Portland Mercury, June 21, 2017, http://www.portlandmercury.com/feature/2017/06/21/19105241/burn-the-town-down.

5 "History of the Portland Police Bureau | The City of Portland, Oregon," accessed November 3, 2015, http://www.portlandoregon.gov/police/40004; Stan Scotton, "A History of the Portland Police with Concentration from 1870-1932" (Portland State University, 1970), Oregon Historical Society. Oregon was to be a place for migrants coming from the eastern United States to establish themselves anew as white "pioneers." To this end, the Oregon Constitution prohibited minority populations from moving to the region. The Exclusion Laws of 1840 - 1860, also known as "The Black Laws," sought to create an exclusively white population in the state and set up a restrictive regime for African American migration.
} 
for white residents, and as an agent of oppression for minority populations. Sociologist Robert Staples describes the PPB throughout history as a "colonial" force that "acted as agents to enforce the status quo" and to "protect the property of the colonizers who live outside [black communities]." ${ }^{, 6}$ The Bureau focused their efforts on protecting property (largely owned by whites) within the black community and serving the white community while providing few benefits and little protection to Portland's black community. The PPB rarely protected the rights of Portland's black citizens yet they routinely tolerated vigilantism, union protection, organized crime and police brutality within the Bureau. ${ }^{7}$

During the 1940s, Portland's black community increased from just two thousand people to over twenty-two thousand people. Simultaneously, the PPB created the United States' first successful police union. So while Portland's black population increased, Portland's police force became emboldened and protected. During the 1950s, African Americans in Portland achieved varied civil rights victories, including the Public Accommodation Act of 1953, which illegalized discrimination in public spaces by private

\footnotetext{
Although The Oregon Constitution banned slavery in 1857, settlers wanted to create a white homeland where enslaved and free blacks alike were unwelcome. These apartheid style laws forbade blacks from moving to Portland and even after they were no longer lawful, created the impression that African Americans and other minorities were unwelcome, and supported a regime of police control defined by repression by state and city government officials. This mentality seeped into the culture of the Portland Police Bureau. For further discussion on how these arpetheid style laws affected the way in which officers police minority communities, see Charles Abbott Tracy's "Police Function in Portland, 1851-1874," Oregon Historical Quarterly, 80, 1. Abbott argues policing in Oregon originated as vigilante endeavors to protect private financial and personal investments. Ultimately, the first unofficial police forces in the Pacific Northwest aimed to "eliminate or reduce behavior that was detrimental to the success of important financial enterprises." Tracy argued that this privatized policing subsequently created a militarized force that was responsible for many of Oregon's policing issues throughout the twentieth century.

${ }^{6}$ Serbulo and Gibson, "Black and Blue," 9; Robert Staples, "White Racism, Black Crime, and American Justice: An Application of the Colonial Model to Explain Crime and Race," Phylon 36 (1975): 14-22. For further analysis of the Colonial Model in application to Oregon's pre-statehood police entity, see Charles Abbott Tracy's "Police Function in Portland, 1851-1874," Oregon Historical Quarterly, 80, 1.

${ }^{7}$ Charles Abbott Tracey, The Evolution of the Police Function in Portland, Oregon 1811-1874, (Berkeley: University of California Press, 1976).
} 
and public entities alike. Meanwhile, the PPB furthered their reputation as corrupt and vice ridden by participating in or turning a blind eye to organized crime. By the 1960s, the PPB implemented a "tough on crime" mentality and targeted Portland's black neighborhoods as areas of miscreant behavior. By adopting a "tough on crime" stance, the PPB saw a significant rise in police related shootings, and for those living in Portland's black community it seemed as if young men were dying in larger numbers year after year. Between October 1974 and March 1975, Portland Police officers shot and killed four black men who they claimed were involved in various crime related activities. The unarmed seventeen-year-old Rickie Johnson, who was shot by a Portland officer while attempting to flee, marked an important moment in this string of police violence. In his 1976 study of the PPB, historian Charles Abbott Tracey stated, "Police reform cannot become a reality until we begin to understand the nature of that which is being reformed." ${ }^{\prime 8}$ To better understand the significance of the death of Rickie Johnson, we must first examine and unpack the history of the PPB and its relationship to the black community. This chapter will detail the history of Portland policing and the history of the Portland's black community from WWII until 1975 and it will show how these two histories simultaneously interacted throughout time. Decades of questionable police behavior such as minority persecution, organized crime, and failed police modification instigated black citizens, activists and a large portion of white Portlanders to decry Rickie Johnson's death as unnecessary police brutality.

\footnotetext{
${ }^{8}$ Tracey, The Evolution of the Police Function in Portland, Oregon 1811-1874.
} 


\section{Establishing Portland's black community and Portland's police union: 1940-1960}

The Second World War brought immense changes to the diversity of Portland citizenry, the dynamics of the PPB, and the relationship between the two. After the attack on Pearl Harbor in December 1941, the United States entered WWII and immediately called for Americans nationwide to contribute to the war effort, including the production of liberty ships. ${ }^{9}$ Portland became a major shipbuilding center that produced thousands of liberty ships for the war effort. Shipyards recruited workers throughout the U.S. to work for the country's multiple sites, including Portland's Kaiser Shipyards and Commercial Iron Works. ${ }^{10}$ Between 1940 and 1944, Portland's metropolitan population increased from 501,000 to 661,000 with an African American population growth of nearly twenty thousand individuals - largely because of the various shipyards located on the outskirts of the city. ${ }^{11}$ Discrimination against African Americans existed prior to the war, but was not as intense as the discrimination experienced during the 1940s. Many white Portlanders assumed that an increase in black workers threatened their livelihood and privilege. African Americans in the city faced the brunt of this misplaced aggravation. ${ }^{12}$

Black migrant workers from the eastern United States expected to find more liberal attitudes toward race in the West, but instead they found that similar racial tensions and discrimination existed in Portland. Although African Americans made up a

\footnotetext{
9 "Area Defense on Full Time," The Oregonian, December 8, 1941.

10 "Kaiser Yards Launch Trio of Ships, Including Carrier," The Oregonian, November 23, 1943; "Vancouver Built Flattop Sunk in Recent sea Battle," The Oregonian, August 17, 1944; "U.S. Lease with the Port of Portland," September 11, 1944, The Port of Portland. This lease documents the contractual agreement between the United States and the Port of Portland. The Port leased the shipyard land to the United States government to aid in the shipbuilding industry for the war effort.

${ }^{11}$ Millner, "Blacks in Oregon"; Carl Abbott, Portland in Three Centuries, (Corvallis, OR: Oregon State University Press, 2011), 119.

${ }^{12}$ McLagan, A Peculiar Paradise, 145.
} 
substantial portion of the shipbuilding industry, they were denied multiple housing and job amenities; black citizens were limited to housing communities on the outskirts of the city such as Vanport or Guild's Lake and the largest shipyard union, The Boilermakers, denied memberships to black workers. ${ }^{13}$ Therefore, African Americans received the least skilled jobs in the yard, which left them vulnerable to layoffs and unemployment. ${ }^{14}$ In 1943, African American migration to Portland peaked and the city witnessed an increase in public accommodation discrimination, police harassment, and conflict between black workers and the Boilermakers Union who represented shipyard workers. ${ }^{15}$ Private housing for single black men and black families was scarce outside of Vanport, Guild's Lake and the small northeastern community of Albina, so many black workers were forced to reside in shipyard dormitories. In response, many white shipyard workers complained about sharing their living quarters with black coworkers. Neighborhood groups protested and barred blacks from moving into their areas, and City Commissioner J.E. Bennett advised Kaiser Shipyard owner Henry Kaiser to stop hiring black shipyard workers. ${ }^{16}$ Mayor Earl Riley believed African American migration to Portland "threatened Portland's regular way of life." ${ }^{17}$ Portland residents and elected officials seemed committed to maintaining their nearly lily white city.

Politicians in Portland believed black workers threatened Portland's cultural normality, so therefore pigeonholed black citizens into certain areas of work. Kathryn

\footnotetext{
${ }^{13}$ Millner, "Blacks in Oregon"; Abbott, Portland in Three Centuries, 123.

${ }^{14}$ Millner, "Blacks in Oregon."

${ }^{15}$ Abbott, Portland in Three Centuries, 123.

${ }^{16} \mathrm{Ibid}, 124$.

${ }^{17}$ Abbott, Portland in Three Centuries, 123.
} 
Hall Bogle, a longtime Portland black resident, commented on the lack of occupational opportunities for African Americans during wartime: "There were no black salespeople in town - not a one; there were no black elevator operators; there were no blacks visible in any business situation except those very few places where black people had established his own private business." ${ }^{18}$ In 1992, Bogle told the Oregon Historical Quarterly of the frequency in which Portland establishments denied service to her throughout the 1940s. While visiting a restaurant during WWII, Bogle remembered, "The waitress said they didn't want to serve me. Humiliated, I sat there while the others were having their coffee and chatting... that happened again and again at different places." ${ }^{.19}$ Bogle recollected that it was common to see a Portland establishment with a sign that read, "We serve white trade only." Additionally, union laws and discriminatory companies who refused to hire African Americans limited job prospects for blacks that migrated to Portland. Bogle further explained that many white citizens brushed off racial prejudices in Portland and excused them as wartime stress and tension. These white citizens argued that there were "greater things to worry about" than racist practices in Portland. ${ }^{20}$ African American residents such as Bogle, who confronted the pervasive racism in the Rose City, wholeheartedly disagreed. ${ }^{21}$

While the majority of blacks in Portland were denied union membership in the wartime shipyards, the PPB successfully mobilized and became the United State's first

\footnotetext{
${ }^{18}$ Kathryn Hall Bogle, "Kathryn Hall Bogle on the African-American Experience in Wartime Portland," Oregon Historical Quarterly, 93, 4 (Winter 1992-93): 395.

${ }^{19}$ Ibid.

${ }^{20}$ Ibid.

${ }^{21}$ Ibid.
} 
police union. ${ }^{22}$ By World War II, the city's thriving port economy necessitated a diverse, smart and skilled police force. In 1941, Police Chief Harry Niles installed a police science school, the first police training school in the U.S., and the first records division in the bureau's history. Many historians believe Niles responsible for the professionalism of the PPB because it mandated officers follow certain rules including fitness testing for officers and training on report writing. ${ }^{23}$ Ironically, Niles and his movements toward professionalization were largely responsible for the establishment of the Portland Police Association (PPA) union, as the men who formed the union did so to fight tedious bureaucratic tendencies that they felt Niles established. Sociologists George Kelling and Robert Kliesmet, who studied the unionization of police agencies and how the police professionalization movement motivated bureaus to unionize in the U.S during the 1960s, argue that the historic belief that police unions oppose professionalization is troublesome. ${ }^{24}$ The authors argue that what police reformers dubbed as "professionalization" was more of a shift toward bureaucratic tendencies, or "stronger lines of administrative control and oversight, extensive rules and simplification of work tasks." ${ }^{25}$ Officers of the PPB felt the brunt of this bureaucratic micromanaging and decided to act against it by establishing the PPA as a labor union. Many Portland police

\footnotetext{
${ }^{22}$ McLagan, A Peculiar Paradise, 79; Millner, "Blacks in Oregon"; The shipyards most popular and powerful union, the Boilermakers, barred blacks from joining the union; Frank Springer, "A History of the Portland Police Association" (Portland, OR, n.d.), Portland Police Museum. This history of Portland's police union claims the PPB established the first successful police union charter.

${ }^{23}$ Susan Hauser, Pickets, Pistols and Politics (Portland: Portland Police Association, 1996) 7. Prior to this professionalism, Chief Niles stated the only requirement to work for the PPB was "that a man have two legs and walk a beat... as a result, the uniform of a Portland police officer often was worn by the dregs of society."

${ }^{24}$ George Kelling and Robert Kliesmet, "Police Unions, Police Culture, and Police Abuse of Force," in Police Violence (New Haven: Yale University Press, 1996).

${ }^{25}$ Kelling and Kliesmet, "Police Unions, Police Culture, and Police Abuse of Force."
} 
officers saw Niles as a tyrant who, as PPA historian Susan Hauser described, would "sacrifice veteran police officers to his lofty ideals of police professionalism and selfless patriotism. ${ }^{26}$ Conversely, Niles believed in the potential greatness of the PPB and wanted to eliminate outdated practices and encourage a police system that changed with its community.

The PPA officially established itself as the first police union in $1942 .{ }^{27}$ Frank Singer, a former Portland police officer, remembered the circumstances surrounding the establishment of the PPA: "The union formed, as all others have been formed, when a group of men can stand so much pushing around and finally they get pushed too far.,28 After Pearl Harbor, the expectations of the police increased and harsh circumstances were thrust upon police officers. ${ }^{29}$ Singer emphasized that the Portland police recognized their wartime duty, yet felt their efforts were being abused. Officers in the near all white police force frequently complained that while African American shipyard workers were paid and housed, the majority white police force was vulnerable to overwork and underpay. ${ }^{30}$ Portland police did not understand the discrimination blacks faced in the shipbuilding industry and took the situation at face value. Shipyard companies paid most ship workers twice as much as those in the police force and provided their employees with housing,

\footnotetext{
${ }^{26}$ Hauser, Pickets, Pistols and Politics, 6; "Harry M. Niles," Portland Police Museum \& Historical Society, accessed December 1, 2015, http://www.portlandpolicemuseum.com/harry-m-niles.html.

${ }^{27}$ Sebastian Coco, "We're the Oldest," The Rap Sheet, October 1974; Springer, "A History of the Portland Police Association." Frank Springer was the partner of John D. Hayes, the officer responsible for organizing the Portland Police Association.

${ }^{28}$ Springer, "A History of the Portland Police Association."

29 "Area Defense on Full Time," The Oregonian, December 8, 1941; Springer, "A History of the Portland Police Association.”; Hauser, Pickets, Pistols and Politics, 9. Officers were assigned two twelve-hour shifts with all days off cancelled with no overtime compensation.

${ }^{30}$ Hauser, Pickets, Pistols and Politics, 8.
} 
benefits that police officers lacked. ${ }^{31}$

Despite previous police union failures nationwide, the PPA maintained high levels of police officer membership and held onto its status as a bargaining agent for the Bureau. ${ }^{32}$ Nearly twenty-five years after the first PPA meeting, Officer Singer asserted: "The first charter ever granted to a police union was received in May of 1942 and we have held it continuously since that date. ${ }^{, 33}$ At the time, the Portland community hesitated to support the new police union and believed that it was, as a writer for the Oregonian wrote, an "effort to benefit [police officers] and the service to which they are attached." ${ }^{34}$ Another article from The Oregonian in April 1942 discussed a community worry that the police would always be suspected of "greater loyalty to union than to official duty. ${ }^{, 35}$ However, as the PPA grew, the union focused on campaigns that would increase its legitimacy and bolster community support. Union President Otto Meiners helped organize similar unions in Salem, Spokane, Vancouver, San Francisco and Los Angeles. ${ }^{36}$ In 1945, the PPA requested that the House Committee on Un-American Activities of the U.S. House of Representatives investigate Hollywood film producers. The union felt that the high amount of recently released gangster movies might encourage criminal behavior in youths nationwide. The Portland community supported this endeavor, and the Oregon Journal editorialized: "It is reassuring to find an association, composed of police officers, taking a strong stand against all causes of youth's

\footnotetext{
31 Ibid.

${ }^{32}$ After the Boston Police Strike of 1919 and the bureau's failed attempts to unionize, police agencies nationwide did not attempt to unionize until WWII.

33 Springer, "A History of the Portland Police Association."

34 "Police Unions," The Oregonian, April 16, 1942.

35 Ibid.

${ }^{36}$ Springer, “A History of the Portland Police Association.”, 27.
} 
delinquency. Homes, churches, civic influences and ourselves, will wish to do no less. ${ }^{37}$ It was important for the PPA to gain the backing of the community, and supporting popular measures like investigations into Hollywood filmmakers allowed the PPA to gain more political power within white Portland homes.

The institutionalization of the PPA is an important moment in PPB history. The PPA proved to be one of the strongest police unions in the country. It succeeded in stabilizing wages, restricting hourly workweeks and demanding sick leave and paid vacations. However, as decades progressed, it became nearly impossible to punish officers for inappropriate behaviors due to the protection provided by the union. Prior to the establishment of the PPA, the Chief of Police routinely released officers from service. With the union installed, officers could petition the union's civil service board to rectify the situation and reinstate terminated officers. If an officer committed an injustice - such as participating in organized crime, prostitution, or racial discrimination - the Bureau seldom punished them. ${ }^{38}$ When Singer wrote his report on the Bureau in early 1970, he concluded: "Excluding the lost cause of getting back free bus transportation to and from work, the union has gained EVERY objective that it set out to get. Can any more be said for the union's effectiveness?"39 The PPA quickly became Portland's most powerful union organization with substantial political power within local government. The PPA endorsed specific political candidates via financial donations and provided manpower for political campaigns. Therefore, politicians protected the PPA and police bureau. This

\footnotetext{
37 "Police Unions," The Oregonian, 28; "Editorial," Oregon Journal, September 21, 1945.

${ }^{38}$ Steve Duin, "Reinstated with Back Pay," The Oregonian, February 27, 1997.

${ }^{39}$ Springer, "A History of the Portland Police Association."
} 
protection snowballed over time to what seemed like complete dominance over employment and disciplinary matters and encouraged a culture of officer resistance within the bureau.

While the PPA became a respected part of the trade union movement, its reputation within Portland's black community was less positive. Police did little to protect black communities in Vanport and Guild's Lake. In 1945 a black man was shot through the window of his bedroom in Guild's Lake by a PPB officer who assumed the man was someone they had a warrant out for. ${ }^{40}$ The man shot and killed, Ervin Jones, had no connection to the suspect and was asleep in his house with his wife, children and extended family when the officer killed him. The city held a coroner's inquest and the jury decided the police officers involved in the shooting were not guilty. No one was charged with the death. ${ }^{41}$

Relations between police officers and black citizens nationwide grew more and more contentious after WWII, as black communities witnessed pervasive repression and simultaneous negligence from local police. This was especially true in Portland, due to the rapid increase in the city's African American population and the limited diversity of the police force and overall city. After the war, African Americans in Portland continued to live in the community of Vanport, an area of the city built by Henry Kaiser for his firm's wartime shipyard workers. In the spring of 1948, a railroad line dike on the Columbia River broke and the resulting flood swept the entire town away in less than an

\footnotetext{
${ }^{40}$ J. D. Chandler, Murder \& Mayhem in Portland, Oregon (The History Press, 2013); "Inquest Jury Hears How Negro Died in Police Raid," The Oregonian, October 10, 1945.

${ }^{41}$ More on the death of Ervin Jones, a coroner's inquest, and a public inquest in Chapter Three.
} 
hour. ${ }^{42}$ African Americans living in Vanport were forced to move to the Albina neighborhood of Northeast Portland. This marked the onset of the ghettoization of Portland's black community in the Albina neighborhood. ${ }^{43}$ City officials favored this area as a black neighborhood due to the older and less desirable houses. ${ }^{44}$ Additionally, housing was unavailable to Portland's black community anywhere but the Albina neighborhood due to a real estate practice known as redlining. ${ }^{45}$ Redlining is a discriminatory practice where banks refuse loans or investments based on area demographics. ${ }^{46}$ Albina was a little less than four square miles with boundaries stretching from north to south from Northeast Columbia Boulevard to present day I-84, and east to west from First Ave to Mississippi Avenue. ${ }^{47}$ The near complete ghettoization and segregation of Portland's black community allowed for easy surveillance and harassment by local law enforcement. By the 1960s, four-fifths of Portland's fifteen thousand African Americans lived in a two and a half square mile area inside the Albina district. ${ }^{48}$

\footnotetext{
${ }^{42}$ Gibson, "Bleeding Albina"; Millner, "Blacks in Oregon"; Abbott, Portland in Three Centuries; Peter Shaw, "Why Aren't There More Black People in Oregon?," Portland Occupier, November 12, 2012, http://www.portlandoccupier.org/2012/11/28/why-arent-there-more-black-people-inoregon/\#sthash.vx5VAzLV.dpbs.

${ }^{43}$ Stuart McElderry, "Building a West Coast Ghetto: African-American Housing in Portland, 1910-1960," The Pacific Northwest Quarterly 92, no. 3 (Summer 2001): 137-48. The theory of "ghettoization" has roots in $A$ Ghetto Takes Shape by Kenneth Kusmer.

${ }^{44}$ Gibson, "Bleeding Albina."

45 Jewel Lansing, Portland: People, Politics, and Power, 1851-2001 (Corvallis: Oregon State University Press, 2003).

${ }^{46}$ Gibson, "Bleeding Albina." Sociologist John McKnight coined the term during the 1960s.

47 Joshua Joe Bryan, "Portland, Oregon's Long Hot Summers: Racial Unrest and Public Response, $1967-$ 1969" (Dissertations and Theses, Portland State University, 2013).

${ }^{48}$ Gibson, "Bleeding Albina."
} 


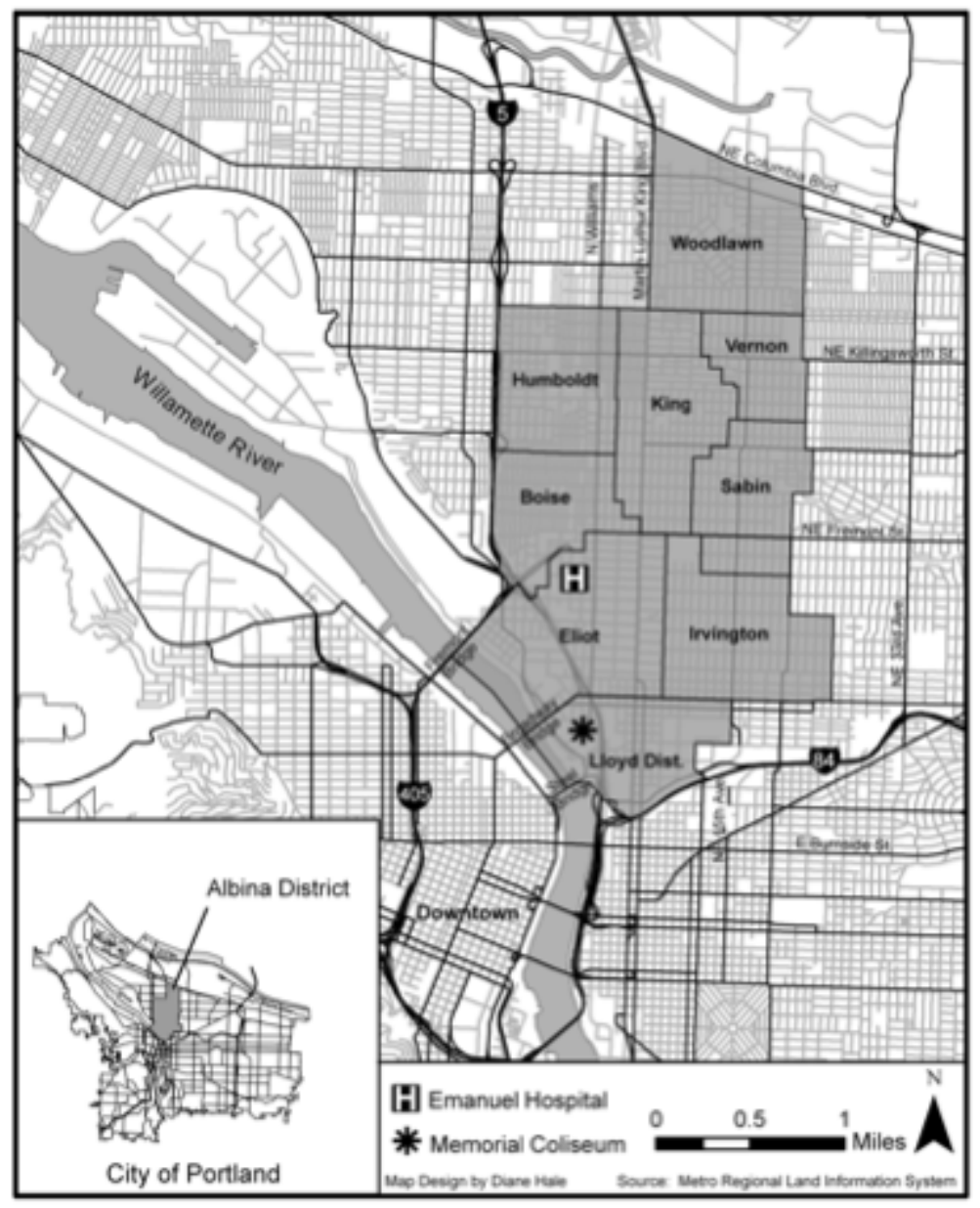

Figure 2: A map of the Albina district in Northeast Portland. Image source: Gibson, "Bleeding Albina."

Portland underwent radical transformations in government and society throughout the postwar period. The city matured and transitioned from a city government run by the "good-old boys" to a less nepotistic political climate. ${ }^{49}$ Postwar mayors such as Dorothy McCullough Lee championed anti-vice and "tough on crime" campaigns that promised Portland's citizens citywide safety and security. ${ }^{50}$ Despite various programs and political promises, black citizens continued to be repressed within the northern neighborhood of

\footnotetext{
${ }^{49}$ Lansing, Portland: People, Politics, and Power, 1851-2001.

${ }^{50}$ Ibid.
} 
Albina and mistreated through various public accommodations and city government entities. Additionally, the city's "tough on crime" attitude disseminated within the police department, as members of the bureau continued to be involved in organized crime.

Throughout the 1950s, Union Avenue in Northeast Portland became the heart of the Albina neighborhood. African Americans made up just two percent of Portland's overall population, but over eighty percent of Albina's population was black. A 1957 City Club of Portland Report titled "Report on the Negro in Portland: A Progress Report 1945-57" admitted: "It is the feeling of your committee that most white Portlanders are unaware of the social and economic problems which face the city's Negro population." ${ }^{\text {51 }}$ During the 1950s Portland's black community continued to fight for basic rights such as union representation, public desegregation, adequate public education facilities, and further housing opportunities. Until the passing of the Public Accommodation Act of 1953, which made discriminatory practices in public places illegal, Portland's black citizens were barred from nearly all Portland hospitals, restaurants, schools and public facilities. ${ }^{52}$ Within this segregated landscape, white elected officials displayed a total disregard of black community needs. With an "at large" electoral system for city government, even if they organized politically, the lack of neighborhood based candidates in Portland worked against giving a voice to African Americans. Portland remains one of the only cities to conduct at-large elections with many cities having

\footnotetext{
${ }^{51}$ City Club of Portland, "Report on the Negro in Portland: A Progress Report 1945-57" (Portland, April 19, 1957), http://ir.library.oregonstate.edu/xmlui/bitstream/handle/1957/12312/PortlandCityClubBulletinNegroPortlan d.pdf;jsessionid=5645BA30392F6311D62A88959519B893? sequence $=1$.

${ }^{52}$ Bryan, “Portland, Oregon's Long Hot Summers: Racial Unrest and Public Response, 1967-1969”; City Club of Portland, "Report on the Negro in Portland: A Progress Report 1945-57."
} 
abandoned the system under threat of lawsuits and civil rights actions under the Voting Rights Act. ${ }^{53}$ Portland quickly became the second most segregated city of the six major cities of the West Coast. ${ }^{54}$ Portland real estate and community disinvestment furthered segregation of the Albina community and encouraged Portland's police bureau to target black neighborhoods for vice activity and harassment.

While Portland's black community simultaneously experienced widespread housing segregation and the desegregation of public accommodations, members of the PPB aided further in the bureau's reputation as crime ridden. During the mid twentieth century, law enforcement officials received bribes and kickbacks from vice racketeers who ran unlicensed bars, brothels and gambling dens. ${ }^{55}$ Shortly after Mayor Lee's "tough on crime" campaign, the PPB and city government underwent a series of federal investigations that solidified Portland's reputation as a city of vice and dampened the reputation of the Portland police within a broader group of community members. Since the late nineteenth century, Portland had a reputation as a city that perpetuated vice through the support of law enforcement and local government. An established payoff system allowed prostitution, gambling, and illegal drinking. As long as the police received payoffs and criminal activity was confined to the northern and predominantly

\footnotetext{
${ }^{53}$ Brad Schmidt, "Limited Voting Rights: Portland's Electoral System Loses under California Law Aimed at Ensuring Minority Representation," Oregon Live, July 29, 2014, http://www.oregonlive.com/portland/index.ssf/2014/07/limited voting rights portland.html; Stephyn Quirke, "District Elections and Good Government," The Southeast Examiner, February 1, 2016; Thomas Buell Jr, "Portlanders Seek a City Hall Overhaul," Street Roots, July 6, 2016, http://news.streetroots.org/2016/07/06/portlanders-seek-city-hall-overhaul.

${ }^{54}$ Bryan, "Portland, Oregon's Long Hot Summers: Racial Unrest and Public Response, 1967-1969."

${ }^{55}$ Robert C. Donnelly, "Organizing Portland: Organized Crime, Municipal Corruption, and the Teamsters Union," Oregon Historical Quarterly 104, no. 3 (October 1, 2003): 334-65.
} 
black neighborhoods of Portland, city officials paid little attention to the corruption. ${ }^{56}$ Organized crime developed as Portland grew. Throughout the 1920s, city and state law officials cooperated with crime bosses and union racketeers to allow, benefit from, or ignore vice activities. ${ }^{57}$

By the mid 1940s, Berkeley Chief of Police August Vollmer had studied Portland's police bureau and reported that it was "overcostly, underproductive, poorly organized, inadequately supervised and underpaid." ${ }^{, 58}$ Vollmer argued that the activities of the Portland police cemented Portland's reputation as a "Wide Open City," with much of its vice activity and organized crime designated to Portland's segregated black neighborhood. Charles Pray, Portland Police Chief from 1949 to 1951, met harsh resistance from the bureau when battling Portland's police problems. Pray complained that "everybody at the police station seemed to know where gambling, was conducted" but he faced a wall of silence regarding vice activities "that were common knowledge." 59 It was apparent early on in the decade that Portland's police bureau was strongly embedded in and implicit in Portland's vice activity. By 1948, the City Club of Portland released a report that asserted prostitution and gambling had "been carried out openly and notoriously throughout the city of a period of several years past. ${ }^{, 60}$ Portland had become

\footnotetext{
${ }^{56}$ Bill Stanford, Portland Confidential (Portland: WestWinds Press, 2004).

${ }^{57}$ Donnelly, "Organizing Portland. With prohibition, the police arrested bootleggers who failed to make proper arrangements with the police. The bureau kept the confiscated booze in the basement of the police station. They were able to control the price of whiskey in the city based on the amount they released on the market. For further discussion, see Stanford, Portland Confidential.

${ }^{58}$ Lansing, Portland: People, Politics, and Power, 1851-2001.

${ }^{59}$ Ibid.

${ }^{60}$ City Club of Portland, "Law Enforcement in Portland and Multnomah County," February 20, 1948; The report counted over 248 places within the city where gambling, prostitution and vice were known to exist; Stanford, Portland Confidential, 24.
} 
a refuge for crime bosses with the consent of the police. ${ }^{61}$ Journalist Bill Stanford contends, "not every Portland cop participated in the payoff system-but it's clear the bureau was run by those who did. $" 62$

By 1954, teamsters and racketeers operated profitable gambling dens, brothels and unlicensed bars with support from Portland's police officers and the district attorney's office. ${ }^{63}$ Through wiretapping investigations, the Federal Bureau of Investigation (FBI) determined that Police Chief Jim Purcell and Mayor Fred Peterson were actively protecting vice operations. In 1956, Chief Purcell was indicted for “incompetence, delinquency and malfeasance in office." ${ }^{64}$ A grand jury determined that Purcell failed to control illegal activities such as gambling, bootlegging, prostitution and police bribery. From August 1956 to September 1957, three different Portland grand juries issued 115 indictments to Portland police officers. ${ }^{65}$ Fifty-nine of the original charges were dismissed. Due to the national publicity this incident received, Portland gained a reputation for being seedy, vice ridden and corrupt, and the city's police bureau similarly matched that description.

Although the racial issues related to police corruption were not part of the news story focused on corruption, African American residents of Portland knew first hand of the corruption within the police community because the police conducted much of this

${ }^{61}$ City Club of Portland, "Law Enforcement in Portland and Multnomah County."

${ }^{62}$ Stanford, Portland Confidential, 44.

${ }^{63}$ Donnelly, "Organizing Portland: Organized Crime, Municipal Corruption, and the Teamsters Union"; Stanford, Portland Confidential. Police Chief Jim Purcell was known city wide as Diamond Jim. This nickname was given to him due to his "dishonest" character. His closest friend was a pimp and accused grave robber named George Bernard. Bernard and Purcell operated and owned the vice ridden Penguin Club on Sandy Boulevard.

${ }^{64}$ Donnelly, "Organizing Portland."

${ }^{65} \mathrm{Ibid}$; Wallace Turner and William Lambert, "Hearings Set on Teamsters in Oregon," The Oregonian, December 6, 1956. 
vice activity in the northern black neighborhoods of Portland. Historians Serbulo and Gibson argue that the police preferred to suppress rather than protect blacks in Portland, which allowed vice and crime to flourish in black neighborhoods. ${ }^{66}$ Although this corrupt behavior began to be recognized and acknowledged by the larger, mainly white community, it did not completely taint their opinions of law enforcement and local government officials. ${ }^{67}$

The PPB enabled and encouraged a culture of corruption and resistance. The PPA provided officers with resources to protect their labor rights, but turned a blind eye to wrongdoing and supported the public view of an untouchable police bureau. This proved especially problematic and dangerous for Portland's black community, who were continually subjected to harassment by the officers of the PPB.

\section{From Repression to Revolt: Police Community Relations in Portland, 1960-1975}

Following the national investigation of vice activity in North Portland, the PPB and city government sought reform and department modernization. This created a new type of police force. The PPB vowed to be tough on crime and regain the support of the white community. During the 1960s, police officers nationwide — especially unionistscommitted themselves to a "crime fighting" ideology. ${ }^{68}$ Portland police officers and unionists participated in this "crime fighting ideology" that often unjustifiably targeted blacks and low-income whites. Karen Gibson and Diane Serbulo cite three reoccurring

\footnotetext{
${ }^{66}$ Serbulo and Gibson, "Black and Blue."

${ }^{67}$ Ibid; Donnelly, "Organizing Portland."

${ }^{68}$ Kelling and Kliesmet, "Police Unions, Police Culture, and Police Abuse of Force."
} 
complaints from the African American community against the PPB throughout the 1960s: police brutality, inadequate black representation within the police force, and insufficient civilian oversight of the individual officer. ${ }^{69}$ Throughout the 1960 s and early 1970 s, Portland's African American community felt the full force of the "tough on crime" ideology as the PPB, like bureaus nationwide, engaged in relentless surveillance and harassment of black activists. ${ }^{70}$

Among West Coast cities, Portland was second only to the metropolis of Los Angeles when it came to racial segregation. The nearly all white PPB patrolled the small neighborhood of Albina, which housed two-thirds of Portland's black community. Because much of the bootlegging, gambling and prostitution were pushed to North Portland, police officers targeted the Albina neighborhoods as a crime-ridden community that needed a tough clean up. ${ }^{71}$ Between 1960 and 1975 the Albina community witnessed intense police discrimination and violence. During the 1960s, forty-five percent of citizens arrested by the PPB were black, but African Americans made up less than five percent of Portland's overall population. ${ }^{72}$ By the mid 1970s, the Portland Police gained a less than favorable reputation within activist communities. The experiences of activist communities in the 1960s and early 1970s galvanized advocates against police brutality after Rickie Johnson's death in 1975.

Throughout the 1960s and early 1970s, police nationwide targeted black activists and anti-war advocates in local and national surveillance programs, which enabled the

\footnotetext{
${ }^{69}$ Gibson and Serbulo, "Black and Blue."

${ }^{70}$ Tracey, The Evolution of the Police Function in Portland, Oregon.

${ }^{71}$ Serbulo and Gibson, "Black and Blue."

${ }^{72}$ Ibid.
} 
harassment of black citizens by Portland police officers. In Kenneth Gervais' 1968 study

on the Portland Police Bureau, he reported that Portland officers stated that "political radicals, professional criminals, negroes... [and] civil rights groups" were in need of the highest police surveillance. ${ }^{73}$ The newly formed Portland Police Intelligence Division began monitoring activists in the Civil Rights Movement in the mid 1960s. Spying on political organizations was believed to be a legitimate police function during this time. ${ }^{74}$ The Intelligence Unit spied on black activists and used the gathered information to spread rumors that were meant to spark opposition from the community. ${ }^{75}$ Police often used irrelevant information to support their charges, and many of the targets were previous victims of police brutality. ${ }^{76}$ Police perpetuated a false image of what black activists and citizens were advocating for by painting them as anti-government radicals or communists. The greater community often aided in this surveillance work and would report seemingly innocent behavior as potentially malicious activist work. ${ }^{77}$ This

\footnotetext{
${ }^{73}$ Gervais, "The Portland Police Officer," 150.

${ }^{74}$ Serbulo and Gibson, "Black and Blue."

${ }^{75}$ Ibid.

${ }^{76}$ R.C. Cosby, "Intelligence Report: Possible Racial Problem in Williams Avenue Area" (Portland: Department of Public Safety Bureau of Police, July 25, 1968), Acc. A2004-005, Portland Archives and Record Center (henceforth referenced as PARC). This document gives direct evidence that the police stalked seemingly innocent people unprovoked. The police checked the residence of Melvin Spencer at 328 North Alberta and found a car with a California License Plate in the driveway. The officers sent a teletype message to California CIA and they reported that the car belonged to Gerald Ford. The police checked Ford's records to see if he was a "black militant," and his record was "clean."; C.F. Trimble, "Intelligence Report: Sidewalk Demonstration" (City of Portland, Oregon, Department of Public Safety: Bureau of Police, March 28, 1968), Acc. A2004-005, PARC. It details a non-threatening situation where the police interviewed him on the finances of his fashion company. Later, an informant in the police department told Brown that the police were targeting him for investigation.

${ }^{77}$ Gibson and Serbulo, Black and Blue; "“Operation Contact' The Church in the Streets," Action, October 1966, Acc. A2004-005, PARC; Trimble, "Intelligence Report: Sidewalk Demonstration"; Cosby, "Intelligence Report: Militants at Residential Manpower Center," Police Report (Portland: Department of Public Safety Bureau of Police, August 19, 1970), Acc. A2004-005, PARC. Workers at the Manpower Center, a residential center for men, were suspected of being black "militants." Accompanied with the
} 
harassment eventually aggravated some to a breaking point. In the summer of 1967 a group of young black Portlanders threw rocks and bottles at nearby police officers. This eventually turned into a riot, known as the Irving Park Riot, where fires were set, windows broken, and a local stereo store looted. Not one specific instance initiated the Irving Park Riot; instead, black citizens felt frustrated with unsolicited police presence in Albina. ${ }^{78}$ The Irving Park Riot took place during the "long hot summer" which witnessed urban rebellions in African American neighborhoods in Boston, Chicago, and Portland at the same time that a white middle class hippie movement enjoyed what they termed the "Summer of Love." ${ }^{79}$ Often these riots had no instigating factor, which left police and city officials puzzled. In Milwaukee's black community, heavy police surveillance of a school program caused the youth to riot. Milwaukee Police Chief John Polcyn claimed that a "hard core group of young hoodlums [was] to blame." ${ }^{, 80}$ Black citizens were often the blame of these riots, despite the police provocation.

After the Irving Park Riot, police presence and surveillance in Albina intensified. Federal efforts to disrupt the Civil Rights movement expanded in March 1968, when the head of the FBI J. Edgar Hoover established a Counter-Intelligence Program (COINTELPRO) in Oregon. ${ }^{81}$ COINTEL-PRO agents were in charge of infiltrating, reporting on, and disrupting Black Nationalist organizations to stifle black mobilization movements. Agents coordinated and encouraged sabotage efforts within local police bureaus.

report is a Xerox copy of all the men's photo ID's, provided by the Manpower Center.

${ }^{78}$ Serbulo and Gibson, "Black and Blue."

${ }^{79}$ Malcolm McLaughlin, The Long, Hot Summer of 1967: Urban Rebellion in America, (New York: Palgrave and Macmillan: 2014). For white middle class hippies, this time period was deemed the Summer of Love. The difference between the riots of the long hot summer and the protests of the summer of love exemplifies the difference between white privilege and urban minority frustrations.

${ }^{80}$ Balto, "Occupied Territory."

${ }^{81}$ Serbulo and Gibson, "Black and Blue." 
Sabotage efforts included FBI agents attempting to dissuade doctors from volunteering at the Portland Black Panther's free health clinic, accusing black nationalists of antiSemitism in an attempt to anger local Jewish leaders, and claiming certain black activists were actually police informants. ${ }^{82}$ By 1971, the FBI disbanded COINTEL-PRO after several states found documents from the program that violated the First Amendment. ${ }^{83}$ Although the PPB and the FBI were separate entities, both perpetuated similar harassment, surveillance and sabotage tactics against black citizens, and thus legitimzed each other's behaviors. ${ }^{84}$

The PPB also faced a lack of minority representation. Up until 1946, the PPB had hired only two African American police officers. The first worked from 1894 until 1915, and the second from 1946 to $1951 .{ }^{85}$ By the mid-1960s, very few Portland police officers were black—only one percent of the force's 720 officers. ${ }^{86}$ The Director of Personnel at the time, Andy Crabtree, asked if Captain Bill Taylor could be considered a Native American due to outside pressure to diversify the force. Taylor stated that he did have "Some American Indian blood (one-eighth)...but also Swedish, French and Irish

\footnotetext{
${ }^{82}$ Serbulo and Gibson, "Black and Blue"; Cosby, "Intelligence Report: Militants at Residential Manpower Center." Cosby suspected two men living at the Manpower Center could potentially be "militants," so he requested the security guard at the Manpower Center copy the men's drivers licenses and send them to the police.

${ }_{83}$ Ibid.

${ }^{84} \mathrm{Ibid}$; Trimble, "Intelligence Report: Sidewalk Demonstration”; Cosby, "Intelligence Report: Possible Racial Problem in Williams Avenue Area." Cosby's intelligence report provides insight on the type of surveillance officers were doing around this time. Cosby wrote in his report: "We...checked the residence of Melvin Spencer at $328 \mathrm{~N}$. Alberta. His car wa parked in front along with another car with a California License plate NDY961. A teletype message was sent to California CII and was returned as being registered to Gerald Ford." The PPB then checked Ford to see if he had a militant record and it was negative.

${ }^{85}$ Gayle Karol, "Dec 11, 1946: Almost the first black Portland police officer," Oregon Live, February 5, 2008; Alton Hornsby, "Black America," A State By State Historical Encyclopedia, n.d.

${ }^{86}$ Serbulo and Gibson, "Black and Blue."
} 
[blood]. ${ }^{\wedge 7}$ Regardless, Crabtree listed Taylor as Native Indian and eventually became falsely known as the first Native American police captain in Portland ${ }^{88}$ This lack of representation, combined with increasing police brutality, delegitimized law enforcement in the eyes of Portland's black residents.

In his 1968 report, Gervais identified a direct correlation between the experience and age of officers in the Bureau. Of the twenty-seven officers in the North Portland Precinct, only eleven were over the age of thirty. In 1968, the highest concentration of young officers worked in North Portland where the majority of Portland's black community lived. Additionally, older officers were more likely to participate in social organizations; younger officers often worked nights, which limited their ability to attend social meetings and furthered alienation within the community. ${ }^{89}$ An officer's age greatly affected his assigned shift and precinct. Younger officers often worked the night shift at the North Precinct as a result of seniority rules. The PPB assigned officers with more education to the Women's Protective Division, Communications and Sunshine Division. ${ }^{90}$ With this study we are able to paint a picture of the officers assigned to North Portland Precinct during the 1960s: overwhelmingly young, inexperienced, and less well educated.

Throughout the 1960s and early 1970s, citizens of Portland felt more and more

\footnotetext{
${ }^{87}$ William Taylor, "Sets Record Straight," The Oregonian, April 13, 1991.

${ }^{88}$ Ibid. In 1991 Bill Taylor wrote a letter to The Oregonian, who had recently referred to Taylor as an American Indian in an article about the diversification of Portland's police department. Taylor explained, In the 1960s "the bureau was under pressure to have more minorities. The director of personnel at the time, Andy Crabtree, asked if I qualified as an American Indian. I told him that I had never been listed as such but that I was about one-eighth Indian... I said that if the bureau would profit by calling me an Indian, that was okay with me."

${ }^{89}$ Gervais, "The Portland Police Officer," 15.

${ }^{90}$ Ibid.
} 
estranged from local law enforcement. The City Club of Portland released the "Report on Problems of Racial Justice in Portland," in which they concluded, "The policeman in the ghetto is a symbol... of a society from which many ghetto Negroes are increasingly alienated. ${ }^{91}$ Black citizens in Northeast Portland felt unrepresented based on the lack of community involvement and the minimal diversity on the police force. Likewise, officers often alienated themselves from Portland's African American community. When asked what community organizations they belonged to, 135 officers said they belonged to social organizations, 124 said they belonged to labor unions, and zero said they belonged to Civil Rights organizations. ${ }^{92}$ Over half of the officers assigned to the North Precinct claimed no affiliation to any sort of community organization.

Portland's black citizens were not the only victims of police totalitarian force and violence. In 1970, police targeted students of all racial backgrounds in a violent outburst that shocked and angered members of the overall community. On May 8, 1970, students and faculty at Portland State University went on strike to protest the recent police violence at Kent State University and the Vietnam War. ${ }^{93}$ On the fourth day, protesters and city officials agreed that the strike would end and the Portland Police Riot Control (TAC) arrived to take down the hospital tent that the protesters had erected. When the students refused to take down the tent, the TAC squad trapped and charged at the students with batons and tear gas. One officer remembered that the interaction was "not pretty,"

\footnotetext{
${ }^{91}$ Serbulo and Gibson, "Black and Blue"; also see City Club of Portland, Report on Problems of Racial Justice in Portland, June 14, 1968, 39.

${ }^{92}$ Gervais, "The Portland Police Officer," 21.

93 "Protesters Hurt in Park Blocks Clash," The Oregonian, May 12, 1970; John Guernsey, "Protest March Proceeds Calmly, Marred Only By Flag Incident," The Oregonian, May 8, 1970; John Guernsey, "Protest March Proceeds Calmly, Marred Only By Flag Incident," The Oregonian, May 8, 1970; John Guernsey, "War, Nerve Gas Protesters Arrested," The Oregonian, June 7, 1970.
} 
but remarked that "the streets were cleared" and the hospital tent taken down. ${ }^{94}$ Lester Lamm, a student activist who was present at the protest, described his friend's head getting "split like a pumpkin" as the TAC squad trapped the students and professors and bludgeoned them. ${ }^{95}$ Thirty-one people were treated at the hospital for injuries sustained by the police. Prior to the attack, the Portland press seemingly lacked compassion and did not engage in unbiased coverage towards the strikers. ${ }^{96}$ After the Park Block Riots, citizens heavily scrutinized the PPB for their attack on innocent and peaceful protesters, the majority of which were white students. The police agreed to never use force against nonviolent protestors again. ${ }^{97}$ However, the damage was done. Five years later during the Rickie Johnson investigation, many Portland State University alumni and anti-war advocates remembered their mistreatment by the Portland police and mobilized against the Bureau.

\section{Conclusion: Police violence against black citizens during the early 1970s}

The reputation of the PPB has fluctuated since the establishment of the burea.

With the onset of WWII, thousands of African American workers migrated to the greater Portland area, while simultaneously the PPB formed the nation's first successful police union, the PPA. After the war, Portland's black community settled and stabalized in the

\footnotetext{
${ }^{94}$ Ronald Still, Out of the Blue: From Rookie to Chief (La Quinta: Solana Publishing, LLC, 2007). Officer Still argues that the riots of activists in the 1960s and 1970s have been "replaced by gang warfare on the streets of our city. Tough enforcement remains the only remedy to defeat terrorism" (132). Still was unsympathetic towards the student activists, to say the least.

${ }^{95}$ Polina Olsen, Portland in the 1960s (Charleston: The History Press, 2012).

96 "Educators Announce Strike End," The Oregonian, May 11, 1970. Portland State University President Terry Wolfe and faculty member Jerry Walters indicated that the Portland press had not been as compassionate or as unbiased towards the strikers as it should have been.

${ }^{97}$ Joe Uris, "Portland State Strikers Sought Changed World," The Oregonian, May 6, 1990.
} 
city's Northern quadrant, Albina. With the help of the police, vice and organized crime flourished in the Albina neighborhood throughout the 1950s. Scandal and a public outting of police involvement in teamster racketeers caused the opinions of Portland police to plummet. In response to their own fall from grace and to nationwide civil rights and antiwar demonstraitons, the PPB adopted a "tough on crime" mentality throughout the 1960s and targeted black citizens as militants and criminals. With the ghettoization of Albina in the 1940s, the degredation of black neighborhoods with white vice in the 1950s, and the surveilance of black community members throughout the 1960s, the PPB continually suppressed the mobilization efforts of the city's black citizens.

Kenneth Gervais' study on the 1968 PPB demonstrated that there were two types of police officers working throughout the 1960s: activists and traditionalists. Activists sought innovations within the bureau, whereas traditionalists were more willing to maintain the status quo. ${ }^{98}$ Despite the officer's activist and traditionalist categorization, the majority of Portland Police in the 1960s did not support racial equality. Eighty-six percent of the Bureau felt that the Civil Rights Movement was moving "much too fast." 99 Officers who did support equal rights were more active in the community and also emphasized the importance of educated policemen. The nearly two hundred page study concluded: "The feeling that the public does not respect the police officer, or holds him in contempt, will most certainly affect the officer's attitude and behavior toward the citizen." ${ }^{100}$ Officers wished to emphasize the importance of complacent behavior from Portland's black citizens.

\footnotetext{
${ }^{98}$ Gervais, "The Portland Police Officer," 190.

${ }^{99}$ Ibid, 182.

${ }^{100}$ Ibid, 198.
} 
There are several important factors to consider while analyzing the Rickie Johnson killing. The three most important aspects include Portland Police history, black Oregon history, and the history between the white police force and black community. Portland has always had a disproportionate population; the city is over seventy percent white and less than ten percent black. Throughout its history, Portland's minority communities witnessed injustices in education, housing, and jobs. The PPB and the PPA have actively aided in the repression of the African American communities for generations.

In 1968, the City Club of Portland released a report on policing within the city. The commission argued that problematic policing by white officers in Albina indeed existed, and concluded, "the relationship of the police to the community is the most important problem of this and the next several decades."101 Nearly a decade after the published report, the city of Portland witnessed a streak of officer-involved shootings against men of color. In September 1974, Portland police shot and killed Joseph Hopkins, twenty-eight, while he ran down Southwest Fifth Avenue. Earlier, Hopkins shot at his neighbor's house during a psychotic episode and was allegedly carrying a gun. ${ }^{102}$

\footnotetext{
${ }^{101}$ City Club of Portland, "Report on Law Enforcement in the City of Portland" (Portland, OR, August 30, 1968). This quote was taken from a speech by Attorney General of the United States Ramsey Clark before a meeting of newspaper editors on April 17, 1968.

${ }^{102}$ Alan Hayakawa, "12 Shots Fired in Gun Battle That Killed Man," The Oregonian, November 22, 1974
} 


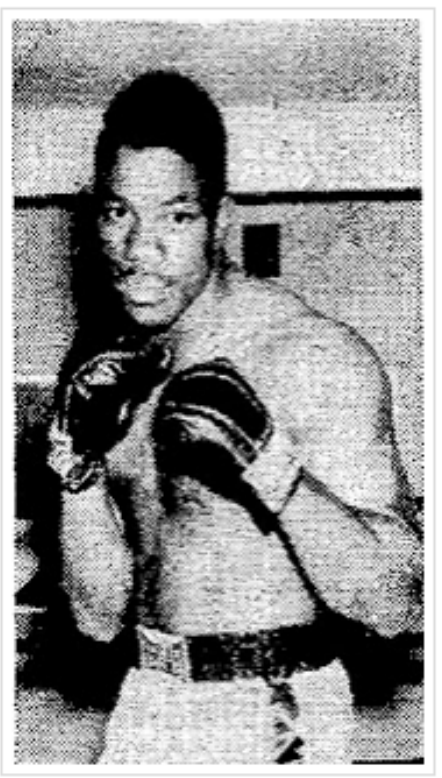

Figure 3: Joe Hopkins was a well-known and skilled amateur boxer in the Portland area. On the night of his death, Hopkins was experiencing a psychotic episode that was most likely caused by head trauma. He claimed his neighbors stole a box of kittens off his porch and so he fired a shot into their yard. Source: JD Chandler, "No Time to Learn," Slabtown Chronicle, August 24, 2016.

Less than a month later, in October, undercover police officers, participating in a sting operation to detain prostitutes and pimps, lured Kenneth Allen, twenty-seven, into their car. Allen allegedly promised the officers that they could sleep with prostitutes. He was shot several times in the back of the car once he tried to flee the situation. ${ }^{103}$ His death was ruled as justifiable homicide because Allen had a gun. ${ }^{104}$ However, his gun was never found. Portland State University's Black Student Union wondered, "Where is the gun? It has never been produced."105

\footnotetext{
${ }_{103}^{103}$ Alan Hayakawa, "Undercover Police Kill Suspect," The Oregonian, October 28, 1974.

${ }^{104}$ Black Students Protest Killing," Portland Observer, March 27, 1975, Portland Observer Microfilm: Reel 2, Oregon Historical Society.

${ }^{105}$ Ibid.
} 


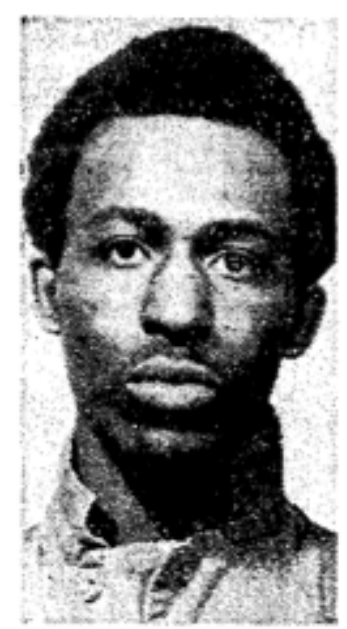

KENNETH ALLEN

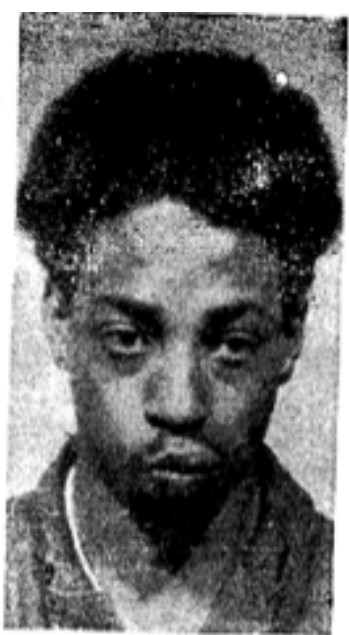

CHARLES MENEFEE

Figure 4: The pictures of Kenneth Allen and Charles Menefee, two victims of Portland police brutality, as shown in The Oregonian. The third victim, Joseph Hopkins, was not featured in the widely circulated newspaper. Source: Hayakawa, "12 Shots Fired in Gun Battle That Killed Man,"; Hayakawa, "Undercover Police Kill Suspect."

Portland police shot the third victim, Charles Menefee, during a twenty-mile car chase throughout Portland. ${ }^{106}$ The car chase was instigated after Canby, Oregon, police officers pulled Menefee over with out probable cause and he fled. Witnesses to Menefee's death reported that he had his hands up outside of the car before he was shot and killed by the police. ${ }^{107}$ None of the witnesses in the three cases were ever called to testify in court. All three of the men killed were black and lived in the Albina neighborhood of North and Northeast Portland. The deaths of Menefee, Allen and Hopkins outraged the black community, but received little attention outside the Albina community. Their deaths did not elicit significant protest or activism, and were hardly even mentioned in mainstream media outlets.

\footnotetext{
${ }^{106}$ Hayakawa, "12 Shots Fired in Gun Battle That Killed Man”; Hayakawa, "Black Groups Granted Inquiry into Police Shootings," 49.

107 "Black Students Protest Killing," Portland Observer.
} 
The fourth black male to be killed by Portland police within this five-month period was seventeen-year-old Rickie Charles Johnson. Unlike the Menefee, Hopkins, and Allen cases, Johnson's death was widely publicized within Portland's mainstream white population. His death received attention from activists citywide and continued the struggle against Portland police brutality. 


\section{$\underline{\text { Chapter } 2}$}

\section{Police brutality and black advocacy}

"Black brothers and sisters, let us continue our noble and heroic struggle for justice for all. Let us unite and organize the black community against all forms of oppression." ${ }^{1}-$ Activist Lucien Loiseau, "On the Murder of Rickey Johnson," 1975

\section{Introduction: The Death of Rickie Johnson, March 14, 1975}

Unbeknownst to many, a third teenager accompanied Homer Zachery and Rickie Johnson during their petty criminal escapades. After Johnson's death and Zachery's arrest, cab driver Martin Zamzow identified Homer Zachery as one of the perpetrators of the first robbery on March 12, but he could not identify Johnson as the second youth involved either because Johnson's face was unrecognizable from his wound, or because he was not the other offender that night. ${ }^{2}$ Moments after he saw Johnson shot on March 14, 1975, Zachery ran out the backdoor of the house and Officer Sanford fired two shots at him. The seventeen-year-old stopped and surrendered. ${ }^{3}$ Zachery did not have a weapon on him, and according to witnesses, the police handled him aggressively while they arrested him. Melva Thrower, an eye-witness to Zachary's arrest, testified that she heard three shots, one of which hit her car. ${ }^{4}$ She claimed that she saw Homer Zachery willingly stop and three police officers tackle him to the ground. According to Thrower, she heard Zachery ask about his friend Rickie, to which the officers replied, "That bitch is dead." After witnessing Johnson's death and Zachery's mistreatment, the third youth stayed

\footnotetext{
${ }^{1}$ Loiseau, "On the Murder of Rickey Johnson."

${ }^{2}$ Leverett Richards, "Hundreds of Spectators Jam Hearing into Shooting Shooting by Officer," The Oregonian, April 3, 1975; "Boycott Radio Cab Co.!!," Portland Observer, April 24, 1975.

3 Alan, "Black Groups Granted Inquiry into Police Shootings."

4“"Police Killing Justified, Black Juror Disagrees," Portland Observer, April 3, 1975, Portland Observer Microfilm: Reel 2, Oregon Historical Society.

5 "Police Killing Justified, Black Juror Disagrees."
} 
where he was hidden. ${ }^{6}$ Local activists agreed to protect the third youth and maintain his anonymity throughout the following advocacy efforts. ${ }^{7}$

The Portland community's response to Johnson's death varied. ${ }^{8}$ Some citizens believed Officer Sanford's actions were justified, since Johnson committed attempted burglary. These people claimed Johnson's death was just another example of rampant crime in the predominantly black neighborhoods of North Portland that the police needed to control. One citizen even sent Officer Sanford a twenty-dollar check for his "Vacation Fund," and offered to provide him with a babysitter. ${ }^{9}$ The donor, Esther Nichols, stated that "the community cannot say or accept that black is bad so it has to be the police that are wrong." ${ }^{10}$ Johnson's death revealed that a large portion of Portland's white residents held racist views and respected the decision of the police to use extreme violence against black citizens.

While Johnson's death solidified loyalty to the police in some communities, it also acted as a tipping point for other community members who believed that precedents set by racist officials needed to be changed. In response to Johnson's death, black community activist Lucien Loiseau argued that:

Certainly the world of racism... the world in which policemen dig the graves of our people and get away with murder..., the world of hatred, the world of felonies against [black people], the world of police assassination,

\footnotetext{
${ }^{6}$ Burke and Jeffries, The Portland Black Panther; Joyce Harris (BJC Member) in discussion with the author, February 28, 2015.

${ }^{7}$ Joyce Harris (BJC member) in discussion with the author.

${ }^{8}$ Lloyd Martin, to Neil Goldschmidt, March 27, 1975, Acc. A0237-01. PARC; Patricia Knight to Neil Goldschmidt, March 17, 1975, Acc. A0237-01. PARC.

${ }^{9}$ Esther Nichols to Kenneth Sanford, April 1975, Acc. A2014- 004. PARC. It appears that Nichols sent Sanford the check to indicate that an Officer such as Sanford should be supported and cared for and perhaps go on a vacation to relax.

${ }^{10}$ Ibid. Sanford returned the check to Nichols and said he could not accept the donation.
} 
must come to an end. ${ }^{11}$

Members of the community emphasized "Young Rickie's" unjust, cruel and untimely death and complained that Johnson was just another victim in a long-standing pattern of civil rights injustices toward black citizens by the PPB. ${ }^{12}$

Rickie Johnson often got into trouble with friends for minor crimes and petty theft. His father, Oscar Johnson, advised Rickie to be careful, and told him, "If the police ever catch you in anything, they're going to put a gun to your head and blow your brains out."13 Oscar worried that his son would fall victim to what many young black men encountered throughout the 1960s and 1970s: police brutality. As the fourth black male to be killed by Portland police within a five-month period, Johnson's death incentivized a young, radical generation of activists to speak out against police brutality and protest the PPB. These efforts by local activists contributed to the struggle against police brutality nationwide. The activism following Johnson's death caused the formation of new advocacy groups and furthered black mobilization efforts. These advocacy effortswhich varied between the efforts of young student activists, city sponsored advocacy, and the efforts of united black activists - forced the city to acknowledge the wrongdoing of police officers and host the city’s first public inquest.

\footnotetext{
${ }^{11}$ Loiseau, "On the Murder of Rickey Johnson."

12 "Black Student Union in the Black Community," 8; Knight to Goldschmidt, March 17, 1975.

${ }^{13}$ Hill, "Blacks to Seek Shooting Inquest"; "NAACP Requests Inquest into Shooting Death,"; Hayakawa, "Black Groups Granted Inquiry into Police Shootings."
} 


\section{Incident mishandlings and activist motivations}

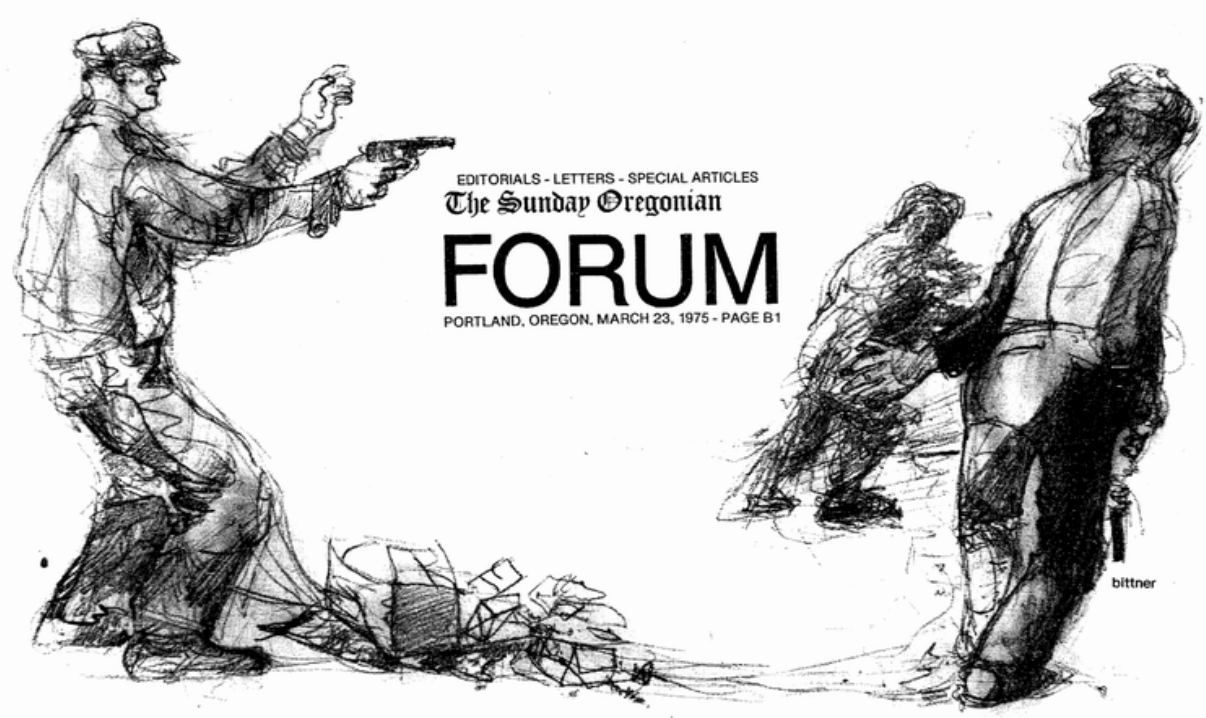

Figure 5: The Sunday Oregonian featured editorials, letters and special articles regarding Johnson's death and the surrounding advocacy efforts. Source: Sue Hobart, "Black Youth Slain. DA to Call Inquest over Shooting," The Oregonian, March 23, 1975.

News of Johnson's death by Officer Sanford rapidly spread throughout the black community which unveiled several instances of wrongful protocol. These instances provoked outrage and incentivized a younger generation of militant activists to protest police brutality in Portland. The issue that enraged black community members the most was that "Young Rickie" was shot in the back of the head. Although Sanford claimed Johnson crouched in preparation to shoot, the forensic evidence suggested Johnson instead attempted to flee. The official report by Portland detective Phillip Todd stated that investigators found the body in the dining room approximately ten feet away from his gun, which Johnson dropped in the living room. ${ }^{14}$ Additionally, Multnomah County

\footnotetext{
${ }^{14}$ Leverett Richards, "Hundreds of Spectators Jam Hearing into Shooting Shooting by Officer," The Oregonian, April 3, 1975; Sue Hobart, "Black Youth Slain. DA to Call Inquest over Shooting," The
} 
Coroner Dr. William Brady examined the hat Johnson wore at the time of the shooting. No powder or primer residue was on his hat, which meant that Sanford shot Johnson from more than six feet away. ${ }^{15}$ These findings supported the popular notion that Sanford shot Johnson while he ran away and demonstrated that Officer Sanford was never in danger. Lastly, Johnson's gun was unloaded and did not have a clip, while officer Sanford wore full body armor. ${ }^{16}$ Although Sanford had no way of knowing Johnson's gun was broken and unloaded, this detail sparked a larger conversation as to why Sanford thought it was necessary to shoot Johnson in the first place.

Overall, the black community believed that Sanford and the PPB handled the incident on March 14 inappropriately. Immediately following Johnson's death, the PPB released several conflicting stories. ${ }^{17}$ Police Chief Bruce Baker seemed confused when talking with Johnson's family about their son's death and gave them "unsupported suppositions on how the shooting took place. ${ }^{, 18}$ The PPB claimed they discussed different options to handle the situation before sending Sanford to the house. Black community members argued that sending multiple officers or back up would be high on the list of necessary precautions to take. However, Sanford went into the house alone. ${ }^{19}$ In his essay, “A Theory of Excessive Force,” sociologist Carl Klockars criticized officers who attempt to handle disturbances, complaints, and dangerous situations alone.

\footnotetext{
Oregonian, March 23, 1975; Spencer Heinz, "Officer Plays Cabbie, Kills Youth in Holdup Try," The Oregonian, March 14, 2015; "Picture Layout of Crime Scene," Portland Observer, April 3, 1975, Portland Observer Microfilm: Reel 2, Oregon Historical Society.

${ }^{15}$ Hayakawa, "Black Groups Granted Inquiry into Police Shootings," 49.

${ }^{16}$ Richards, "Hundreds of Spectators Jam Hearing into Shooting Shooting by Officer"; Hobart, "Black Youth Slain."

17 "Black Students Protest Killing," Portland Observer.

${ }^{18}$ Hill, "Blacks to Seek Shooting Inquest"; Hobart, "Black Youth Slain."

${ }^{19}$ Hayakawa, "Black Groups Granted Inquiry into Police Shootings," 49.
} 
Klocklars argued that skilled officers would not attempt to handle a situation alone. If a professional police officer decides to do so, then they should not be considered a highly skilled officer and should not be qualified to handle the situation. ${ }^{20}$ The Bureau claimed that they sent Sanford in to the house because he was highly skilled and suited to handle the job. However, the fact that Sanford went into the scenario completely alone shows the Bureau's wrongdoing. Conversely, most police officers interviewed felt that the Bureau handled the incident appropriately. However, one command officer interviewed by The Oregonian thought it was unreasonable to expect one police officer to control an armed robbery against two offenders. The officer explained that usually the officer would be electronically bugged and supported by several other officers to avoid this outcome. ${ }^{21}$ The officer interviewed requested that The Oregonian quote him anonymously, as he wanted to avoid criticism, intimidation and ostracism from fellow officers. ${ }^{22}$ Lastly, the Bureau claimed they contacted the Portland Special Task Force and the Task Force denied them help. When later confronted with this allegation, the Task Force said the Bureau never contacted them about intervening in the situation on March $14 .{ }^{23}$

The aforementioned instances of wrongful protocol sparked outrage within the black community and incited a larger conversation within the greater Portland community about the issue of police brutality. After years of organized crime and misconduct on behalf of the PPB, the Portland community demanded a thorough

\footnotetext{
${ }^{20}$ Klockars, "A Theory of Excessive Force and Its Control."

${ }^{21}$ Ibid.

${ }^{22}$ Hayakawa, "Black Groups Granted Inquiry into Police Shootings," 49; Hobart, "Black Youth Slain."

${ }^{23}$ Ibid.
} 
investigation of Portland police proceedings. ${ }^{24}$ Although white members of the Portland community voiced varied opinions on Johnson's death, the situation overall received greater attention from media outlets and citizens because of the circumstances surrounding the case. Johnson's age, his fatal wound, and the high rate of black victims recently shot by the Portland police elicited sympathy from many members of the white Portland community, and acted as a motivating factor for continued civil rights pursuits by black activists. Portland residents were anxious for the Police Bureau to be held accountable for its unjustified actions. They voiced their readiness through grassroots activism immediately following Johnson's death. ${ }^{25}$

\section{Activism}

\section{Advocacy efforts throughout the 1970 s}

By the 1970s, activism was not a new concept in America and was in fact a common strategy to push for social change. Between 1900 and 1960, African Americans locally and nationally achieved basic civil rights victories such as the repeal of voting bans, public accommodation bills that prohibited discrimination in public facilities, fairer employment laws, and open housing. ${ }^{26}$ In the 1950s and the 1960s, cities across the nation entered a period of "rapid civil rights reform" that came to be known as the Civil Rights Movement. ${ }^{27}$ Although many modern day Americans believe that the Civil Rights Movement began with the Supreme Court's 1954 Brown vs. Board of Education decision

\footnotetext{
${ }^{24}$ Robert Donnelly, Dark Rose (Seattle and London: University of Washington Press, 2011).

${ }^{25}$ Dr. Darrell Millner (Black Studies Emeritus professor at Portland State University) in discussion with the author, January 27, 2015.

${ }^{26}$ Burke and Jeffries, The Portland Black Panthers.

${ }^{27}$ Ibid.
} 
and ended with the Voting Rights Act of 1965, the movement extends far beyond this traditional narrative. In 2005, historian Jaquelyn Dowd Hall argued that the Civil Rights Movement should instead be more accurately called the "Long Civil Rights Movement" (LCRM). Hall deepened and broadened the "classical storyline... to include the struggles against economic, social and environmental injustice that continue even today." ${ }^{28}$ The idea of the Long Civil Rights Movement expands traditional scholarly notions of the movement by expanding the study of civil rights activism beyond the 1950s and 1960s and outside of American Southern states. The LCRM emphasizes the continued struggle for economic, judicial and societal equality. Johnson's story fits into the concept of a LCRM, as it happened outside the Southern United States and in the mid 1970s, thus temporally and spatially expanding the traditional narrative and supporting the notion of a continued and extended black mobilization movement.

In Portland specifically, the beginning of the 1970s saw an increase in grassroots activism and advocacy by citizens whom historian Carl Abbott labels "quality-of-life liberals. ${ }^{29}$ Although Abbott is primarily referring to middle class anti-urban renewal advocates, Portland witnessed various facets of constructive activism throughout the 1970s. Portlanders organized around neighborhood associations and pushed for women's rights, social and economic justice, and civil rights. Young black activists fought for racial, economic and social equality and against continued police brutality. Abbott contends "while hippies and their supporters...confronted city officials over lifestyle

\footnotetext{
28 "What Is the Long Civil Rights Movement," Triangle Research Libraries Network, http://www2.trln.org/ccc/context.htm; Purnell, "Freedom North Studies, the Long Civil Rights Movement, and Twentieth-Century Liberalism in American Cities"; Taylor, In Search of the Racial Frontier.

${ }^{29}$ Abbott, Portland in Three Centuries, 140.
} 
preferences and free speech, African Americans in Albina were challenging the Portland establishment about basic opportunities for life and livelihood." ${ }^{30}$

However, police brutality against communities of color - specifically black, Latino and Native American communities — continued to increase. By 1970, police conduct emerged as both a major social and political issue nationwide. ${ }^{31}$ Middle class citizens were concerned about the supposed increase in gun related crimes. Therefore, officers over-policed black neighborhoods and targeted African Americans as assumed criminals. Prior to the stop and frisk practice, which emerged nationally in the 1960s, historian Clarence Taylor asserts that there was a common "stop and question" practice, which further alienated African American residents from their local police. ${ }^{32}$ The overall air of activism of the 1970s encouraged black citizens to protest this increased surveillance and mistreatment by Portland police. ${ }^{33}$

In line with the rise in activism that occurred throughout the decade, the 1970s saw an eclectic mix of issues and instances that affected the Rickie Johnson case. The police brutality and harassment witnessed in the 1960s flowed into the 1970s and

\footnotetext{
${ }^{30}$ Ibid.

${ }^{31}$ Harlan Hahn, "Ghetto Assessments of Police Protection and Authority," Law \& Society Review 6, no. 2 (1971): 183-94.

${ }^{32}$ Clarence Taylor, "Introduction: African Americans, Police Brutality, and the U.S. Criminal Justice System," The Journal of African American History 98, no. 2 (n.d.): 200-204. In 1968, Terry v. Ohio made it much easier for law enforcement to "stop and detain someone when, based on their experience, they have a reasonable suspicion that criminal activity may be afoot." This justification eventually evolved into the popular "stop and frisk" practice we see today.

${ }^{33}$ The 1970s was a historically significant decade that saw the development of race as a social, political, and cultural category in the United States. During the 1950s, the City Club of Portland and League of Women Voters were the only two organizations that consistently advocated for the betterment of social public policies. Twenty years later by the late nineteen seventies, the roster of local lobbying and activist organizations differed immensely. There were now dozens of associations and groups who advocated for a wide range of causes, including social justice, environmental protection, affordable housing, consumer affairs and the arts. In fact, there were so many groups that the City of Portland published Portland Book: A Guide to Community Resources in 1979, which provided a comprehensive list of social change activist organizations. For more information, see Abbott, Portland in Three Centuries, 145.
} 
continued to rise. Black activists were all too familiar with these injustices. However, it was in the 1970s that the larger white community began to acknowledge wrongdoings against communities of color in Portland. Anti-war activists protesting the war in Vietnam encouraged whites to recognize the absurd and controlling nature of law enforcement nationwide. Race and advocacy were popular topics of discussion that bled into everyday life. This was especially true in Portland, where police officers were killing black men at an alarming rate. Years of police brutality in Portland, combined with increased militant advocacy in the 1970s shaped the response to the death of Rickie Johnson.

\section{Activism against Portland's police brutality}

Rickie Johnson's death elicited action by the Black Student Union (BSU) at Portland State University, which instigated the formation of a new civil rights group and solidified cooperation between black activist groups in Portland. This activism encouraged the city's non-black citizens to acknowledge the oppressive history of the PPB towards Portland's African American community. Shortly after Johnson's death, Kent Ford of the Portland Black Panthers challenged the students of the BSU at Portland State to take action and protest the PPB. ${ }^{34}$ Johnson's death was a personal matter for several BSU students; BSU member Rose Marie Allen was Kenny Allen’s sister, whom the police had killed a few months earlier, and fellow BSU member Sandra McFerrin was Rickie Johnson's sister-in-law. ${ }^{35}$ With Ford's encouragement, the BSU marched on the

\footnotetext{
${ }^{34}$ The BSU was founded in 1967 and was the impetus for the establishment of PSU's Black Studies department, which was founded in 1970.

${ }^{35}$ Charlotte Rutherford (BJC Member) in dicussion with author, February 12, 2015; "Charlotte B. Rutherford," (Business Card, n.d.), in Box 7, Verdell Burdine and Otto G. Rutherford Family Collection,
} 
police station to protest police brutality against Portland's people of color and to demand a public inquest to investigate Johnson's death. ${ }^{36}$ As the leader of the Portland Panthers, Ford witnessed years of intense and unfair brutalization of Portland's black citizens. In one such instance in 1970, Portland Police officer Stanley Harmon followed nineteenyear-old Albert Williams into the Portland Panther headquarters. There, Harmon shot Williams and critiquely wounded him. ${ }^{37}$ Ford and the Panthers, along with hundreds of other Portland citizens, vehemently criticized and fiercely protested the violent injustice. By 1975, however, the Portland Black Panthers had nearly been wiped out by Portland police harassment and surveillance. ${ }^{38}$ After Johnson's death, Ford figuratively passed the baton to Portland State students and encouraged young activists to push for the safety of black residents in Portland.

Charlotte Rutherford, a student at Portland State and member of the BSU, made an appointment with Police Chief Baker to discuss the BSU's demands regarding the investigation into Johnson's death. The BSU marched on the police station prior to the meeting to emphasize the outrage felt within the black community. Six people planned the march with Bill Harris, head of the PSU Black Studies Department, as their spokesperson. The march took place on March 18, 1975 in front of the police station on Southwest $2^{\text {nd }}$ Avenue and Oak Street in downtown Portland. Over two hundred Portland citizens participated in the protest, including Johnson's father, Oscar Johnson. ${ }^{39}$ Black

\footnotetext{
1900-1980, Portland State University Special Collection and University Archives.

36 "Black Student Union in the Black Community," 8.

${ }^{37}$ Burke and Jeffries, The Portland Black Panthers.

${ }^{38}$ This was true near in many areas across the county. Black Panthers were harassed and often jailed due to their activism.

39 "Black Student Union in the Black Community," 8.
} 
protestors carried signs that said "It's called Murder!" "17 years old!" and "Stop police murder! $" 40$

Once at the police station, Oscar Johnson, BSU members George Allen and Rutherford, and Professor Harris met with Police Chief Bruce Baker and submitted a list of demands representing the needs of the black community:

1) Officer Sanford must be expelled from the police department and brought to trial for murder.

2) The hearings regarding Rickie Johnson's murder must be open to the public to prevent a "whitewash."

3) Undercover agents must be withdrawn from the black community since recent events have proved they do not prevent crimes but instead commit crimes.

4) Massive recruitment must be had by the police department to recruit and hire black officers to serve the Black community.

5) The cases of Kenny Allen, Charles Menefee and Joe Hopkins should be reopened.

6) The state senate must appoint a committee to investigate these rash killings by Portland police. ${ }^{41}$

While advocating these demands inside, protesters outside surrounded the building and chanted, "Fire Chief Baker!" and "Baker is a child killer!" The march on Portland police station sent a clear message to city officials: the black community would no longer stay silent on the issue of police brutality.

\footnotetext{
40 "Front Cover," Ujima, vol. 1, no. 1, January 1975, https://exhibits.library.pdx.edu/items/show/355. Portland State University's Black Studies Department created Ujima, a black studies newspaper, in January 1975. The department "chose the name purposefully. 'Ujima' is Swahili for 'collective work and responsibility,' and that is what the newspaper will be." Ujima's goal was to "provide a vehicle of information for black students" and to be a "collective efforts by blacks for blacks."

41 "Front Cover," April 1975; "Black Student Union in the Black Community," 8. Although participants of the march were primarily African American, non-black members of both the Portland State and Portland communities participated.

${ }^{42}$ Jody Darby, Julie Perini, and Erin Yanke, Arresting Power, 2015.
} 


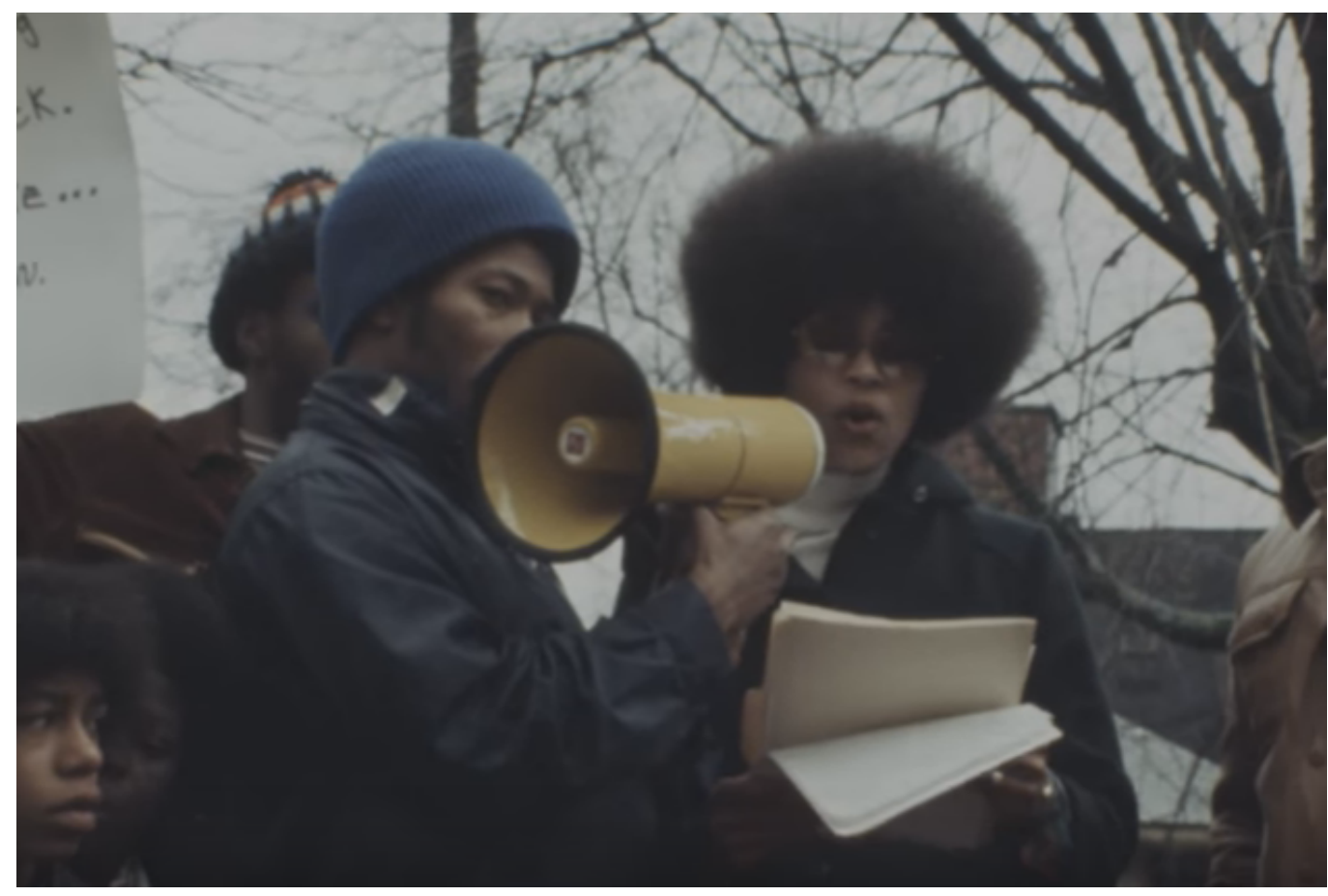

Figure 6: Charlotte Rutherford (right) speaking to the crowd at the march on the police station following Rickie Johnson's death. Source: KOIN News, “Civil Rights KOIN News Pull," 1975, Oregon Historical Society.

After the march on the police station, District Attorney Harl Haas and Chief Baker scheduled Multnomah County's first public inquest to be held on April 3, 1975. Activists believed continued momentum would further advocate their grievances and elicit change within the Bureau. Therefore, citizens of the black community began meeting regularly to discuss ways to combat police brutality in Albina. Black Portland resident Baruti Artharee suggested a smaller group should be assembled to strategize advocacy efforts surrounding the Johnson case. Hence, Artharee joined Rutherford in creating the Black Justice Committee (BJC). ${ }^{43}$ The BJC's constitution stated: "The purpose of the Black Justice Committee will be to respond to the expressed needs of the

\footnotetext{
${ }^{43}$ Maxine Bernstein, "Baruti Artharee Says His Personal Experiences Will Shape His New Job as Mayor Hales' Public Safety Policy Director," OregonLive The Oregonian, January 22, 2013, http://www.oregonlive.com/portland/index.ssf/2013/01/baruti_artharee_says_his_perso_1.html. 
Portland Black Community." ${ }^{, 4}$ The BJC's objectives included establishing a base for community development in the Albina community that could act as a liaison between black members of the community and political leaders, initiate black participation in community meetings, educate black citizens on their rights, and establish a broad base of support with other like-minded groups. ${ }^{45}$ Members of Portland State University's BSU joined the recently established BJC and its numbers grew quickly. ${ }^{46}$ Artharee became the co-chairman, and BSU member Rutherford also became the co-chairman. Shortly after the establishment of the BJC, Artharee said in a televised press conference:

This is more or less a situation in reverse where we have the criminal telling the victim that it's okay. It's okay if I hit you in the head, it's okay if I shoot you in the back of the head, it's the criminal telling the victim this. We are a community, if we're ever going to make a stand, it's time to take a stand and stop being victims... stop reacting and start acting. Speak up with voice and the power we have now before we won't even have that. ${ }^{47}$

The efforts of the BJC gave voice to young black activists and pushed the city of Portland to acknowledge police injustices and ameliorate wrongdoings against people of color.

\footnotetext{
44 "Constitution of the Black Justice Committee," March 1975, Verdell Burdine and Otto G Rutherford Family Collection, 1900-1980, in Box 7, Portland State University Special Collections and University Archives.

45 "Constitution of the Black Justice Committee."

46 "Black Student Union in the Black Community," 8.

${ }^{47}$ KOIN News, "Civil Rights KOIN News Pull," 1975, Oregon Historical Society, https://www.youtube.com/watch?v=jZkrR1dWdsg.
} 


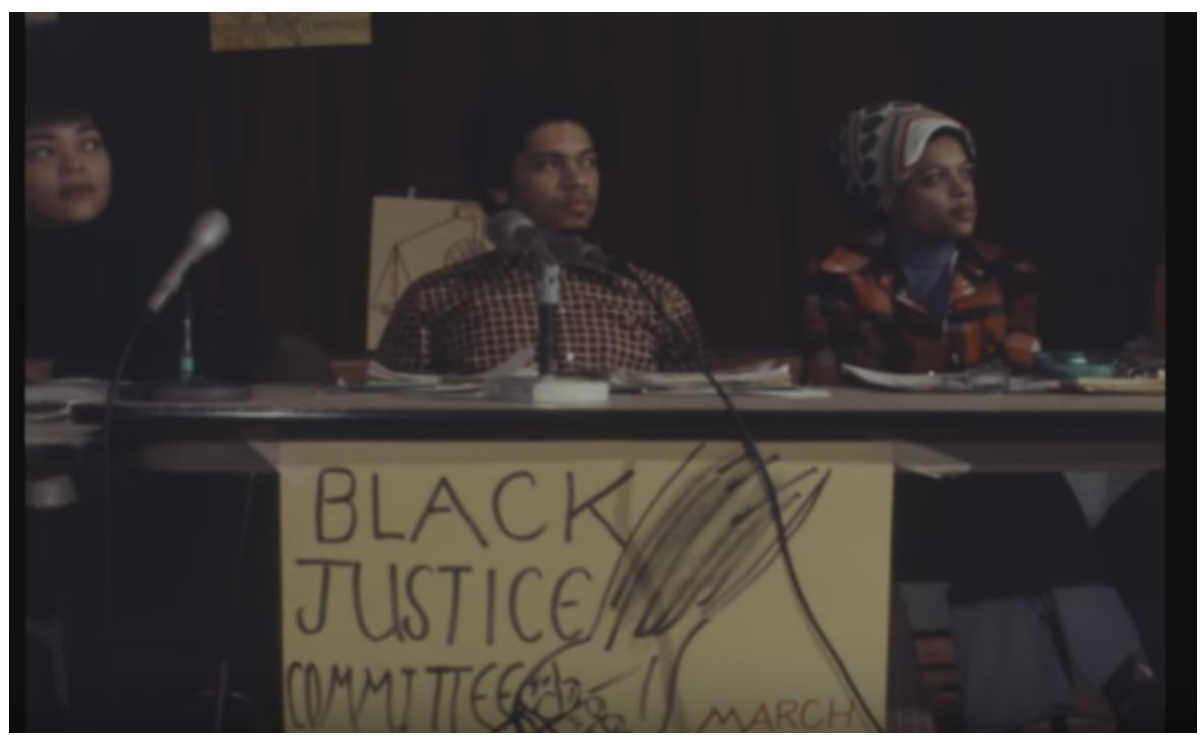

Figure 7: Charlotte Rutherford, left, and Baruti Artharee, center, at a press conference regarding the Black Justice Committee and Rickie Johnson's death. Source: KOIN News, "Civil Rights KOIN News Pull."

With the formation of the BJC, Portland's black community now had a determined and focused group advocating for the investigation of Johnson's death. Although other groups — such as the NAACP and the Urban League - protested police brutality, the BJC was the primary driving force behind the effort to bring justice for Johnson through a public inquest. The BJC held its first meeting on March 24, $1975{ }^{48}$ The group immediately organized a legal committee, a public relations committee, and a community inquiry committee to prepare for the inquest. The responsibilities of each committee were distinct. The legal committee's three responsibilities were to "seek legal advice; contact state attorney general's office; find out the date of inquest for the Rickie Johnson killing., ${ }^{, 49}$ The public relations committee dealt with community perceptions of the inquest. Its responsibilities were to "distribute petitions to get [Officer] Sanford out of

\footnotetext{
${ }^{48}$ Black Justice Committee Positions, March 24, 1975, Acc. A2004-005, PARC.

${ }^{49}$ Ibid.
} 
the black community; contact NAACP, Urban League, and other community organizations to invite them to work cooperatively with the Black Justice Committee; inform community using radio KQIV and newspapers. ${ }^{, 50}$ Lastly, the community inquiry team needed to "contact witnesses [of] the Rickie Johnson killing; investigate circumstances of Rickie Johnson's death; [brainstorm] questions to ask the District Attorney." ${ }^{51}$ The BJC specified in its constitution, "Anyone consistently disrupting the meeting will be warned once and then asked to leave." ${ }^{, 52}$ The BJC had a clear vision and functioned according to a weekly agenda, including opening remarks by Artharee, guidelines for meeting conduct, committee reports, questions from the audience, and a survey of business. ${ }^{53}$ This consistency and organization allowed BJC meetings to stay focused and committed to achieving its goals. The coordinated efforts of the BJC guaranteed that the investigation into Johnson's death continued.

The BJC began as a nine-person committee, but grew rapidly. By the time of the public inquest on April 3, the BJC included over seventy-five members, ten times the group's original size in less than a month. ${ }^{54}$ The group provided the community with a demanding yet peaceful advocacy committee that was respected within the greater Portland community. The formation of the BJC - a direct result of the Rickie Johnson murder - promoted civil rights activism against police brutality and inspired a new generation of young black activists to further dedicate themselves to specific action to combat police brutality.

\footnotetext{
${ }^{50} \mathrm{Ibid}$.

${ }^{51}$ Ibid.

${ }^{52}$ Ibid.

${ }^{53}$ Ibid.

${ }^{54}$ Richards, "Hundreds of Spectators Jam Hearing into Shooting Shooting by Officer," 48.
} 
Members of the BJC admired the militant activism portrayed by the Portland Black Panthers. However, the BJC recognized the negative connotation associated with the Panthers in Portland, especially regarding the police. The Portland Black Panthers faced years of conflict with the PPB, including unlawful surveillance, harassment, and negative press coverage. ${ }^{55}$ The BJC wished to emulate the Panther's militant tactics while retaining a positive reputation within the greater community. Therefore, the BJC committed to helping the city maintain order during the public inquest.

The BJC wanted the public inquest to remain open to the general public, and it feared that if the crowd got too disruptive the inquest would be shut down and the community would be shut out. District Attorney Harl Haas assured citizens that the inquest would be heavily guarded by deputies to prevent any disruptions. ${ }^{56}$ The BJC knew the police would use force if necessary and feared that the emotionality of the inquest might motivate communitiy members to act out. They wanted to protect the community and keep the environment of the inquest calm and controlled. Therefore, the BJC researched de-escalation tactics to be used during the inquest to ensure a safe and appropriate atmosphere for the general public. ${ }^{57}$ Eight BJC members wore red armbands during the inquest to signify that they could be called upon to help if a situation occurred. In one instance, a deputy barred Kent Ford from entering the public inquest due to limited seating. Ford then pushed the deputy, who responded similarly. The dispute ended when

\footnotetext{
${ }^{55}$ Jules Boykoff and Martha Gies, “'We're Going to Defend Ourselves'; The Portland Chapter of the Black Panther Party and the Local Media Response," Oregon Historical Quarterly 3, no. 3 (Fall 2010): 280-310.

56 "Haas to Arrange Inquest into Shooting," The Oregonian, March 26, 1975.

57 "Let Inquest Be Beginning," Oregon Journal, April 4, 1975; Richards, "Hundreds of Spectators Jam Hearing into Shooting Shooting by Officer," 48; "Black Student Union in the Black Community," 8. The Ujima article "Black Students in the Black Community," published in the spring of 1975, details Johnson's death on the night of March $14^{\text {th }}$ and continuously refers to him as "Young Rickie," to emphasize his youth and associated innocence.
} 
a member of the BJC gave up her seat in the courtroom for Ford. ${ }^{58}$ Another BJC member intervened when a scuffle broke out between Joe Uris, ex-student body president at Portland State University, and a local deputy. A member of the BJC again relinquished their seat so Uris could sit and the dispute would be resolved. With these cooperative procedures, the BJC hoped to provide an atmosphere that allowed the inquest to remain nonviolent and accessible to the public and, importantly, keep black attendees safe. ${ }^{59}$

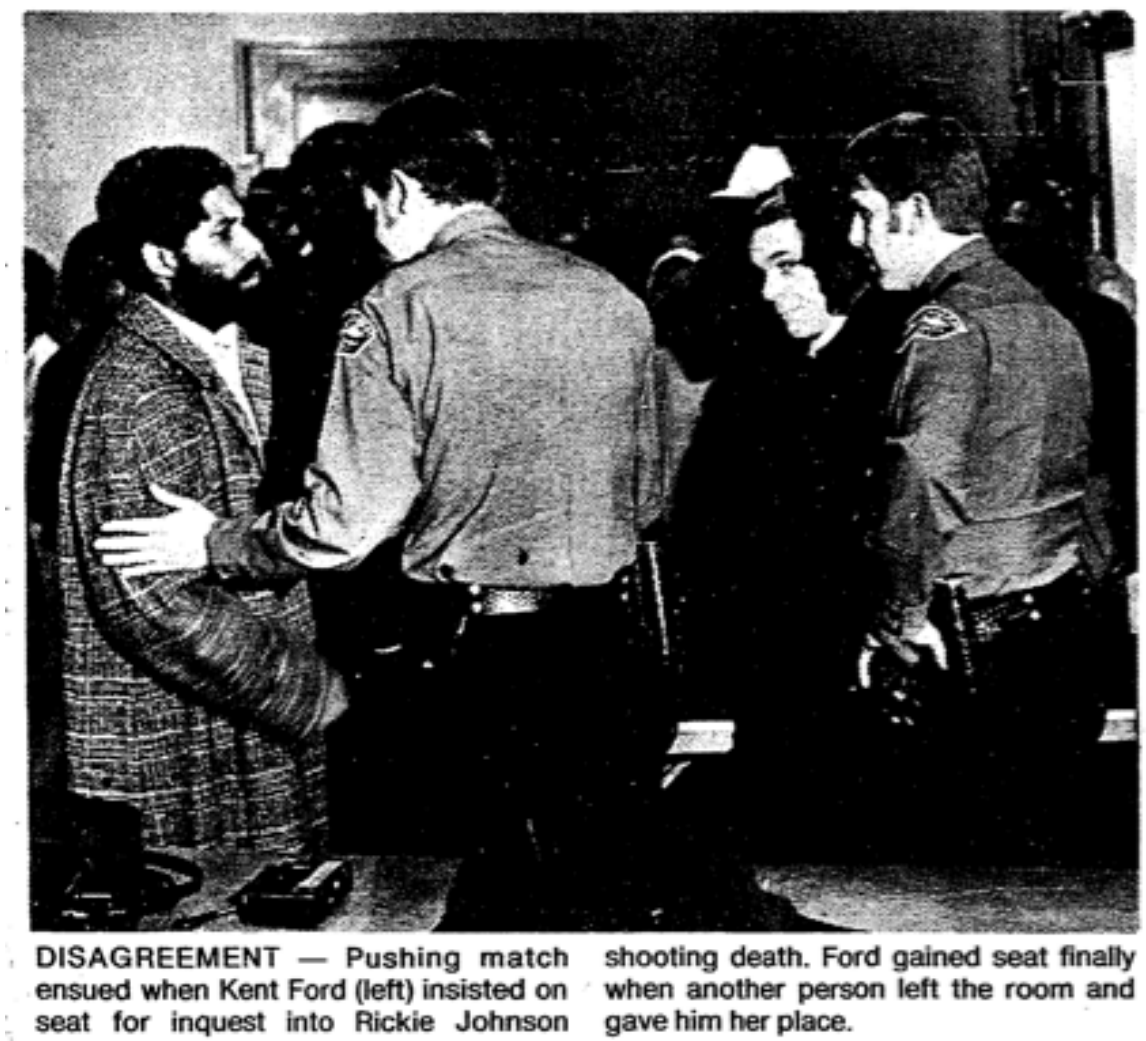

Figure 8: Kent Ford argues with a local deputy before a member of the Black Justice Committee steps in to stop the argument. Source: Richards, "Hundreds of Spectators Jam Hearing into Shooting by Officer."

The activism following Johnson's death started with a younger generation of black activists from Portland State University’s Black Student Union. These members

\footnotetext{
${ }^{58}$ Richards, "Hundreds of Spectators Jam Hearing into Shooting Shooting by Officer," 48.

59 "Black Student Union in the Black Community," 8.
} 
arranged a protest on the police station and quickly realized they needed to mobilize in order to continue their advocacy efforts. In response, black community members formed the BJC and focused their efforts on various avenues surrounding Johnson's case. The story of the formation of the BJC displays the ideas and actions of a large group of young black activists. The BJC inspired a younger generation of black activists and further united the black community. They were not, however, the only avenue of advocacy in Portland protesting police brutality.

\section{Black advocacy united}

Due to Portland's small black community, membership among black advocacy groups often overlapped. It was not uncommon for one person to be involved in several groups. Additionally, it was common for members of groups with opposing views to support one another. In the American South during the same years, it was unusual for members of the Black Panther Party to support members of the NAACP due to opposing tactics and views. In Portland, however, it was necessary for black citizens to support one another to ensure that their voices were heard. ${ }^{60}$ With the support of other black advocacy groups, black Portlanders felt their grievances would reach a larger audience.

Portland States University's BSU magazine Ujima shows the interconnectedness of black activism during this time. Members of the editing and writing team of Ujima were also members of the BSU, the BJC and the NAACP and the magazine reported positively on the varied efforts of the black community. ${ }^{61}$ Ujima detailed the march on

\footnotetext{
${ }^{60}$ Dr. Darrell Millner (Ermiritus Professor of Black Studies at Portland State University), in discussion with author, January 27, 2015.

61 "Black Student Union in the Black Community," 8; Rutherford in discussion with author.
} 
the police station and highlighted the subsequent list of demands presented by the students. Similarly, black-owned newspapers openly advocated for police reform and supported activists throughout the black community. The Portland Observer heavily covered Johnson's death and openly advocated for police reform. The Observer is Oregon's oldest continuously black owned newspaper. The publication covered Johnson's case from the time of his death in March 1975 until the federal investigation of Portland's police killings in October 1975. The Observer's first article on the issue appeared on March 20, 1975, with the headline "Police Bullet Kills Black Youth.” The article explained the circumstances surrounding Johnson's death, but also emphasized the "immediate reaction from the black community" in protesting Johnson's death. ${ }^{62}$ The word choice used throughout the Observer's coverage depicts militant advocacy for the investigation of Johnson's death but also the previous men killed by Portland police. Headlines such as "Black Students Protest Killings," "Police Killing Justified, Black Juror Disagrees," "Police Violence a Serious Crime," and "Black Justice Committee Demands FBI Investigate Police Killings" served as sources of direct newspaper advocacy. Likewise, these articles acted as a media outlet for protest groups such as the BJC to reach black audiences throughout Portland.

The Observer's pages further united the black community against police brutality. After the BJC announced its demand for a federal investigation, The Observer urged Portland's African American community to join the fight for justice, declaring: "The Black Justice Committee asked that the community join it in demanding an FBI

62 "Police Bullet Kills Black Youth," Portland Observer, March 20, 1975, Portland Observer Microfilm: Reel 2, Oregon Historical Society. 
investigation of the four shootings - all young black men and within a six month period. ${ }^{\prime 63}$ Throughout the preliminary investigation, the public inquest, and the federal investigation, the Observer acted as an ally to black activist groups in Portland. On March 27, 1975, the Observer published the list of demands the BSU presented to the city of Portland. This showed solidarity and support of the BSU in its advocacy endeavors. The Observer pushed agendas that protested police brutality in Albina and demanded punishment for those involved. ${ }^{64}$ This publication was meant to rally the black community to further push for police reform within Albina community. Largely read by only black Portlanders, these media outlets threw fuel on an already burning fire and encouraged black activists to continue in their fight for justice.

Other groups throughout Portland banded together to advocate for the public inquest and protest police brutality in Albina. These activist groups included Portland's chapter of the Nation Association for the Advancement of Colored People (NAACP), The Albina Ministerial Alliance (AMA), and the Urban League of Portland. Additionally, older generations of black activists supported the younger generations. This is evident in the communication and cooperation between the young participants of the $\mathrm{BJC}$ with the older members of the AMA and NAACP. Although many of these advocacy groups existed prior to Johnson's death, the incident encouraged members of black activist

\footnotetext{
63 "Black Justice Committee Demands FBI Investigate Police Killings," Portland Observer, April 17, 1975. ${ }^{64}$ Specifically, the Observer aided the BJC in their boycott on Radio Cab Company. The BJC felt that Radio Cab inappropriately aided in Johnson's death." The Observer also quoted BJC activist Gary Allen as saying: "Many complaints have been made in the past few years that Radio Cab drivers are disrespectful to black patrons." See "Black Justice Committee Demands FBI Investigate Police Killings," Portland Observer, April 17, 1975.
} 
groups to unite and form the Albina Coalition, also referred to as the Black Coalition. ${ }^{65}$ In order to more efficiently combat racial injustices, members of black advocacy groups in Portland formed the Black Coalition immediately after Johnson's death. The group included the head of activist groups throughout the black community. The Black Coalition unified activist groups and made it more apparent that these groups shared particular opinions about black rights in Portland. Letters to Mayor Neil Goldschmidt on the necessity of police reform are signed from "The Black Coalition" with member names attached. This made it clear to local politicians that members of the black community shared similar opinions on police brutality and other issues within the city. ${ }^{66}$ Black activists and community members wanted to send a message to local politicians that they not only supported each others varied endeavors, but all parties involved wished to combat the issues of police brutality within the city.

\footnotetext{
${ }^{65}$ The name of this organization is interchangeable between the Albina Coalition and the Black Coalition. The group will be referred to as the Black Coalition henceforth.

${ }^{66}$ Black Coalition to Edward H. Levi, Attorney General" April 24, 1975, in Box 19, National Association for the Advancement of Colored People (NAACP) Portland Branch records 1950-1970, University of Oregon Special Collections; Black Coalition to Mayor Goldschmidt, April 24, 1975, in Box 19, National Association for the Advancement of Colored People (NAACP) Portland Branch records 1950-1970, University of Oregon Special Collections.
} 


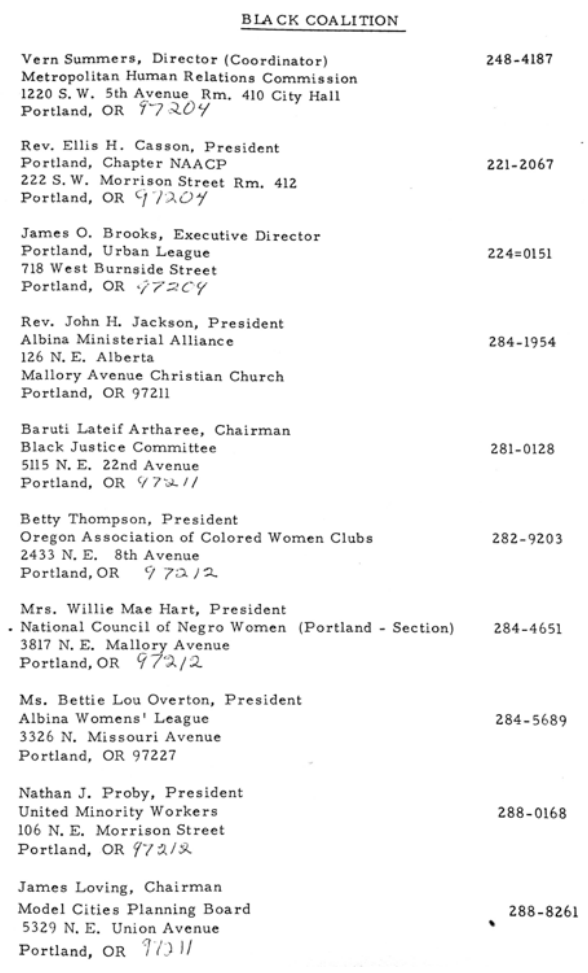

Figure 9: List of members of the Black Coalition from an early meeting of the group. Source: Black Coalition Members List, n.d., Box 19, National Association for the Advancement of Colored People (NAACP) Portland Branch records 1950-1970, University of Oregon Special Collections.

The connection's between black advocacy groups in the Black Coalition further strengthened community support of black activist demands. Members of the coalition included twelve heads of different activist groups including the BJC, the Urban League, the Albina Ministerial Alliance, the NAACP and the Oregon Association of Colored Women Club. ${ }^{67}$ Despite the similar interests of these groups, it was important to diversify the black community and separate its members into several different groups. This way, a

${ }^{67}$ Black Coalition Members List, n.d., in Box 19, National Association for the Advancement of Colored People (NAACP) Portland Branch records 1950-1970, University of Oregon Special Collections; Rich Measly, “Albina Ministerial Alliance,” http://www.blackpast.org/aaw/albina-ministerial-alliance-ca-1964. 
relatively small community turned into a larger and more demanding force ${ }^{68}$ The formation of the Black Coalition and the BJC were in direct response to the murder of Rickie Johnson. The formation of these new advocacy groups emboldened the black community and increased the recognition and attention the case received. The mobilization of activists after Johnson's death encouraged non-black communities to acknowledge the abuse against communities of color by the PPB.

In addition to advocacy efforts after Rickie Johnson's death, local black activists and groups wanted to protect Homer Zachery, the second youth involved in the attempted robbery. After the public inquest, the Black Coalition also discussed further advocacy efforts for the Johnson family. Oscar Johnson, Rickie's father, stated at an April 23, 1975, meeting of the Black Coalition: "The case for Rickie Johnson can wait while the BJC directs its efforts toward getting private legal counsel for Homer Zachery instead of the court appointed lawyer he now has." ${ }^{99}$ The Black Coalition, the BJC, the BSU and the NAACP all emphasized the importance of Zachery's legal representation. ${ }^{70}$ These groups believed a public defender would not offer Zachery the appropriate legal advice and would instead recommend that he plead guilty.

After switching between pleas of innocent and guilty multiple times, Zachery pled guilty to second-degree robbery on October 18, 1975. Zachery, who had earlier pled not guilty, changed his plea after the third day of his jury trial. By pleading guilty, Zachery admitted he was a willing participant in the robbery. In exchange for the guilty plea, the state agreed to dismiss a second charge of second-degree robbery from the March 12

\footnotetext{
${ }^{68} \mathrm{Ibid}$; Millner, discussion with author.

${ }^{69}$ Albina Coalition Meeting Notes, April 23, 1975, Acc. A2001-022, PARC.

${ }^{70}$ The BSU specifically supported the BJC in raising money to find Zachery new legal counsel.
} 
incident. At Zachery's sentencing, the judge said that by participating in the robbery, Zachery himself was responsible for Johnson's death, stating, "It should not come as a surprise when someone gets killed after pulling a gun on a policeman., ${ }^{, 71}$ Historian Michael Tonry argued in Punishing Race, "Policies and practices that create the severity of and disparity in criminalization endure because white empathy for blacks who are affected is weak and uncommon." 72 The judge sentenced eighteen year old Homer Zachery to seven years at the Oregon Correctional Institute. ${ }^{73}$

The death of Johnson by Sanford elicited several avenues of advocacy within the city. It especially motivated a younger generation of black activists. The BSU organized a march on the police station to demand further investigations into black deaths by white police officers; community members formed the BJC, a new activist group with the specific mission of motivating action for the investigation of Johnson's death; and the formation of the Black Coalition united activists of the black community throughout Portland to advocate against discriminatory city policies. All of these efforts helped continue the conversation of police brutality and reform within Portland, despite the PPB's efforts to intimidate black citizens and delegitimize their grievances.

\section{City sponsored advocacy and the PPB response}

Immediately following Johnson's death, community and city sponsored groups launched a litany of police reform program proposals. However, city officials shared

\footnotetext{
71 "Jury Selection Begins in Robbery, Death Cases," The Oregonian, October 15, 1975; James Hill, "Zachery Pleads Guilty, Draws 7 Year Sentence," The Oregonian, October 18, 1975.

${ }^{72}$ Michael Torny, Punishing Race: A Continuing American Dilemma (New York: Oxford University Press, 2011).

${ }^{73}$ Judge Ellis stated he would recommend Zachery spend his sentence at the Oregon Correctional Institute opposed to the maximum-security state penitentiary.
} 
varied opinions on the necessity of police reform—-specifically, police firearm reform. Many of the reform program proposals restricted police access to firearms and increased community policing within Albina. The Metropolitan Human Relations Commission (MHRC) spearheaded several of these police reform programs. Established in 1969 and comprised of political and civil rights leaders, the MHRC sought to promote "understanding, and respect between economic, religious, ethnic and social groups; arbitrate intergroup conflicts; and conduct programs aimed at improving intergroup understanding." ${ }^{74}$ Prior to Johnson's death, the MHRC focused their efforts on police reform. This included gun control and community-policing policies, which received divided responses from city officials_-including members of the PPB.

Shortly after Johnson's death, members of the MHRC asked Robert Lamb Jr., the Regional Director and Community Relations Representative for the U.S. Department of Justice, to advise the PPB on areas of police reform. ${ }^{75}$ Lamb recommended that the PPB adopt a more restrictive firearm use policy similar to that in Kansas City, Missouri. ${ }^{76}$ Lamb argued that this could help quell the overuse of firearms by PPB officers and thus diminish officer-involved shootings. The MHRC, which teamed up with the Police

\footnotetext{
74 "MHRC," City of Portland Archives and Records Center: Guide to historical records related to African Americans, PARC. The MHRC replaced the Portland Human Relations Commission, which had previously replaced the Portland Intergroup Relations Commission; the mission of each of these commissions was to improve race relations within Portland.

${ }^{75}$ Vern Summers to Robert Lamb, U.S. Department of Justice, May 20, 1975, Acc. A2001-022, PARC; Austin Harper to Robert Lamb, April 14, 1975, Acc. A2001-022, PARC; "Justice Observes Killing Inquiry," Portland Observer, March 27, 1975, Portland Observer Microfilm: Reel 2, Oregon Historical Society.

${ }^{76}$ Kalman Szeckely, "Letter about Shotgun Policy,” July 2, 1975, A2001-022, PARC; Marlene Bayless to Vern Summers, May 8, 1975, Acc. A2001-022, PARC; William Jackson to to MHRC Commission Members, May 14, 1975, Acc. A2001-022, PARC. Kansas City, Missouri's police firearm policy detailed when it was and was not appropriate for an officer to use a firearm. The policy also included rules for off duty police officers use of firearms and would specify the procedures to take after the use of firearms against citizens. The MHRC wished to emulate these procedures within the PPB.
} 
Community Relations Committee, recommended the new restrictive policies to Chief Baker. The recommended firearm reform policy used specific language about the types of weapons officers were authorized to use and the situations officers could use them in. It included a detailed police statement that outlined the PPB's philosophy behind the use of firearms. The MHRC and PCR believed a more specific policy would provide protection to both officers and citizens. ${ }^{77}$

However, the MHRC and PCR Committee met with resistance and policy retaliation from the PPB in response to the proposed firearm reform. A month prior to Johnson's death, the PPB initiated a policy that required officers to carry mounted shotguns in their police cars. Certain members of Portland's political communityincluding members of the MHRC — opposed this initiative and asked the Bureau to wait until further advised. After Johnson's death, the MHRC reiterated this request to wait on a decision about the shotgun policy until the city settled and until Lamb could further advise the bureau. However, only four days after Johnson's death, a MHRC member was watching the nightly news when a segment on the PPB's shotgun policy appeared. Officers demonstrated their new training technique for stopping and apprehending individuals with their shotguns. Previously, the MHRC had reached an agreement with Chief Baker that the use of shotguns by the PPB would not be decided until a study of other West Coast city's shotgun policies had been completed. ${ }^{78}$ However, the news segment claimed that the Portland police intended to implement the Shotgun Policy as

\footnotetext{
${ }^{77}$ William Jackson to MHRC Commission Members, May 14, 1975, Acc. A2001-022, PARC; Gregory Shinert to Kal Szeckely, July 15, 1975, Acc. A2001-022, PARC. Shinert highly recommends that the PPB do not install shotguns in their vehicles. He stated, "Nothing in my fifteen years of experience as a human rights worker has demonstrated either the need or wisdom of having shotguns in police cars."

78 "Memorandum Re: Shotguns/Police Bureau," March 20, 1975, Acc. A2003-001, PARC.
} 
soon as possible. Members of the MHRC felt disrespected and dismissed because the PPB went against advisory committees recommendations and implemented this controversial policy anyways. The PCR Committee of the MHRC agreed, "Most of the group felt that it was bad timing to the part of the police to be concerned about shotguns being placed in police vehicles" due to the proximity to Johnson's death. ${ }^{79}$ This sent a clear message to police reform activists that the PPB would act as it pleased despite community criticisms. Mary Warner, Assistant City Manager in Berkeley, CA, said of the shotgun policy and its untimely announcement, "My first reaction is 'you gotta be joking'... Clearly your police have learned nothing and Portland's black citizens are as vulterable as ever." $" 80$

Groups such as the PCR and MHRC wished to improve the relationship between officers and black citizens as well as increase the safety of both. However, the uncooperative nature of the PPB prevented immediate policy reform initiated by the MHRC. A year after Johnson's death, Vern Summers, President of the MHRC, resigned from the organization. Summers had been with the agency since its establishment in 1969. ${ }^{81}$ Summers stated, "The...MHRC has...gone as far as it can without any enforcement mechanism... In the past, any ordinance presented by the MHRC to the city council has been systematically removed [and dismissed]." ${ }^{\prime 82}$ This specific push back from the PPB and city government is one example of Portland's divided response on Johnson's death and the activism and legal proceedings that followed the case. However,

\footnotetext{
${ }^{79}$ Police Community Relations Committee Meeting Minutes; Minutes for Police Community Relations, July 11, 1975, Acc. A2001-022, PARC.

${ }^{80}$ Mary Warner to Kal Szeckely, June 17, 1975, Acc. A2001-022, PARC..

81 "Vern Summers Resigns from MHRC," The Skanner, May 20, 1976.

82 "Vern Summers Resigns from MHRC,"
} 
the efforts of the MHRC, like the efforts of the BJC, Black Coalition, AMA and NAACP, continued to work to stop police brutality in the city.

\section{Conclusion}

Nationally, the 1970s witnessed a unique combination of attempted social change and progressivism in addition to political scandals and the continuation of a long and ugly war. Historians Beth Bailey and David Farber maintain, "The 1970s were a different kind of drama. It was during the 1970s that the results of the major social movements of the previous two decades became concrete in American communities and in Americans' daily lives. ${ }^{183}$ During the 1970 s, citizens saw people of color on public television, the Nixon Watergate scandal, the end of the Vietnam War and a surge of gun related crimes. ${ }^{84}$ People began to think about not only race relations but also the meaning of race itself. Americans, as Farber and Bailey observed, “embraced, rejected, or otherwise negotiated racial identities and mobilized themselves around them in important ways." ${ }^{\text {} 85}$ One form of mobilization focused on the protest of police brutality against communities of color.

The longevity of these advocacy groups varied. Portland's Black Student Union continued to act as a voice for black students at PSU. It exists at the university to this day. The MHRC evolved and changed its name and mission multiple times throughout the years. The Black Justice Committee protested police brutality and unwarranted police

\footnotetext{
${ }^{83}$ Bailey and Farber, "Introduction."

${ }^{84}$ Mark Herzog, Tom Hanks, and Gary Goetzman, “Television Gets Real," CNN's The Seventies, June 2015.

${ }^{85}$ Eric Porter, "Affirming and Disaffirming Actions," in America in the 70s (Lawrence, Kansas: University Press of Kansas, 2004): 52.
} 
surveillance throughout Portland. The group eventually was absorbed into Portland's Black United Front and focused on battling school segregation. ${ }^{86}$ The Black Coalition was shortlived. Attendance dwindled after the public inquest. In June 1975, the president of the Black Coalition wrote to members and asked if they'd like to continue their membership. Archival epherma documenting the Black Coalition dates only from March 1975 until June $1975 .{ }^{87}$ Additionally, activists interviewed for this project did not remember the details of the advocacy group forty-two years later

Throughout their advocacy endeavors, these groups felt as if they met a brick wall of resistance. And despite some shortlived existences, these groups promoted Portland's black mobilization efforts and helped the momentum of the city's Civil Rights Movement progress. Johnson's death sparked further militant activism within the black community, as citizens demanded legal repercussions and policy changes within the city. This radical activism caused Multnomah County to host its first public inquest. While government agents such as the Police Chief and Mayor believed this inquest would deflate racial unrest in Portland, black citizens hoped the inquest would finally hold a member of the PPB accountable for the unnecessary death of a black young man.

\footnotetext{
${ }^{86}$ Harris, in discussion with author.

87 "Black on Black," Portland Observer, October 2, 1975.
} 


\section{Chapter Three: \\ Multnomah County's first public inquest}

"We, the inhabitants of the Albina area, honestly believe in the constitutional Bill of Rights of the US, but we do not approve of the discriminatory practices of those who control the judicial system in Portland." ${ }^{1}$-Lucien Loiseau, resident of Albina

After Johnson's death, District Attorney Haas and Police Chief Bruce Baker agreed it was in the best interest of Sanford and the community to hold Multnomah County's first public inquest. This, in itself, was an unconventional practice and provoked varied responses from citizens of Portland. A public inquest is a public "trial" that usually occurs after a sudden or unexpected death. Originally called a “coroner's inquest," the public inquest originated in England and was eventually utilized in the United States at the turn of the twentieth century. ${ }^{2}$ In Portland, the county coroner hosted the public inquest prior to 1973 . In 1973 Oregon legislature passed a law that gave inquest authority to the District Attorney.

The inquest's objective is to answer four questions: the name of the deceased, where and when the death occurred, what caused the death, and the manner of the death. ${ }^{3}$ Six jurors are chosen from a regular jury pool. The district attorney is permitted to ask relevant questions to the witnesses, and jurors can also submit questions for the district attorney to ask. After all evidence is presented, the jury is then dismissed to answer the four questions. If the jury decides the victim died of homicide, they are asked if it is

\footnotetext{
${ }^{1}$ Loiseau, "On the Murder of Rickey Johnson."

2 Portland Police Bureau, “A Report to the Community: James Jahar Perez,” November 2005, http://www.portlandoregon.gov/police/article/99881.

${ }^{3}$ Ibid.
} 
"negligence, justifiable homicide, murder or non-negligent manslaughter."4

Prior to the Johnson case, the county grand jury typically reviewed all shooting deaths that involved policemen. However, in 1973 the Oregon legislature stripped the grand jury of its authority to make written reports on jury's conclusions. Because of this new procedure, the public would not know the its decision making process or how it reached a conclusion. ${ }^{5}$ Due to the increased amount of citizen involvment and unanswered questions surrounding Johnson's case, the city decided to hold a public inquest. Thus, Sanford's public inquest acted as a fact-finding to expose the details of the event to the public. Baker encouraged transparency within the PPB; the facts surrounding the case were not obvious, and Haas and Baker hoped a public inquest would avoid further racial unrest. ${ }^{6}$ According to the Police Bureau, public inquests do the following:

Allow information to be shared, including educating the community on why [the police] do what they do. It benefits the bureau because a public airing of the facts can assist [the police] in terms of increasing credibility, rebuilding trust, and strengthening the relationship with the community.

It is apparent that Baker supported the inquest because he believed the Portland community would validate Sanford's actions and the PPB would be vindicated.

Technically, Sanford's inquest was the first public inquest in Multnomah County, but only because the Oregon legislature had changed the stated purpose of the inquest two years prior. Actually, Multnomah County had public inquests (previously called

\footnotetext{
${ }^{4}$ Portland Police Bureau, "A Report to the Community: James Jahar Perez."

5 "NAACP Requests Inquest into Shooting Death,"; "City Organizes Blacks," The Portland Observer, n.d., A2001-022, PARC.

6 “Answering for a Life," The Oregonian, March 27, 1975, sec. Editorial/Letters.

${ }^{7}$ Portland Police Bureau, "A Report to the Community: James Jahar Perez."
} 
coroner inquests) throughout the twentieth century. ${ }^{8}$ Thirty years before Johnson's death, a coroner's inquest was held to investigate the death of a black man by Portland Police Detective Bard Purcell. This inquest mirrored Sanford's inquest; a Portland police officer shot and killed a black man under controversial circumstances, whereupon the black community demanded further investigation. Purcell — the older brother of future controversial police chief "Diamond Jim" Purcell—and a team of detectives were sent to the Guild's Lake community in Portland to apprehend a black man suspected of murder. ${ }^{9}$ However, the police targeted the wrong man. Ervin Jones was asleep in his apartment with his wife, two children and two sisters-in-laws. Plainclothes detectives pounded on Jones' door and told him to come out. Assuming these men were civilians, Jones grabbed his gun. Purcell, perched outside the bedroom window, witnessed Jones grab his gun. Purcell shot Jones through the window. ${ }^{10}$ Following Jones' unwarranted and unlawful death, church organizations and the local NAACP demanded Multnomah County hold an inquest to determine whether or not Purcell's actions were lawful. The city complied, and an all white jury ruled Jones' death justifiable homicide. The city dropped the case. ${ }^{11}$

The decision to hold a public inquest and the results of it elicited strong responses from various community members in Portland. The local media perpetuated the idea that Sanford's inquest was the first public inquest in Multnomah County. Community

\footnotetext{
${ }^{8}$ The first coroner's inquest reported in The Oregonian occurred in 1907, when a young boy died of sudden spinal complications. Members of the community suspected that the boy died as a result of a beating and demanded a coroner's inquest. See "Why No Inquest?," The Oregonian, December 4, 1907.

${ }^{9}$ Chandler, Murder \& Mayhem in Portland.

10 "Officer Says Shot Fired to Save Partners on Raid," The Oregonian, October 11, 1945; "Police Obtain Statement Thomas in Jones House," The Oregonian, October 14, 1945.

11 "Inquest Jury Hears How Negro Died in Police Raid," The Oregonian, October 10, 1945; "Practical Religion," The Oregonian, October 1, 1945; "Probe Backed by Churches," The Oregonian, September 13, 1945; "Shooting Case Probe Asked," The Oregonian, October 13, 1945.
} 
members saw this inquest as a rarity and voiced their varied opinions openly. The advocacy surrounding Johnson's death showcased Portland's black actvists many efforts whereas, the results of Sanford's public inquest confirmed the powerful alliance between political and police machinery to shut down activist efforts. City government and the larger Portland community's non-unified responses to Johnson's death and Sanford's public inquest negated any immediate police reform and reified the untouchable power of the PPB.

\section{Citizen and city response to Sanford's public inquest}

Unsurprisingly, Sanford's public inquest instigated a varied response from Portland citizens and its political community. For many African Americans in Portland, the inquest was an official acknowledgement of officer wrongdoings. Many African Americans wondered, "Is death by gunfire reserved for blacks in Portland?",12 With Sanford's inquest, African American activists felt victorious in their demands that the city recognize Johnson's unjustified death. The inquest was an acknowledgement of officer wrongdoings against people of color. Support of the public inquest was not limited to the black community, however. Several white citizens voiced their interest in the inquest to support the black community's efforts. Additionally, some non-black citizens supported the public inquest simply because the facts surrounding the case “caused unusual public concern." 13

Other Portland citizens did not support the public inquest and felt members of the black community were exaggerating the issue of police brutality. Hugh Havercamp of

\footnotetext{
${ }^{12}$ Hayakawa, "Black Groups Granted Inquiry into Police Shootings."

13 "Answering for a Life."
} 
Northwest Portland wrote to Mayor Neil Goldschmidt stating, "WELL DONE MR. POLICEMAN AND DID YOU CATCH THE OTHERS TOO?"14 Opponents of the public inquest did not understand why the community was making Johnson's death into a "race issue." ${ }^{15}$ In a letter to Chief Baker, Watford Read of Portland argued that hosting a public inquest would prove that "black people are privileged" in Portland, as public inquests were not held for most police related shootings. ${ }^{16}$ Several citizens loyal to the Portland police argued, "If the criminal refuses to surrender his weapon, then they should rightfully suffer the consequences. ${ }^{117}$ Certain members of the community believed the public inquest was an effort by the black community to intimidate the Police Bureau. ${ }^{18}$ For Portland's politicians, the inquest was a way to appease an outraged population while still maintaining racial norms and police suppression practices within the city. Mayor Neil Goldschmidt's response to the public inquest epitomized the city's complicated opinions. Largely recognized as the mayor responsible for liberalizing Portland, Goldschmidt was a young progressive who found support in many communities. However, immediately following the shooting, Goldschmidt was silent. He did not instigate the inquest, and could not be reached for an opinion or a quote. By March 24, 1975, exactly ten days after Johnson's death, District Attorney Haas wrote to

\footnotetext{
${ }^{14}$ Hugh Havercamp to Neil Goldschmidt, April 2, 1975, Acc. A2004-005, PARC.

${ }^{15}$ James George to Neil Goldschmidt, March 24, 1975, Acc. A2004-005, PARC. George, like many Portland residents, believed the black community needed to intervene and teach the younger generation that "crime is a dangeorus profession... and should consider other fields of endeavors." George berrates Goldschmidt and Baker and argues that Portland did not need a public inquest, but instead needed "city government with a backbone."

${ }^{16}$ Watford Reed to Chief Baker," April 8, 1975, Acc. A2003-001, PARC. Throughout this letter, Reed refers to Rickie Johnson as the "would-be robber." He praises Sanford for his "handling of the situation which ended him killing a would-be robber."

${ }^{17}$ G Hendericks et al., to Neil Goldschmidt," March 28, 1975, Acc. A2003-001, PARC.

${ }^{18}$ Neil Goldschmidt to Lloyd Minter, April 1, 1975, Acc. A2003-001, PARC; “Trucker Harassed," The Oregonian, April 5, 1975.
} 
Goldschmidt to inform him of the decision to conduct a public inquest. Although Haas and Chief Baker discussed the necessity of a public inquest, Haas had not yet heard from the mayor. Haas wrote: "I presume, since we have had no contact from your office, that this conveys the understanding between you and the PPB." ${ }^{19}$ Goldschmidt avoided this controversial situation in hopes of evading the spotlight himself.

Eventually, Goldschmidt spoke about the inquest. Nearly a week after Haas wrote to him, Goldschmidt replied: "I view the special inquest as a public hearing at which Officer Sanford will be vindicated for his actions. It will provide an open forum for members of the minority community to learn first hand what occurred and why Officer Sanford felt it necessary to shoot." ${ }^{20}$ Goldschmidt wanted to make his support of the police evident to stay in their good graces, yet he also wanted to appear to be on the side of black activists. While Goldschmidt was confident in Sanford's vindication, he also met with leaders of the black community to guarantee some type of police reform would result from Johnson's death. ${ }^{21}$ Goldschmidt assured members of the Albina Ministerial Alliance that the PPB was "the community's police bureau," and that a "thorough examination of police policies would be appropriate following the... inquest." ${ }^{, 2}$ Goldschmidt also met with members of Portland State University's Black Student Union to discuss proposed reforms of police presence in Portland's black community. ${ }^{23}$ Mayor Goldschmidt tried to play the neutral middleman throughout the public

\footnotetext{
${ }^{19}$ Harl Haas to the Honorable Neil Goldschmidt," March 25, 1975, Acc. A2001-022, PARC.

${ }^{20}$ Neil Goldschmidt to Letter to James George, March 31, 2016, Acc. A2000-017, PARC.

${ }^{21}$ Huntly Collins, “Albina Ministers, Mayor Discuss Police Changes," The Oregonian, March 28, 1975.

${ }^{22}$ Ibid.

23 "Letter to Mayor Goldschmidt from Activists in the Black Community," April 24, 1795, Box 19, National Association for the Advancement of Colored People (NAACP) Portland Branch records 19501970, University of Oregon Special Collections; "Inquest Inadequate," Oregonian, April 4, 1975.
} 
inquest. He received several letters from citizens who voiced support or disdain for the PPB. In response to each of these letters, Goldschmidt carefully constructed his response to avoid alienating himself from either side of the argument. Goldschmidt made it evident that he was deeply saddened by Johnson's tragic death and believed police reform neccessary, but he emphasized equally the well-being and safety of Portland police officers. Goldschmidt attempted to appease as many community members as possible in hopes of diffusing an already tense situation.

Furthermore, the police union criticized District Attorney Haas for his decision to hold a public inquest. The PPA believed the inquest unnecessary and accused Haas and Baker for further complicating the case by not following standard bureau protocol. Shortly after the announcement of the public inquest, Stan Peters, president of the PPA, released a statement questioning the legitimacy and justification of the inquest. Peters did not explicitly support Sanford's actions, but instead opposed any alteration of the Bureau's standard investigative procedure. Peters argued that because the PPB had already subjected officers to "lengthy and detailed inquiries by supervisors, detectives, district attorney's office, the firearms board, and the grand jury," they should not have to be subjected to the public. ${ }^{24}$ Peters acknowledged and accepted the necessity of these procedures in order to "insure officers act in a professional, responsible manner." 25 However, by deviating from this procedure and holding a public inquest, the police union argued that the district attorney was refusing to accept his professional responsibilities. Peters declared: "If [Haas] felt the police officer had committed a criminal act, he should

\footnotetext{
${ }^{24}$ Stan Peters, "Statement by Stan Peters to President Re Special Inquest," March 31, 1975, Acc. A2001022, PARC.

${ }^{25}$ Ibid.
} 
have immediately presented the case to the Grand Jury instead of hiding behind the cloak of a public inquest. ${ }^{, 26}$ Peters and the PPA believed that the public inquest rendered officers vulnerable and unprotected among a community where a large percentage vehemenently disagreed with their actions. Peter's argued that this inquest would further complicate the process, as the inquest would go against all previously established procedure. $^{27}$

Although Chief Baker supported Haas' decision to conduct a public inquest, his allegiance remained with the safety of his police officers. Baker reassured his officersin particular, Officer Sanford — that the PPB was almost always questioned after incidents involving an officer's use of a firearm on a citizen. The PPB's firearm policy, Baker believed, did not differentiate between or target groups of citizens based on ethnicity or race. In a public letter, Baker wrote: "A human life is a precious thing, an indisputable fact that motivates [many] to become peace officers, thereby demonstrating [the] desire to make [The Portland community] a safe place. ${ }^{.28}$ Baker emphasized that despite the tragic death of Rickie Johnson, police officers had the right to defend themselves. He wrote:

There should be no hesitation in defending another or your own life... For protection from physical harm, you have the authority of the law and the system of justice we are sworn to uphold. In the ultimate case, where life is endangered, you should follow our policy and defend yourself. ${ }^{29}$

\footnotetext{
${ }^{26}$ Peters, "Statement by Stan Peters to President Re Special Inquest."

${ }^{27}$ Members of the PPA raised money to cover Sanford's attorney cost. The PPA argued that the police bureau should cover these costs, but Baker retaliated that the PPB had no obligation to represent Sanford at the inquest. Baker also emphasized that the inquest, realistically, had no authority to bring a criminal indictment. See Alan Hayakawa, "Fellow Officers Help Pay Legal Bill," The Oregonian, May 16, 1975.

${ }^{28}$ Bruce Baker, "Letter to All Concerned," April 23, 1975, Acc. A2001-022, PARC.

${ }^{29}$ Ibid.
} 
Baker believed a public inquest was necessary to quell racial unrest from activists and to provide the appearance of transparency to avoid further persecution of Portland police officers. Ultimately though, Baker supported Officer Sanford's actions and cared about his and other officers well being.

\section{Kenneth Sanford's public inquest, April 2, 1975}

Regardless of the polorizing opinions by citizens and city officials, District Attorney Haas and Assistant District Attorney John Moore held the public inquest on April 2, 1975. Over four hundred spectators attempted to attend the public inquest trial. The courtroom could house only ninety-six people (including press), and only twenty-two Multnomah deputies were available to control the crowd. ${ }^{30}$ Two hundred people were jammed into the county commission chamber to watch the trial on closed circuit television, and more than one hundred people were left to wander the halls. ${ }^{31}$ Members of the BJC wore red arm bands to help Multnomah County Deputies manage the crowd at the inquest. The BJC were the main motivators of the public inquest and hoped to get answers to their previously submitted questions.

First, witnesses testified. The shooting the night of March 14 occurred at 1:45 a.m., and at 2:20 a.m. Zachery signed away his right to remain silent and his right to have an attorney present. At 3:00 a.m. detectives recorded his testimony of the incident. Zachery declined to appear at the inquest, but Moore played the tape recording of his

\footnotetext{
${ }^{30}$ Richards, "Hundreds of Spectators Jam Hearing into Shooting Death by Officer."

${ }^{31}$ Ibid. Several high profile Portlanders were there to show their support of the inquest. Portland Trail Blazer Bill Walton attended the trial, as well as the majority of the protests, to show his support of the black community.
} 
testimony. Zachery claimed he thought Johnson was just ordering Chinese food and did not know of his intention to rob cab driver Martin Zamzow. Zachery admitted he knew Johnson had a gun, but did not think he would use it because it was missing a clip. ${ }^{32}$ Next, cab driver Martin Zamzow testified, reiterating what happened during the first robbery on March 12; he delivered food to the house when two youth robbed him with a baseball bat and a gun. He later identified Zachery as the youth with the baseball bat, but could not positively identify Johnson. ${ }^{33}$

After Zachery and Zamzow's testimonies, Moore questioned the officers involved that evening. Sergeant Melvin Nilsen had been in charge of the men on the scene. Nilsen testified that he, detectives Phillip Todd and Rob Benson, and officers Demitrakikes, Baxter, Linhares and Marshall surrounded the outside of the house as Sanford, dressed as a cab driver, entered the house. When questioned why Sanford entered alone, Nilsen said he had been in the house two nights prior on March 12 to investigate the first robbery, and because he was "stable and mature." ${ }^{34}$ Nilsen stated that he and Sanford had no conversation about shooting, but clarified, "If the man had pulled a gun on me, I would have fired directly through the cardboard box [of Chinese food]" without hesitation. ${ }^{35}$ Next, Detective Todd testified. He claimed he heard a discussion on how to

\footnotetext{
${ }^{32}$ Richards, "Hundreds of Spectators Jam Hearing into Shooting Death by Officer."

${ }^{33}$ Zamzow did not recognize Johnson either because Johnson was not the other perpetrator that night, or because his face was too disfigured from his wound.

34 "Police Killing Justified." Throughout this research, I struggled to find a transcript of the inquest. The Portland Observer is the only publication to detail the inquest with a list interviewees and quotes from their testimonies. Additioanlly, The Observer is Portland's longest running black newspaper. Portland boasts a rich history of advocacy in print via its African American newspapers. Portland's first black newspaper, The Advocate, ran between 1903 to 1933. Editor and journalist Beatrice Cannady often published articles describing instances of discrimination. In The Advocate, Cannady often advised black Portlanders to boycott establishments who participated in these racist practices. McLagan, A Peculiar Paradise.

35 "Police Killing Justified"; "Boycott Radio Cab Co.!!,"
} 
proceed if the man in the house drew a gun on Sanford, and they instructed Sanford to fire through the box. After Sanford entered the house, Todd heard two shots fired and saw Zachery run out the backdoor. Sanford fired two shots at Zachery, and the boy surrendered. Todd, however, was adamant that he saw another black male run out of the house through a different exit. The third male disappeared between the houses and the officer did not pursue him. ${ }^{36}$ Todd entered the house whereupon Sanford handed him his gun. Todd began his investigation of the scene. He testified that he found Johnson's body face down with his feet "thirty-nine inches north of the south wall of the dining area. His weapon was two feet, seven inches north of the south wall of the house, so about ten feet from [Johnson's] feet. ${ }^{37}$ Todd admitted that he found no clip or ammunition for Johnson's gun. Moore asked Todd why he thought Sanford fired at Johnson, and Todd responded that a police officer will "automatically shoot at the largest part of the body, the trunk, to disable, although this can result in death. ${ }^{38}$

Officer Demitrakikes testified that he was with Officer Baxter a half block away from the house when they heard the shots. Demitrakikes ran to the front of the house, and Baxter to the back. Baxter testified he entered the house and saw Sanford kneeling over Johnson, whereupon Sanford put his own gun on the kitchen counter. Officer Marshall testified that he was with Sanford on the drive over to the house. Sanford drove as Marshall hid in the back of the Radio Cab. Marshall remembered and testified that

\footnotetext{
36 "Police Killing Justified." The black male that Todd claimed he saw, although never identified, was most likely the third youth involved that the BJC vowed to protect throughout the process.

37 "Police Killing Justified."

${ }^{38}$ Ibid.
} 
Sanford said, "If anything happens to me, tell my wife and daughter I love them." ${ }^{39}$ This emphasized Sanford's fear and vulnerability to the jury. After he heard the shots, Marshall entered the house to check on Sanford. He expressed concern about Sanford's safety and well-being. He explained that both he and Sanford were upset with many thoughts running through their minds. He excused this behavior and clarified, "any time a shooting occurs you will be excited" and not clear-headed. ${ }^{40}$

The Portland Observer reported that Moore asked all officers leading questions that allowed them to give justifiable reasons for Sanford's actions. For example, Moore asked, "Did Sanford shoot because he was afraid?" whereupon the officers responded, "Yes, Sanford fired his gun because he was afraid." ${ }^{41}$ It is obvious in this coverage that the police officers interviewed were able to communicate their side of the story. A reporter for the Observer said, "Leading questions were asked to the police witnesses, giving them justifiable reasons for their actions and then asking if that was their reasoning. ${ }^{, 42}$ The questions helped paint the officers as brave heroes who risked their lives. Additionally, the answers provided by the officers clearly supported Sanford and his choice of action to shoot Johnson. They emphasized how sensitive, stable, and nice Sanford was and thus elicited emotional responses from the jury.

Other witnesses who testified included Melva Thrower, a neighbor on North Gantenbein. She testified that the officers used profanity and handled Zachery roughly upon his arrest. She stated they threw Zachery on top of the police car before tossing him

\footnotetext{
${ }^{39}$ Ibid.

40 "Police Killing Justified."

${ }^{41}$ Ibid.

${ }^{42}$ Ibid.
} 
into the back seat. When Zachery asked about Johnson, they said "That bitch is dead," and asked "Where does that MF live?"43 Instead of focusing on the treatment of Zachery, Moore questioned the offcers about Thrower's testimony and asked if they used profanity. The officers admitted that "profanity was used," but they couldn't remember what profanities. Another officer claimed he heard "loud language" but could not determine if they were profanities. ${ }^{44}$ This heavy emphasis on such an insignificant detail seemed irrelevant in the grand scheme of contentious circumstances involved in the case. Moore's immaterial questions avoided hard-hitting discussions. This created a false sense of transparency and presented unimportant information to inquest attendees.

Laslty, Officer Sanford took the stand. Sanford attested that he volunteered to participate in the sting operation, and stated, "I felt that if someone was in the house it was very likely that a dangerous situation would arise. I felt perhaps a robbery would occur. ${ }^{45}$ Despite his apprehension, Sanford claimed he had not planned to shoot, but instead decided to "play it by ear." ${ }^{, 6}$ Sanford further explained:

As I drove up, someone opened the door and looked out. He stepped back inside... I carried the box [of to go food] with my left hand, with the gun inside the box in my right hand, and walked onto the porch. Zachery held open the screen door; the front door was open. [I] entered the house and stepped to the left of the front door. Zachery was standing in front [of me] to my right, Johnson was against the living room wall in front of me... Johnson had his left hand on his cheek and his right hand in his coat. He lowered his left hand, pulled out a gun with his right, and took a step forward, holding the gun extended at shoulder level. He said, "Give me all your money or I'll blow your head off." [I thought] about shooting but wanted to give Johnson an opportunity to end it. I withdrew my

\footnotetext{
${ }^{43}$ The Portland Observer quoted the officers as using MF, but using the actual profanity instead of the acronym.

44 "Police Killing Justified."

${ }^{45}$ Ibid.

${ }^{46}$ Ibid.
} 
pistol, pointed at Mr. Johnson, and said, "Police, drop the gun." Johnson looked at the gun, then at me, stood for a few seconds, sidestepped to his right, near the opening to the dining room-kitchen. He then stooped into a crouch, turned to his right toward the doorway. He was still pointing the gun. I felt like I had waited too long for my own protection. I thought I was going to be shot. Thought he was going back, was going to shoot. ${ }^{47}$

Sanford then testified that he fired two rapid shots and was unsure which bullet hit Johnson. Moore did not ask any follow up questions and did not ask the questions the black community requested, such as why Sanford "shot to kill; how the bullet struck the back of the head; or why he shot into the street after Zachery when he knew other officers were there to apprehend him. ${ }^{48}$ The crowd watching from the county commission chamber often broke into hostile muttering and shouting while Sanford testified. ${ }^{49}$ Citizens attending the inquest expressed their resentment towards Sanford and the Portland police openly. After the assistant district attorney questioned Sanford, the sixperson jury voted as to whether Sanford should be held accountable. The vote returned five to one that Sanford's actions were justifiable. The only black jury member casted the sole vote against Sanford's innocence. ${ }^{50}$

\footnotetext{
${ }^{47}$ Ibid.

48 "Police Killing Justified."

${ }^{49}$ Richards, "Hundreds of Spectators Jam Hearing into Shooting Shooting by Officer."

50 "Black Student Union in the Black Community"; "Can't Hide Problems," The Portland Observer, May 1, 1975, Acc. A2001-022, PARC; Vernon Jordan, "Police Violence Serious Problem," Portland Observer, April 3, 1975, Portland Observer Microfilm: Reel 2, Oregon Historical Society.
} 


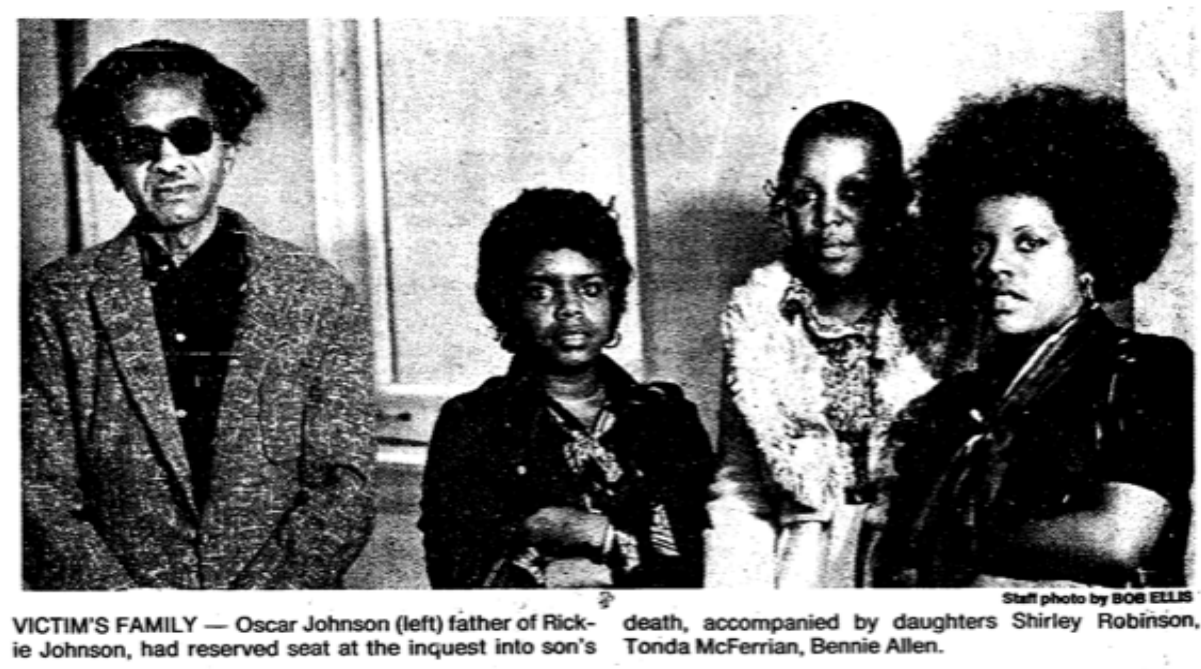

Figure 10: Rickie Johnson's family at the public inquest. Source: Richards, "Hundreds of Spectators Jam Hearing into Shooting Shooting by Officer."

Although the public inquest was meant to provide the Portland community with the details of the incident, The Observer was the only media outlet to report on and quote the testimonies of the witnesses. After the inquest, the city of Portland charged $\$ 180$ for a copy of the transcript. Even after requesting a copy, the Department of Justice refused to provide community members with a copy of the transcript. ${ }^{51}$ The Observer's thorough depiction of the inquest gave community members valuable information surrounding the case that could not be obtained elsewhere.

Reactions to the results of the public inquest varied; some community members felt the jury came to their conclusions without bias, whereas other Portland citizens felt the inquest was simply a facade to quell racial unrest. Members of the black community were not surprised by the outcome of the public inquest. Artharee from the BJC explained the group was disappointed but not surprised. He stated: “[The inquest's

${ }^{51}$ Albina Coalition Meeting Notes, April 23, 1975, Acc. A2001-022, PARC. 
verdict was] consistent with what we expected in light of [Portland] history." ${ }^{.52}$ Members of the black community agreed that the public inquest was a whitewash: In his zine, Lucien Loiseau contended that the inquest was "a typical example of cover up for the wrong deeds of killers who wear police uniform" and that jury selectors systematically ignored minorities and poor whites in Portland. Black activists felt the city purposely excluded hard-hitting questions that might jeopardize the validity of the officer's testimony. The city did not ask nor did the PPB explain why they used this specific procedure, how the bullet hit Johnson in the back of the head, why Johnson's body fell ten feet away from his gun, and why Sanford shot into the street at Zachery-all of which were questions originally requested by the BSU. Members of the black community and those that sympathized with the black activists believed the public inquest was necessary, but completely whitewashed. When asked his opinion of the verdict, NAACP President Reverend Ellis Casson responded: "I disagree with it." When asked why he disagreed, Casson simply stated, "I just don't think it was right.",53

Portland State University's BSU felt that the inquest had failed to answer the important questions pertinent to the case. The BSU argued that there were no opportunities for anyone but Assistant District Attorney Moore to ask questions, and the community felt that Moore did not ask all the questions he should have. ${ }^{54}$ Despite their hopes and efforts, Ujima editor Charlotte Rutherford - also the founding member of the BJC—reported:

\footnotetext{
${ }^{52}$ KOIN News, "Civil Rights KOIN News Pull."

${ }^{53}$ Ibid.

54 "Black Student Union in the Black Community"; Colin Dennis, "No Time to Learn," The Oregonian, April 7, 1975, Editorial edition.
} 
The inquest did not answer all of the questions felt to be pertinent to the case. There was no opportunity for anyone other than [Assistant District Attorney] Moore and the jurists to question witnesses and many questions were left unasked and unanswered. ${ }^{55}$

Although unhappy with the results, the community was not surprised. Based on previous experiences with police violence, few believed the inquest would find Sanford anything but innocent.

Similarly, Mayor Goldschmidt, Police Chief Baker and District Attorney Haas were not surprised by the results of the public inquest. However, the differences between these responses are important. The black community expected the jury to vote in favor of Sanford's innocence due to the strength of the Portland Police Association and based on the history of race relations in Portland. Police brutality against the African American community was almost always viewed as justifiable by white Portlanders, so it was unsurprising when the nearly all-white jury decided on Sanford's innocence. Conversely, Goldschmidt, Baker, and Haas had expected that the jury would find Sanford innocent for different reasons. They were confident that the community would side with the police, because they themselves were confident in police practices and behavior. ${ }^{56}$ After the public inquest, Chief Baker wrote a commendation letter to Sanford praising him for his demeanor on the night of Johnson's death and during the public inquest. Baker described Sanford's actions as "a selfless devotion to duty" and argued that Sanford's behavior "was exemplary and

\footnotetext{
${ }^{55}$ Ibid.

${ }^{56}$ Neil Goldschmidt to Letter to Lloyd Minter, April 1, 1975, Acc. A2001-022, PARC. Before the inquest even happened, Goldschmidt wrote to a local citizen and insured that the inquest would find Sanford innocent. "Based on what I know, I believe the inquest will demonstrate that Officer Sanford acted correctly."
} 
should serve as a model for all persons who are sworn to serve and protect the

public.", 57

Although the Police Bureau supported Sanford, Mayor Goldschmidt still felt the need to support all groups involved. His public response was both calculated and neutral in an attempt to quell tensions within Portland communities. Goldschmidt wrote, "I believe that the inquiry was a fair and proper proceeding, and I have accepted its conclusions; nevertheless, I think we share a concern that both the police and the community learn from the incident." ${ }^{, 58}$ In this statement, Goldschmidt did not completely support the black community, but also did not alienate the community, so he remained impartial. His response to the Johnson killing stymied any attempts to regulate police firearm use.

\section{Conclusion}

Officer Sanford's public inquest acted as a facade of transparency for Portland politicians. It instigated community conversation, yet no police reform emerged from the process. Because the inquest was carried out, Police Chief Baker, District Attorney Haas, and Mayor Goldschmidt were able to say the city had listened to the grievances of the activists without actually committing to any amelioration. ${ }^{59}$ Additionally, varied

\footnotetext{
${ }^{57}$ Bruce Baker to Kenneth Sanford, April 3, 1975, Acc. A2003-001, PARC.

${ }^{58}$ Goldschmidt to Minter, April 1, 1975; Neil Goldschmidt to Mr. and Mrs. Donald Van De Bogart, April 8, 1975, Acc. A2001-022, PARC; Neil Goldschmidt to Patricia Knight, April 1, 1975, Acc. A2001-022, PARC. Throughout these letters to citizens, we see Goldschdmidt's contradictory responses. To citizens who complained about the PPB, he defends the Portland police. To those who complained about the black activists, he defends the African American community and their advocacy efforts. His responses are calculated and precise, and are meant to quell unrest from Portland citizens.

${ }^{59}$ Sanford was sentenced to a ten day suspension on May 20, 1975, for Rickie Johnson's death. He asked Chief Baker to modify his punishment to a three day suspension and seven days taken out of his vacation
} 
responses from the general community negated any substantial reform as the Portland community and political community were divided in their opinions. Thus, the community's non-unified response to Johnson's death by Officer Sanford confirmed the power and untouchable nature of the Portland Police Bureau.

Despite the results of the inquest, the inquest in itself was a victory of sorts for the black community and acted as an acknowledgement of officer wrongdoings. Not since Ervin Jones' death in 1945 had a police officer been publically questioned in an inquest about the death of a black citizen. Additionally, Sanford's public inquest was the first under the district attorney, which put added legal weight behind the inquest and therefore pushed for Sanford's accountability. The result of the inquest was not because of activist insufficiencies, but instead revealed the power of operational racism within the city of Portland. Although the jury found Sanford's actions justifiable, the black community was still successful in pressing their demands for a public inquest and for opening up the issue of police accountability.

Rickie Johnson's death and the inquest that followed drew interest beyond Portland. Citizens across the United States wrote to Reverend Casson, President of the Portland NAACP, to voice support or disdain for the inquest. The majority of the personal letters to Casson and the NAACP supported its efforts and were sympathetic. Several suggested that Casson and other members of the black community sue Officer

and pension. Baker wrote to Goldschmidt in support, and Goldschmidt signed off on the modified punishment. The reasoning behind this was that Sanford had suffered "severe financial loss" because of the situation and could not afford more financial hardship. See Neil Goldschmidt to Kenneth Sanford, May 26, 1975, Acc. A2014-04, PARC; Bruce Baker to Neil Goldschmidt," May 20, 1975, Acc. A2014-04, PARC; Kenneth Sanford to Chief Baker, May 20, 1975, Acc. A2014-04, PARC. 
Sanford and the PPB for one million dollars. P.J. Cowan of Newark, New Jersey, suggested that a lawsuit was the only way to seek justice against "sadists and killers with badges. ${ }^{, 60}$ P.J. De Motti, also of New Jersey, encouraged Casson to sue the police but to keep in mind that winning the suit was not what was most important. The fact that the police would have to answer in front of a federal court would hopefully "make them rethink their attitudes and policies. ${ }^{.61}$ If the black community decided to not press further charges on these injustices, police officers would continue get away with similar atrocities.

Black activists did not file a lawsuit, but instead pursued a federal investigation into Portland's police brutality. After Sanford's public inquest, the Albina Ministerial Alliance and the Portland NAACP met with Chief Baker and Mayor Goldschmidt and demanded a federal investigation into the killings of Johnson, Menefee, Allen and Hopkins. ${ }^{62}$ Oregon's U.S. Attorney Sidney Lezak decided during a preliminary investigation that a federal investigation was not necessary because Lezak was unable to find evidence to support the notion that Johnson's death was a part of a larger pattern of civil rights injustices carried out against the black community by the Portland police. ${ }^{63}$

\footnotetext{
${ }^{60}$ PJ Cowan to Ellis Casson, n.d., in Box 19, National Association for the Advancement of Colored People (NAACP) Portland Branch records 1950-1970, University of Oregon Special Collections.

${ }^{61}$ PJ De Motti to Ellis Casson, n.d., in Box 19, National Association for the Advancement of Colored People (NAACP) Portland Branch records 1950-1970, University of Oregon Special Collections.

${ }^{62}$ William Taylor to Albina Coalition, May 23, 1975, Acc. A2001-022, PARC; "Officials Meet Blacks," The Oregonian, April 16, 1975.

63 "Lezak Rules out Jury Probe of Shooting Deaths," The Oregonian, September 19, 1975; "Black Student Union in the Black Community,"; "Blacks Dissatisfied with Death Probe," The Oregonian, September 19, 1975,16. Although upset with this conclusion, members of the black community believed Lezak was an "honest man," and that the evidence was "just not there." Jim Brooks, Executive Director of the Urban League of Portland, said that the results of the investigation were not what was most important. Brooks stated, "Challenging this process with diligence and integrity is most important for the black community, we must demonstrate we are alert and learn that the system can work for us just as for anybody."
} 
While Lezak questioned the notion that widespread police injustice existed, another Portland youth succumbed to death by gunfire. Similar to Rickie Johnson, Zebedee Manning was a black teenager who died under suspicious circumstances involving the Portland police. In September of 1975, investigators found Manning on his back with his arms folded across a rifle and with a bullet hole in the center of his forehead. The PPB reported Manning's death a suicide. However, Manning was shot with a sawed off 22 caliber rifle; if he put the gun to his head, his arms were not long enough to pull the trigger himself. ${ }^{64}$ Additionally, detectives found four drinking glasses and two empty whiskey bottles in the kitchen; thus insinuating that Manning had guests over the night he died. ${ }^{65}$

Although the PPB insisted that Manning had committed suicide, members of the black community—and even a few members of the bureau—believed Manning was a victim of homicide. Furthermore, concerned community members suspected that Manning was a victim of a police drug bust gone awry. Manning's brother-in-law, Henry Johnson, was one of Portland's most notorious heroin dealers. Police arrested Johnson two weeks before Manning's death. At the time, the Portland Police Narcotics Division had a reputation for being drug users themselves. ${ }^{66}$ Detective Don Dupay described officers as using heavy amounts of cocaine before they'd go out on raids. Some members of the Portland community believed that the police knew Henry Johnson left his heroin

\footnotetext{
${ }^{64}$ Don Dupay, Behind the Badge in River City (Portland, Oregon: Oregon Greystone Press, 2015).

${ }^{65}$ Phil Sanford, "75 Case Deserves Another Look," Portland Tribune, May 8, 2006, http://portlandtribune.com/component/content/article?id=98312; Theresa Kennedy, "A Remembrance of Police Work: Owning the Forgotten. Interview with Don Dupay," April 23, 2011, http://web.pdx.edu/ kennedyt/don_dupay_interview.html.

${ }^{66}$ Dupay, Behind the Badge in River City.
} 
stash with Manning, and therefore went to bust Manning and retrieve the drugs. After getting him drunk and attempting to intimidate him, some citizens and even officers believed that an officer of the Narcotics Division shot and killed Zebedee Manning out of frustration or greed. Manning's mother eventually found Johnson's heroin stash in her son's crawl space. She flushed the drugs down the toilet. A week after Manning's death, she received a call from a person with a "white man's voice. ${ }^{, 67}$ The caller demanded she call off the police investigation unless she "wanted more family members dead.",68 Detective Dupay continued to investigate Manning's death. He submitted a report to the police chief on his suspicions and his findings. Years later when Dupay attempted to acquire the report, the clerk told him the police had shredded the document years ago. ${ }^{69}$

Just six months after the death of Rickie Johnson, Manning died. That same month, U.S. Attorney Lezak determined there was not enough evidence to proceed with a federal investigation into the PPB. Similar to Johnson's death, Manning's death elicited contradictory responses from the Portland community. Many members of the black community believed Manning's death was a police bust gone bad. Within a year, the city of Portland had witnessed the death of four black men by the Portland police, a preliminary federal investigation into police violations of civil rights, and at least one suspicious circumstance involving the death of a teenager with potential Portland police involvement. Despite the obvious need for police reform and additional community involvement, Portland city government and citizenry remained divided for generations to come.

\footnotetext{
${ }^{67}$ Sanford, "75 Case Deserves Another Look."

${ }^{68}$ Kennedy, "A Remembrance of Police Work."

${ }^{69}$ Dupay, Behind the Badge in River City.
} 


\section{Conclusion}

\section{The Legacy of Rickie Johnson's Death}

Rickie Johnson's death elicited strong reactions from young black activists in Portland. These black activists demanded a public inquest to investigate Johnson's death, but due to the nearly all white jury and white-dominated city government, Officer Sanford was found not guilty and no charges were brought against him. The death of Johnson hit many Portland citizens close to home. Black community members had witnessed decades of police brutality within Portland's communities of color, and Johnson was the fourth young black man to be shot and killed by Portland police within a five-month period. So quite literally, Johnson's death hit close to home as many black activists and citizens knew the victims or were victims of police brutality themselves. Johnson's death, his age, and the controversial circumstances surrounding the case created doubt within white communities and hindered their reliance on the PPB.

Several aspects of this thesis research remain a mystery. I have never found a police or incident report from the night of Johnson's death, and I have never found a transcript of Sanford's public inquest. ${ }^{1}$ However, the biggest mystery remains as to who exactly Rickie Charles Johnson was. We know he was a junior at Washington High School in 1975, and we know his father owned several properties throughout Portland. ${ }^{2}$ We know he had siblings, and at least one friend. While researching the advocacy and subsequent attempted reform, I kept wondering about the details of Rickie Johnson's life

\footnotetext{
${ }^{1}$ Meeting notes from the April meeting of the Black Coalition stated the city would charge the committee $\$ 180$ for a copy of a transcript. The Justice Department and Human Resources Bureau refused to provide a copy to the committee. See "Albina Coalition Meeting Notes.".

${ }^{2}$ Burke and Jeffries, The Portland Black Panthers.
} 
and personality: What made him laugh; what was his favorite meal that his mom made; and always, what was he most afraid of?

Unlike Rickie Johnson, information about Officer Kenneth Sanford's life is available to view due to his personnel file at the Portland City Archives. Kenneth “Kenny” Eugene Sanford was born on October 8, 1946 in Portland, Oregon. In 1959, Sanford's parents moved the family to the Oregon coast and bought the Bonnie View Hotel in Nye Beach, Oregon. Sanford, the younger of two boys, graduated high school and followed in his father's footsteps by enlisting in the United States Navy. After serving in the Vietnam War, Sanford returned to Oregon and joined the PPB in $1968 .^{3}$ During the first year of Sanford's career, he was highly regarded by his peers and supervisors. Sanford was known for using sound common sense and handling calls without "sacrificing accuracy or thoroughness."4 Three years into the police force, supervisors continued to commend Sanford for his work on burglary duty. Specifically, they praised Sanford for "continuing attention to self improvement" and working in the "high incidence area" (North Portland) with consistency and courtesy. ${ }^{5}$

Prior to the incident with Johnson on North Gantenbein Avenue, supervisors and citizens in southwest and North Portland showered Sanford with praises for intercepting

\footnotetext{
${ }^{3}$ Appointments, Resignations and Oaths of Office, The Portland Police Bureau, Acc. A2014-004, PARC; “Obituary: Kenneth 'Kenny’ Eugene Sanford,” News Times, December 31, 2014, http://www.newportnewstimes.com/v2_news_articles.php?heading=0\&page=90\&story_id=46526. ${ }^{4}$ Portland Police Bureau, "Officer Performance Evaluation Report," April 1, 1969, Acc. A2014-004, PARC; John Jan, "Performance Evaluation Report," September 24, 1970, Acc. A2014-004, PARC; Peter Grant, "Skid Row Officer Likes His Work," The Oregon Journal, n.d; John Luciano to Kenneth Sanford, Commendation Letter, (April 16, 1974), Acc. A2014-004, PARC.

${ }^{5}$ Portland Police Bureau, "Officer Performance Evaluation Report," April 1, 1971, Acc. A2014-004, PARC; Chief’s Office, “1975 Memo PT PO \#89," May 13, 1975, S Acc. A2014-004, PARC; Chief's Office, “1969 Memo- PO PT \#2,” January 13, 1969, Acc. A2014-004, PARC.
} 
robberies, assisting injured citizens and helping those in need. ${ }^{6}$ Unique experiences include spontaneous mouth-to-mouth resuscitation for an elderly apartment resident, immediate response to a child's head injury and a river dive to recover a stolen cash register. ${ }^{7}$ Sanford's praises continued throughout the early 1970s; his one critique being that he often became "excitable in emotional situations." ${ }^{8}$ Sanford took pride in his rapport with the Portland community. He often volunteered for difficult or emotionally charged missions and was even a Volunteer Community Sponsor for the adult division of Multnomah County's Probation and Parole program. ${ }^{9}$ Sanford was twice called by Portland's SERT (Special Emergency Response Team) to diffuse a situation with an armed hostage. The suspect, Bruce Amick of North Portland, specifically requested Sanford's presence during the negotiations. ${ }^{10}$ The races of these citizens who acclaimed Sanford's behaviors are unknown.

War veteran and author Karl Marlantes described the act of killing: "Killing someone without splitting oneself from the feelings that the act engenders requires an effort of supreme consciousness that, quite frankly, is beyond most humans." ${ }^{11}$ After

\footnotetext{
${ }^{6}$ Portland Police Bureau, "Officer Performance Evaluation Report," April 1, 1969, Acc. A2014-004, PARC; John Jan, "Performance Evaluation Report," September 24, 1970, Acc. A2014-004, PARC; Portland Police Bureau, "Officer Performance Evaluation Report," April 1, 1971, Acc. A2014-004, PARC; Portland Police Bureau, "Officer Performance Evaluation Report," October 1, 1972, Acc. A2014-004, PARC; Portland Police Bureau, "Kenneth Sanford Officer Performance Report," April 7, 1972, Acc. A2014-004, PARC; "Performance Evaluation Report," September 15, 1972, Acc. A2014-004, PARC; Lynn Kirby Ford to Captain Bill Taylor, December 11, 1973, Acc. A2014-004, PARC.

${ }^{7}$ Clarence Armstrong to Kenneth Sanford, October 4, 1974, Acc. A2014-004, PARC; D.L Baker to Captain Reiter, July 14, 1975, Acc. A2014-004, PARC;

${ }^{8}$ Portland Police Bureau, "Officer Performance Evaluation Report," October 1, 1972.

${ }^{9}$ Katherine Zimmerman to Donald McNamara," January 5, 1973, Acc. A2014-004, PARC.

${ }^{10}$ Chief’s Office, "1975 Memo - PO PT \#84," April 28, 1975, Acc. A2014-004, PARC; Bruce Baker to Kenneth Sanford, April 4, 1977, Acc. A2014-004, PARC; "Man's Surrender Ends Standoff with Officers," The Oregonian, September 11, 1977; In one instance, Amick held his eight month old daughter hostage. Sanford first met Ammick after Sanford's police car window was shot out.

${ }^{11}$ Karl Marlantes, What Its Like to Go to War, (New York: Atlantic Monthly Press, 2011).
} 
Sanford shot and killed Johnson, friends report that Sanford changed. Frequently praised for his work with the community, official commendation letters decreased after 1975.

The Police Bureau suspended him in 1975 for accepting a gift from a citizen, and again in 1977 for use of intoxicants while off duty. ${ }^{12}$ In 1977, Sanford was put on permanent disability for Post Traumatic Stress Disorder. His wife left him, and he moved away from Portland. A friend and fellow North Precinct officer remembers that Johnson's death "ruined Kenny's life" and was a source of strife that Sanford never quite recovered from. ${ }^{13}$

The PPB's culture of resistance, supported by the PPA, negated Sanford's professional and moral accountability. PPA President Stan Peters claimed Sanford would receive psychological help after Johnson's death, yet there is no evidence that he did. ${ }^{14}$ To so easily brush aside Johnson's death as justifiable emphasized not only the inadequate services Portland police officers received from the bureau, but also the unspoken norm that black lives did not matter; this obviously and ultimately disrespected the sacredness of black lives throughout Portland and questioned the worth of black people.

In a Police Community Relations meeting immediately following Rickie Johnson's death, Norm Monroe, the Police Community Relations Administrative Assistant and black police officer, stated: "I think this tragedy could be a catalyst for a lot

\footnotetext{
${ }^{12}$ Bruce Baker to Kenneth Sanford, All Concerned, August 19, 1977, Acc. A2014-004, PARC; Bruce Baker to Kenneth Sanford, August 5, 1977, Acc. A2014-004, PARC; Portland Police Bureau, "Department Information," 1977, Acc. A2014-004, PARC.

13 "Integrated Full File: Kenneth E. Sanford" (Portland Police Bureau, 1979 1968), Acc. A2014-004, PARC; Ray Tercek (North Portland Police Officer), in conversation with the author, March 2016.

${ }^{14}$ KOIN News, "Civil Rights KOIN News Pull."
} 
of concern by people in the community, in the police bureau, in the city government- to take a look at all the programs, all the facilities, and all the activities that play an important part in not only a child's life but into the quality of the welfare of the community." ${ }^{, 15}$ Essentially, Monroe argued that citizens and city officials alike should turn Johnson's tragedy into a catalyst for change throughout Portland. Despite endless efforts of activists nationwide, police violence against people of color continues to plague the United States.

Just a few weeks into my first year of graduate school in October 2014, I was looking through the Verdell Burdine and Otto G. Rutherford Family Collection at Portland State University Special Collections and stumbled upon a zine from 1975 by activist Lucien Loiseau titled, "On the Murder of Rickey Johnson.” The zine detailed Johnson's death by Officer Kenneth Sanford and the visceral reactions of members of the black community. I read this zine that detailed the death of a young black man in 1975 less than a month after the death of Michael Brown in Ferguson, Missouri, by a white police officer, which caused nationwide unrest and demands for police accountability. Before Michael Brown there was Eric Garner, who died shortly after proclaiming, "I can't breathe.” Two months after I stumbled upon Rickie Johnson's story police killed another young black male. Tamir Rice was a twelve-year-old boy who was shot and killed while playing with a toy gun. Then came the death of Tanisha Anderson. Then, Sandra Bland. Even when recounting only those who've received media attention, the names are endless.

15 “PCR Mtg,” April 10, 1975, Acc. A2001-022, PARC. 
Even now, as I am writing this conclusion in March 2017, the city of Portland is under an investigation strikingly akin to that of Rickie Johnson. Seventeen-year-old Quanice Hayes was shot three times by a white Portland police officer because he was suspected of armed robbery. Disputed stories have surfaced on whether a fake gun was found near the body of Hayes. Officer Andrew Hearst, the man who killed Hayes, stated he "never saw Hayes with a gun but was trained not to wait to see one." ${ }^{\text {"16 }}$ Similar to the aftermath of Rickie Johnson's death, local young, militant activists-many from newly founded activist groups like Black Lives Matter and Hands Up Portland—have taken to the streets and to city council meetings to protest. They have been met with resistance from the police and mixed support from the community. Mayor Ted Wheeler has repeatedly told the protestors that justice will be sought for Hayes and his family. In 1975, Mayor Neil Goldschmidt also promised Oscar and Murlean Johnson justice after their son Rickie's death. Despite the protests, publicity, public inquest, and preliminary federal investigation, no immediate police reform occurred. The City of Portland, therefore, continued the longstanding national epidemic of police violence against people of color.

Police brutality continues to plague cities across the United States, including Portland, Oregon. Journalist Wesley Lowery stated in his 2016 book They Can't Kill Us All, "Before Ferguson, this story line was as common as it was hidden." $" 17$ The same can be said for Rickie Johnson. Prior to Johnson's death, the story of police shooting black

\footnotetext{
${ }^{16}$ Aaron Mesh, "The Portland Police Officer Who Shot Quanice Hayes," The Willamette Week, March 28, 2017, http:/www.wweek.com/news/city/2017/03/28/the-portland-police-officer-who-shot-quanice-hayesrecounts-the-killing-i-believed-it-was-my-responsibility/.

${ }^{17}$ Wesley Lowry, They Can't Kill Us All, (New York: Little, Brown and Company, 2016).
} 
citizens was common yet unmentioned within the mainstream white community. The death of Michael Brown in Ferguson, Missouri in August of 2014 instigated young activists to decry police brutality nationwide. Similarly, Rickie Johnson's death by Kenneth Sanford opened the eyes of local Portland citizens to the city's issues of police brutality. Prior to Johnson's death, the death of black men was just as common as it was confined to the Albina community. The death of seventeen-year-old Rickie Charles Johnson - like the death of Michael Brown in Ferguson — angered black citizens, local activists and caused uproar in the way in which media tracked these police killings.

Two days after the nation elected Donald Trump as president, I sat on a panel discussion for Portland's NAACP Black Legacy Project. The panel moderator asked, "What similarities can you draw between the recent election and your research?" I listed Trump's promotion of Stop and Frisk, which historically has lead to racial profiling and causes the majority of officer involved shootings; I talked about the country's most powerful police union backing the president elect; and I talked about his support of the Blue Lives Matter Movement. Lastly, I emphasized the untouchable nature of white men in power. Whether "power" is money, stature, or a police badge, the history of a white man's unassailability is ever present. In 1975, activist Baruti Artharee explained on the topic, "What we have here is a situation in reverse. We have the abuser telling the victim that it's okay. It's okay if I hit your head, it's okay if I shoot you in the back of your head." ${ }^{18}$ Historian Lawrence Friedman stated, "The history of criminal justice is not only the history of the forms of rewards and punishment.. It is also the history of power."19

\footnotetext{
${ }^{18}$ KOIN News, "Civil Rights KOIN News Pull."

${ }^{19}$ Lawrence Friedman, Crime and Punishment in American History, (New York: Basic Books, 1993).
} 
The advocacy surrounding the death of Rickie Charles Johnson by Officer Kenneth Sanford encourages contemporary activists to speak out against police brutality. At Quanice Hayes' funeral service in March 2017, his cousin gave a ten-minute eulogy about the life of his beloved relative, nicknamed Moose. He warned Portlanders of the epidemic of police brutality within the city. He stated, "People act like Portland is different, when it's not. At some point, enough brains need to be stacked for ya'll to see reality." ${ }^{20}$ While following Hayes' case, I constantly wondered: forty years since Rickie Johnson's death, and still this? Violence against people of color by police officers is as timeless as the invincibility of white men in power. Advocacy against atrocities performed by these men in power, however, is just as ever-present.

20 “Quanice Hayes' Cousin Delivers Eulogy at Funeral," The Oregonian, March 24, 2017, https://www.youtube.com/watch?v=-goiO3wPrwQ. 


\section{$\underline{\text { Secondary Sources }}$}

Abbott, Carl. Portland in Three Centuries: The Place and the People. Corvallis: Oregon State University Press, 2011.

Agyepong, Tera. "In the Belly of the Beast: Black Policemen Combat Police Brutality in Chicago, 1968-1983.” The Journal of African American History 98, no. 2 (n.d.): 253-76.

“Albina Ministerial Alliance (AMA) Coalition for Justice and Police Reform," n.d. http://www .albinaministerialcoalition.org/.

Anderson, Benedict. Imagined Communities. London and New York: Verso Publishing, 2006.

Balto, Simon Ezra. “'Occupied Territory': Police Repression and Black Resistance in Postwar Milwuakee, 1950-1968." The Journal of African American History 98, no. 2 (Spring 2013): 229-52.

Blee, Kathleen. "Reviewed Work: Behind the Mask of Chivalry: The Making of the Second Ku Klux Klan.” Contemporary Sociology 24, no. 3 (May 1995): 346-47.

Bogle, Kathryn Hall. "Kathryn Hall Bogle on the African-American Experience in Wartime Portland." Oregon Historical Quarterly 93, no. 4 (Winter -93 1992).

Boykoff, Jules, and Martha Gies. "We're Going to Defend Ourselves': The Portland Chapter of the Black Panther Party and the Local Media Response." Oregon Historical Quarterly 111, no. 3 (October 1, 2010): 278-311. https://doi.org/10.5403/oregonhistq.111.3.0278.

Boyle, Kevin, ed. "When the Ku Klux Klan Ruled Detroit." The Journal of Blacks in Higher Education, no. 47 (2005): 100-101. https://doi.org/10.2307/25073190.

Bryan, Joshua Joe. "Portland, Oregon's Long Hot Summers: Racial Unrest and Public Response, 196701968.” Dissertations and Theses, Portland State University, 2013.

Bryce, Herrington, ed. Black Crime: A Police View. Washington DC: Joint Center for Political Studies, 1977.

Burke, Lucas, and Judson Jeffries. The Portland Black Panthers. Seattle: University of Washington Press, 2016.

Burrough, Bryan. "Today, a Softer Response to Police Violence than in 1960s and '70s - LA Times," May 2, 2015. http://www.latimes.com/opinion/op-ed/la-oe-0503-burroughviolent-revolution-20150503-story.html.

Chandler, J. D. Murder \& Mayhem in Portland, Oregon. The History Press, 2013.

Chandler, J.D. "No Time to Learn.” Http://portlandcrime.blogspot.com/2016/08/no-time-tolearn_33.html. Slabtown Chronicle (blog), n.d.

Coates, Ta-Nehisi. Between the World and Me. New York: Spiegel and Grau, 2015.

Darby, Jody, Julie Perini, and Erin Yanke. Arresting Power, 2015.

Donnelly, Robert. Dark Rose. Seattle and London: University of Washington Press, 2011.

Donnelly, Robert C. "Organizing Portland: Organized Crime, Municipal Corruption, and the Teamsters Union.” Oregon Historical Quarterly 104, no. 3 (October 1, 2003): 334-65. http://www.jstor.org/stable/20615344.

- - - . "Organizing Portland: Organized Crime, Municipal Corruption, and the Teamsters Union.” Oregon Historical Quarterly 104, no. 3 (October 1, 2003): 334-65. http://www.jstor.org/stable/20615344. 
Dupay, Don. Behind the Badge in River City. Portland, Oregon: Oregon Greystone Press, 2015.

Emsley, Clive. Policing and Its Context, 1750-1870. New York: Schocken Books, 1984.

Finn, John. Wicked Portland. Charleston: History Press, 2012.

Friedman, Lawrence. Crime and Punishment in American History. New York: BasicBooks, 1993.

Gibson, Karen. "Bleeding Albina: A History of Community Disinvestment, 1049-2000." Transforming Anthropology 15, no. 1 (April 2007): 3-25.

_ _ _. "Bleeding Albina: A History of Community Disinvestment, 1940-2000." Transforming Anthropology 15, no. 1 (2007): 3-25.

Gies, Martha. "Black Panthers in Portland." The Oregon Encyclopedia. http://www.oregonencyclopedia.org/articles/black_panthers_in_portland/\#.VkpV_WSrTq Q.

Griffin, Anna, and Casey Parks. "Keaton Otis: Race, Mental Illness and a City's Lost Son." Oregon Live, August 4, 2014. http://www .oregonlive.com/keaton-otis/.

Hahn, Harlan. "Ghetto Assessments of Police Protection and Authority." Law \& Society Review 6, no. 2 (1971): 183-94. https://doi.org/10.2307/3052851.

Hall, Jacquelyn Dowd. "The Long Civil Rights Movement and the Political Uses of the Past." The Journal of American History 91, no. 4 (March 2005): 1233-63.

Hall, Simon. "Protest Movements in the 1970s: The Long 1960s." Journal of Contemporary History 43, no. 4 (2008): 655-72. http://www.jstor.org.proxy.lib.pdx.edu/stable/40543228.

Hauser, Susan. Pickets, Pistols and Politics. Portland: Portland Police Association, 1996.

Herzog, Mark, Tom Hanks, and Gary Goetzman. “Television Gets Real.” CNN's The Seventies, June 2015.

Hicks, Cheryl. Talk With You Like a Woman: African American Women, Justice, and Reform in New York, 1890 - 1935. Chapel Hill, N.C.: University of North Carolina Press, 2010.

Holley, Santi Elijah. “'Burn the Town Down': The Striking Similarities Between Portland's 1967 Race Riot and Our City's Current Relationship with People of Color." The Portland Mercury. June 21, 2017. http://www.portlandmercury.com/feature/2017/06/21/19105241/burn-the-town-down.

Holmes, Malcom, and Brad Smith. Race and Police Brutality: Roots of an Urban Dilemma. Albany, New York: New York Press, 2008.

Hornsby, Alton. "Black America.” A State By State Historical Encyclopedia, n.d.

Juris, Harvey, and Peter Feuille. Police Unionism. Lexington: Rowman and Littlefield, 1973.

Kelling, George, and Robert Kliesmet. "Police Unions, Police Culture, and Police Abuse of Force.” In Police Violence. New Haven: Yale University Press, 1996.

Kennedy, Theresa. "A Remembrance of Police Work: Owning the Forgotten. Interview with Don Dupay," April 23, 2011.http://web.pdx.edu/ kennedyt/don_dupay_interview.html.

Klockars, Carl. "A Theory of Excessive Force and Its Control.” In Police Violence. New Haven: Yale University Press, 1996.

Lansing, Jewel. Portland: People, Politics, and Power, 1851-2001. Corvallis: Oregon State University Press, 2003.

Lawrence, Regina. The Politics of Force. Los Angeles: University of California Press, 2000. 
"List of Shootings and Deaths 1992-2014." Portland Cop Watch (blog), February 23, 2015. www.portlandcopwatch.org.

McElderry, Stuart. "Building a West Coast Ghetto: African-American Housing in Portland, 1910-1960." The Pacific Northwest Quarterly 92, no. 3 (Summer 2001): 137-48.

McLagan, Elizabeth. A Peculiar Paradise: A History of Blacks in Oregon. Portland, OR: Georgian Press, 1980.

McLagan, Elizabeth. "The Black Laws of Oregon.” BlackPast.Org (blog). Accessed June 7, 2015. http://www.blackpast.org/perspectives/black-laws-oregon-1844-1857.

Millner, Darrell. "Blacks in Oregon." Oregon Encyclopedia, n.d. http://www.oregonencyclopedia.org/articles/blacks_in_oregon/\#.VOuimrDF9Ig.

Moore, Leonard. "Behind the Mask of Chivalry: The Making of the Second Ku Klux Klan." Journal of American History 82, no. 1 (n.d.): 320-21.

- - - Black Rage in New Orleans: Police Brutality and African American Activism from World War II to Hurricane Katrina. Baton Rouge: Louisiana State University Press, 2010.

Muhammed, Khalil Gibran. The Condemnation of Blackness: Race, Crime, and the Making of Modern Urban America. Cambridge: Harvard University Press, 2010.

Nelson, William. The Fourteenth Amendment: From Political Principle to Judicial Doctrine. Harvard University Press, 1998.

Olsen, Polina. Portland in the 1960s. Charleston: The History Press, 2012.

Petitt, Becky. Invisible Men: Mass Incarceration and the Myth of Black Progress. New York: The Russel Sage Foundation, 2012.

Porter, Eric. "Affirming and Disaffirming Actions." In America in the 70s. Lawrence, Kansas: University Press of Kansas, 2004.

"Preface.” In Police Violence. London: Yale University Press, 1996.

Purdy, Ruby. Rose City of the World. First Edition., 1947.

Purnell, Brian. "Freedom North Studies, the Long Civil Rights Movement, and TwentiethCentury Liberalism in American Cities." Journal of Urban History, March 2016. https://www.bowdoin.edu/faculty/bpurnell/pdf/purnell-review-freedom-north-studies.pdf.

Robbins, William G. "Walter Pierce (1861-1954).” The Oregon Encyclopedia, January 21, 2016.

https://oregonencyclopedia.org/articles/pierce_walter_1861_1954_/\#.WbaphkqGPqR.

Russell-Brown, Katheryn. The Color of Crime: Racial Hoaxes, White Fear, Black

Protectionism, Police Harassment, and Other Macroaggressions. New York: New York University Press, 1999.

Sanford, Phil. "75 Case Deserves Another Look." Portland Tribune, May 8, 2006. http://portlandtribune.com/component/content/article?id=98312.

Schechter, Patricia. "Ida B. Wells-Barnett and the Carceral State." presented at the History Faculty Publications and Presentations, Portland State University, 2012. http://pdxscholar.library.pdx.edu/hist_fac/16.

Schmidt, Brad. "Limited Voting Rights: Portland's Electoral System Loses under California Law Aimed at Ensuring Minority Representation.” Oregon Live, July 29, 2014. http://www.oregonlive.com/portland/index.ssf/2014/07/limited_voting_rights_portland.ht $\mathrm{ml}$. 
Scotton, Stan. “A History of the Portland Police with Concentration from 1870-1932.” Portland State University, 1970. Oregon Historical Society.

Self, Robert. American Babylon: Race and the Struggle for Postwar Oakland. Princeton, NJ: Princeton University Press, 2003.

Semuels, Alana. "The Racist History of Portland, the Whitest City in America." The Atlantic. July 22, 2016. https://www .theatlantic.com/business/archive/2016/07/racist-historyportland/492035/.

Serbulo, Leanne C., and Karen J. Gibson. "Black and Blue: Police-Community Relations in Portland's Albina District, 1964-1985." Oregon Historical Quarterly 114, no. 1 (April 1, 2013): 6-37. https://doi.org/10.5403/oregonhistq.114.1.0006.

Shaw, Peter. "Why Aren't There More Black People in Oregon?" Portland Occupier, November 12, 2012. http://www.portlandoccupier.org/2012/11/28/why-arent-there-moreblack-people-in-oregon/\#sthash.vx5VAzLV.dpbs.

Smith, Douglas A. "The Neighborhood Context of Police Behavior.” Crime and Justice 8 (1986): 313-41. http://www.jstor.org.proxy.lib.pdx.edu/stable/1147431.

Spivey, Donald. Fire from the Soul: The History of the African-American Struggle. Durham: Carolina Academic Press, 2003.

Springer, Frank. "A History of the Portland Police Association.” Portland, OR, n.d. Portland Police Museum.

Stanford, Bill. Portland Confidential. Portland: WestWinds Press, 2004.

Staples, Robert. "White Racism, Black Crime, and American Justice: An Application of the Colonial Model to Explain Crime and Race.” Phylon 36 (1975): 14-22.

Still, Ronald. Out of the Blue: From Rookie to Chief. La Quinta: Solana Publishing, LLC, 2007.

Taylor, Clarence. "Introduction: African Americans, Police Brutality, and the U.S. Criminal Justice System." The Journal of African American History 98, no. 2 (Spring 2013): 200204.

- - - "Introduction: African Americans, Police Brutality, and the U.S. Criminal Justice System." The Journal of African American History 98, no. 2 (n.d.): 200-204.

- - - "Race, Class and Police Brutality in New York City: The Role Fo the Communist Party in the Early Cold War Years." The Journal of African American History 98, no. 2 (Spring 2013): 205-25.

Taylor, Quintard. In Search of the Racial Frontier. New York: W. W. Norton \& Company, 1994.

Thompson, Heather Ann. "Why Mass Incarceration Matters: Rethinkin Crisis, Decline and Transformation in Postwar American History." The Journal of American History 97, no. 3 (December 2010): 703-34.

Torny, Michael. Punishing Race: A Continuing American Dilemma. New York: Oxford University Press, 2011.

Tracey, Charles Abbott. The Evolution of the Police Function in Portland, Oregon 1811-1874, 1976.

Vick, Karl. “Seven Lives Lost and a New Reckoning on Race.” Time, July 25, 2016.

Walker, Bela August. "The Color of Crime: The Case against Race-Based Suspect Descriptions." Columbia Law Review 103, no. 3 (April 2003): 662-88. 
Watson, Dwight. Race and the Houston Police Department, 1930-1990: A Change Did Come. Houston: Texas A\&M University Press, 2005.

West, Elliott. "Reconstructing Race.” The Western Historical Quarterly 34, no. 1 (April 1, 2003): 6-26. https://doi.org/10.2307/25047206.

"What Is the Long Civil Rights Movement." Triangle Research Libraries Network (blog), http://www2.trln.org/ccc/context.htm.

\section{Primary Sources}

“1975 Memo - P.O. - P.D \#6,” May 7, 1975. Acc. A0237-01. PARC.

Albina Coalition. "Albina Coalition Meeting Notes," April 23, 1975. Acc. A2001-022. PARC. "Answering for a Life." The Oregonian. March 27, 1975, sec. Editorial/Letters.

"Area Defense on Full Time." The Oregonian, December 8, 1941.

Armsbury, Charles. "Letter to Ellis Casson from Charles Armsbury," n.d. Box 19. Box 19, National Association for the Advancement of Colored People (NAACP) Portland Branch records 1950-1970, University of Oregon Special Collections.

Armstrong, Clarence. "Letter to Kenneth Sanford," October 4, 1974. Acc. A2014-004. PARC. Bailey, Beth, and David Farber. "Introduction." In America in the Seventies. Lawrence, Kansas: University Press of Kansas, 2004.

Baker, Bruce. "Letter to All Concerned," April 23, 1975 Acc. A2001-022. PARC.

- - - ."Letter to All Concerned," May 27, 1975. Acc. A2014-004. PARC.

- - - ."Letter to Esther Nichols," April 25, 1975. Acc. A2014-004. PARC.

- - - "Letter to Kenneth Sanford," April 3, 1975. Acc. A2014-004. PARC.

- - - ."Letter to Kenneth Sanford," April 4, 1977. Acc. A2014-004. PARC.

- - - ."Letter to Kenneth Sanford," August 5, 1977. Acc. A2014-004. PARC.

- - - . "Letter to Kenneth Sanford, All Concerned," August 19, 1977. Acc. A2014-004. PARC.

- - - "Letter to Mrs. Better Lou Overton from Police Chief Baker," March 15, 1975. Acc. A2014-004. PARC.

- - - . "Letter to Neil Goldschmidt," May 20, 1975. Acc. A2014-004. PARC.

Baker, Bruce, and Wayne Sullivan. "Letter to Neil Goldschmidt," December 12, 1975. Acc. A0237-01. PARC.

Baker, D.L. "Letter to Captain Reiter," July 14, 1975. Acc. A2014-004. PARC.

Bauer, Maria. "Sadly Disillusioned." The Oregonian, May 28, 1985, sec. Letters to the Editor. Bayless, Marlene. "Memo to Vern Summers," May 8, 2016. Acc. A2001-022. PARC.

Bernstein, Maxine. "Baruti Artharee Says His Personal Experiences Will Shape His New Job as Mayor Hales' Public Safety Policy Director." OregonLive The Oregonian, January 22, 2013.

_- - . "Man Killed by Police Unarmed." The Oregonian, March 30, 3004. http://blog.oregonlive.com/washingtoncounty//print.html?entry=/2008/01/sery.html. 
- - - . "Multnomah County Grand Jury Does Not Indict Officer in Aaron Campbell Shooting." Oregon Live, n.d.

http://www.oregonlive.com/news/index.ssf/2010/02/multnomah_county_grand_jury_do.h tml.

- - - "Officers Will Face a Public Inquest," March 31, 2004. http://blog.oregonlive.com/washingtoncounty//print.html?entry=/2008/01/sery.html.

Black Coalition. "Letter to Neil Goldschmidt," April 24, 1795. Box 19. National Association for the Advancement of Colored People (NAACP) Portland Branch records 1950-1970, University of Oregon Special Collections, Portland Branch.

"Black Coalition Members List," n.d. In Box 19, National Association for the Advancement of Colored People (NAACP) Portland Branch records 1950-1970. University of Oregon Special Collections.

"Black Justice Committee Demands FBI Investigate Police Killings." Portland Observer, April 17, 1975.

"Black Justice Committee Members," March 24, 1975. Acc. A2004-005. PARC.

"Black Justice Committee: Positions," March 24, 1975. Acc. A2004-005. PARC.

"Black Leaders Seek Large Turn out at Inquest." The Oregonian. April 1, 1975.

"Black on Black." Portland Observer, October 2, 1975. In Box 7. Verdell Burdine and Otto G. Rutherford Family Collection, 1900-1980s.

"Blacks Ask Information for Inquest." The Oregonian, March 30, 1975.

"Blacks Claim 'Oppossums' Another Insult by Police.” Oregon Journal, n.d.

"Blacks Dissatisfied with Death Probe." The Oregonian, September 19, 1975.

"Black Students Protest Killing." Portland Observer, March 27, 1975. Portland Observer Microfilm: Reel 2. Oregon Historical Society.

"Black Student Union in the Black Community." Ujima 1, no. 3 (Spring 1975): 8. In Box 8. Verdell Burdine and Otto G. Rutherford Family Collection, 1900-1980s. Portland State University.

Boehmer, Gabriel. "Police Step up Minority Hirings.” The Oregon Journal, July 23, 1981. In "Police and Blacks" Folder. Darrell Millner's Personal Collection.

Boles, J. "Blacks and the Police in Portland." The Observer, July 3, 1980. In "Police and Blacks" Folder. Darrell Millner's Personal Collection.

"From Ferguson to Portland: Stop the Police Killing of Black and Poor People." The Portland Radicle (blog), November 24, 2014. https://portlandradicle.wordpress.com/2014/11/24/from-ferguson-to-portland-stop-thepolice-killing-of-black-and-poor-people/.

"Boycott Radio Cab Co!" The Portland Observer, April 25, 1975.

Buell Jr, Thomas. "Portlanders Seek a City Hall Overhaul." Street Roots, July 6, 2016. http://news.streetroots.org/2016/07/06/portlanders-seek-city-hall-overhaul.

Cabirac, Henry. "Letter to Kal Szeckely," July 2, 1975. Acc. A2001-022. PARC.

"Can't Hide Problems." The Portland Observer, May 1, 1975. Acc. A2001-022. PARC.

Casey, Jerry. "Previous Stories about Jason Sery and the Death of James Jahar Perez." Oregon Live, January 15, 2008. http://blog.oregonlive.com/washingtoncounty//print.html?entry=/2008/01/sery.html. 
"Charlotte B. Rutherford, Esq, Director, Black Women's Employment Program, NAACP Legal Defense and Educational Fund, INC.” Business Card, n.d. In Box 7. Verdell Burdine and Otto G. Rutherford Family Collection, 1900-1980s. Portland State University.

Cheifs Office. "1969 Memo- PO PT \#2,” January 13, 1969. Acc. A2014-004. PARC. Chief's Office. "1975 Memo - PO PT \#84," April 28, 1975. Acc. A2014-004. PARC.

_- - . "1975 Memo PT PO \#89," May 13, 1975. Acc. A2014-004. PARC.

- - - . "Personnel Order 79-95P," September 20, 1979. Acc. A2014-004. PARC.

"Chinese in Oregon." Accessed November 30, 2015. http://www.ccrh.org/comm/umatilla/primary/chinese.htm.

City Club of Portland. "Law Enforcement in Portland and Multnomah County," February 20, 1948.

http://members.pdxcityclub.com/HigherLogic/System/DownloadDocumentFile.ashx?Doc umentFileKey=5e9e4ed2-7ea9-4103-948f-45beefb66a3b\&forceDialog=0 .

- - - . "Report on Law Enforcement in the City of Portland." Portland, OR, August 30, 1968.

- - - . "Report on Ordinance Establishing a Police Internal Investigations Auditing Committee (City of Portland Measure No. 51)." Portland, OR, October 29, 1982.

- - - ."Report on the Negro in Portland: A Progress Report 1945-57." Portland, April 19, 1957.

http://ir.library.oregonstate.edu/xmlui/bitstream/handle/1957/12312/PortlandCityClubBul letinNegroPortland.pdf;jsessionid=5645BA30392F6311D62A88959519B893? sequence= 1 .

City of Portland, OR Police Bureau. "Request for Proposal: Conduct A Cultural Diversity Training Program.” 1991. In “Police and Blacks" Folder. Darrell Millner’s Personal Collection.

"City Organizes Blacks." The Portland Observer. n.d. Acc. A2001-022. PARC.

Coco, Sebastian. "We're the Oldest." The Rap Sheet, October 1974.

Collins, Huntly. "Albina Ministers, Mayor Discuss Police Changes." The Oregonian. March $28,1975$.

Constantine, Severe. "Quarterly Report: Independent Police Review,” Third quarter. http://www.portlandonline.com/auditor/index.cfm?c=40870\&a=518522.

"Constitution of the Black Justice Committee," n.d. In Box 7. Verdell Burdine and Otto G. Rutherford Family Collection, 1900-1980s. Portland State University.

Cosby, R.C. "Intelligence Report: Militants at Residential Manpower Center.” Police Report. Portland: Department of Public Safety Bureau of Police, August 19, 1970. Acc. A2004005. PARC.

Cosby, R.C. "Intelligence Report: Possible Racial Problem in Williams Avenue Area." Portland: Department of Public Safety Bureau of Police, July 25, 1968. Acc. A2004-005. PARC.

Cowan, PJ. "Letter to Ellis Casson from PJ Cowan, Neward, NJ," n.d. In Box 19, National Association for the Advancement of Colored People (NAACP) Portland Branch records 1950-1970, University of Oregon Special Collections. 
“Damages Sought for Death.” The Oregonian, March 2, 1975. In “Rickie Johnson” Folder. Darrell Millner's Personal Collection.

Delman, Berta. "Letter from Berta Delman to Neil Goldschmidt," December 30, 1975. Acc. A0237-01. PARC.

_ - _. "Letter to Neil Goldschmidt," April 12, 1975. Acc. A0237-01. PARC.

De Motti, PJ. "Letter to Ellis Casson," n.d. In Box 19. National Association for the

Advancement of Colored People (NAACP) Portland Branch records 1950-1970.

University of Oregon Special Collections.

Dennis, Colin. "No Time to Learn." The Oregonian, April 7, 1975, Editorial edition.

"District Attorney to Conduct Public Inquest into Perez Shooting." Portland Communique, March 30, 2004.

http://communique.portland.or.us/04/03/district_attorney_to_conduct_public_inquest_int o_perez_shooting.

Duin, Steve. "Reinstated with Back Pay." The Oregonian, February 27, 1997. In "Police and Blacks" Folder. Darrell Millner's Personal Collection.

"Educators Announce Strike End." The Oregonian. May 11, 1970.

Ford, Lynn Kirby. "Letter to Captain Bill Taylor,” December 11, 1973. Acc. A2014-004. PARC.

George, James. "Letter to Neil Goldschmidt," March 24, 1975. Acc. A0237-01. PARC.

Gervais, Kenneth. The Portland Police Officer. Claremont Graduate School and University Center, 1976.

Goldschmidt, Neil. "Letter to Berta Delamn,” December 30, 1975. Acc. A0237-01. PARC.

- - - "Letter to Hugh Havercamp," April 7, 1975. Acc. A0237-01. PARC.

- - - ."Letter to James George," March 31, 2016. Acc. A0237-01. PARC.

- - - . "Letter to Kenneth Sanford," May 20, 1975. Acc. A2014-004. PARC.

- - - ."Letter to Kenneth Sanford," May 26, 1975. Acc. A2014-004. PARC.

- - - "Letter to Lloyd Minter," April 1, 1975. Acc. A0237-01. PARC.

- - - ."Letter to Mr. and Mrs. Donald Van De Bogart," April 8, 1975. Acc. A0237-01. PARC.

— - - ."Letter to Patricia Knight," April 1, 1975. Acc. A0237-01. PARC.

Goodman, Elvin. "Letter from Mayor Elvin C. Goodman to Mayor Neil Goldschmidt,"

December 22, 1975. Acc. A0237-01. PARC.

Grant, Peter. "Skid Row Officer Likes His Work." The Oregon Journal, n.d.

Guernsey, John. "Protest March Proceeds Calmly, Marred Only By Flag Incident." The Oregonian, May 8, 1970.

_ - _. "War, Nerve Gas Protesters Arrested." The Oregonian. June 7, 1970.

Haas, Harl. "Letter to Neil Goldschmidt," March 24, 1975. Acc. A0237-01. PARC.

- - - . "Letter to the Honorable Neil Goldschmidt," March 25, 1975. Acc. A2001-022.

PARC.

"Haas Sets Inquest Date in Shooting." The Oregonian. March 27, 1975, sec. Editorial.

"Haas to Arrange Inquest into Shooting." The Oregonian. March 26, 1975.

Halverson, G.B. “Special Memorandum May 13, 1970," n.d. In Sub-Series 7. President's Office Records. Portland State University Special Collections. 
Harper, Austin. "Letter to Robert Lamb," April 14, 1975. Acc. A2001-022. PARC.

"Harry M. Niles." Portland Police Museum \& Historical Society. Accessed December 1, 2015. http://www.portlandpolicemuseum.com/harry-m-niles.html.

Havercamp, Hugh. "Letter to Neil Goldschmidt," April 2, 1975. Acc. A0237-01. PARC.

Hayakawa, Alan. "12 Shots Fired in Gun Battle That Killed Man." The Oregonian. November 22, 1974.

- - - ."Black Groups Granted Inquiry into Police Shootings." The Oregonian. March 23, 1975, sec. Editorials.

- - - ."Fellow Officers Help Pay Legal Bill." The Oregonian. May 16, 2015.

- - - . "Undercover Police Kill Suspect." The Oregonian, October 28, 1974.

- - - . "Undercover Police Kill Suspect." The Oregonian, October 28, 1974.

Heinz, Spencer. "Officer Plays Cabbie, Kills Youth in Holdup Try." The Oregonian, March 14, 2015.

- - - . "Police Confidence in Jordan Polled." The Oregonian, 1981. Acc. A2004-005. PARC.

- - - .Police Disparity Remains on Blacks Arrested." The Journal, March 23, 1982.

"Police and Blacks" Folder. Darrell Millner's Personal Collection.

- - - "Police Union Asks Jordan Be Removed." The Oregonian, April 9, 1981. Acc. A2004-005. PARC.

Hendericks, G, Ruth Hendricks, Donald Van de Bogart, and Lynda Van de Bogart. "Letter to Neil Goldschmidt," March 28, 1975. Acc. A0237-01. PARC.

Hill, James. "Zachery Pleads Guilty, Draws 7 Year Sentence.” The Oregonian, October 18, 1975.

Hill, Jim. "Blacks to Seek Shooting Inquest.” The Oregonian. 22975.

"History of the Portland Police Bureau I The City of Portland, Oregon." Accessed November 3, 2015. http://www.portlandoregon.gov/police/40004.

Hobart, Sue. "Black Youth Slain. DA to Call Inquest over Shooting." The Oregonian. March 23, 1975, Sunday Oregonian edition.

Hobley, Marcus. "Public Opinion Can Play a Positive Role in Policy Making." the Guardian, September 3, 2012. http://www.theguardian.com/public-leadersnetwork/2012/sep/03/public-opinion-influence-policy.

Hoover, Erin, and Nena Baker. "Police and Deadly Force: Looking for Middle Ground." The Oregonian, August 26, 1994.

Hunter, Susan. "The Coalition on Police/Community Relations," November 13, 1981. In "Police and Blacks" Folder. Darrell Millner's Personal Collection.

"Inquest Inadequate." Oregonian, April 4, 1975, sec. Editorial. Darrell Millner's Personal Collection.

"Inquest Jury Hears How Negro Died in Police Raid." The Oregonian, October 10, 1945.

"Integrated Full File: Kenneth E. Sanford.” Portland Police Bureau, 1979 1968. Acc. A2014004. PARC.

"Its First Session. Juvenile Court Will Be Convened Today." The Oregonian. June 10, 1905, sec. News/Opinion.

Jackson, William; PCR Chair Person. "Letter to MHRC Commission Members," May 14, 1975. Acc. A2001-022. PARC. 
Jan, John. "Performance Evaluation Report," September 24, 1970. Acc. A2014-004. PARC. Jenning, Steve. "Deadly Force Bill Said 'Gutted.” The Oregonian, July 24, 1981. In "Police and Blacks" Folder. Darrell Millner's Personal Collection.

Jordan, Vernon. "Police Violence Serious Problem.” Portland Observer, April 3, 1975. Portland Observer Microfilm: Reel 2. Oregon Historical Society.

"Jury Selection Begins in Robbery, Death Cases." The Oregonian. October 15, 1975.

"Justice Observes Killing Inquiry." Portland Observer, March 27, 1975. Portland Observer Microfilm: Reel 2. Oregon Historical Society.

"Kaiser Yards Launch Trio of Ships, Including Carrier." The Oregonian, November 23, 1943.

"Kenneth Sanford Officer Performance Report," April 7, 1972. Acc. A2014-004. PARC.

"Kenneth Sanford Performance Evaluation Report," October 1, 1974. Acc. A2014-004. PARC.

"Key Officials to Meet in Police Drug Probe." The Oregonian, May 11, 1981. Police Misconduct News Clippings. Portland City Archives.

Knight, Patricia. "Letter to Neil Goldschmidt," March 17, 1975. Portland City Archives.

KOIN News. "Civil Rights KOIN News Pull," 1975. Oregon Historical Society. https://www.youtube.com/watch?v=jZkrR1dWdsg.

Krajicek, David. "Justice Story: Cop Kills Boy, 10 - NY Daily News,” March 11, 2012. http://www.nydailynews.com/new-york/justice-story-nypd-kills-boy-10-officeracquitted-murder-fired-force-article-1.1034120.

"Let Citizens Audit Police." The Oregonian, October 15, 1982.

"Let Inquest Be Beginning." Oregon Journal, April 4, 1975.

"Letter to Attorney General Edward H. Levi from The Albina Coalition," April 24, 1975. Acc. A2001-022. PARC.

"Letter to Edward H. Levi, Attorney General from Black Coalition,” April 24, 1975. In Box 19. National Association for the Advancement of Colored People (NAACP) Portland Branch records 1950-1970. University of Oregon Special Collections.

"Lezak Rules out Jury Probe of Shooting Deaths." The Oregonian, September 19, 1975.

Loiseau, Lucien. "On the Murder of Rickey Johnson," 1975. In Box 7. Verdell Burdine and Otto G. Rutherford Family Collection, 1900-1980s. Portland State University.

Long, James. "Marked Drug Cash Linked to Police." The Oregon Journal, May 12, 1981. Acc. A2004-005. PARC.

Low, Robert J. "Letter from Low to Student Strikers," n.d. In Box 7. Verdell Burdine and Otto G. Rutherford Family Collection, 1900-1980s. Portland State University.

Luciano, John. Commendation Letter. "Letter to Kenneth Sanford." Commendation Letter, April 16, 1974. Acc. A2014- 004. PARC.

Lund, Eva. Oral History With Eva Lund. Oregon Historical Society.

Manning, Walton. "Letter to President Wolfe from Professor Manning," May 26, 1970. President's Office Records: Student Unrest. Portland State University Special Collections.

"Man's Surrender Ends Standoff with Officers." The Oregonian, September 11, 1977. Martin, Lloyd. "Letter to Neil Goldschmidt," March 27, 1975. Acc. A0237-01. PARC. McNamara, Donald. "Letter to Kenneth Sanford," February 20, 1970. Acc. A2014- 004. PARC. 
Mealey, Rich. “Albina Ministerial Alliance.” Accessed February 8, 2015.

http://www.blackpast.org/aaw/albina-ministerial-alliance-ca-1964.

"Memorandum Re: Shotguns/Police Bureau," March 20, 1975. Acc. A2014-004. PARC.

Metropolitan Human Relations Commission. "Minutes of Police Community Relations

Committee Meeting.” Portland, OR, June 9, 1975. Acc. A2001-022. PARC.

- - - "Minutes-- Police Community Relations," July 11, 1975. Acc. A2001-022. PARC.

- - _. "Police Community Relations Committee Meeting Minutes," May 7, 1975. Acc. A2001-022. PARC.

- - - . "Police Community Relations Committee Meeting Minutes," June 13, 1975. Acc. A2001-022. PARC.

Monroe, Norm. "PCR Meeting Notes," April 10, 1975. 30/9. Acc. A2001-022. PARC.

"NAACP Requests Inquest into Shooting Death." The Oregonian. March 20, 1975.

Nichols, Esther. "Letter to Kenneth Sanford," April 1975. Acc. A2014-004. PARC.

“Obituary: Kenneth 'Kenny' Eugene Sanford.” News Times. December 31, 2014. http://www.newportnewstimes.com/v2_news_articles.php?heading=0\&page=90\&story_i $\mathrm{d}=46526$.

"Officer Says Shot Fired to Save Partners on Raid." The Oregonian, October 11, 1945.

"Officials Meet Blacks." The Oregonian, April 16, 1975.

“'Operation Contact' The Church in the Streets." Action, October 1966. Acc. A2004-005. PARC.

Ota, Alan. "Black Front to Look into Police Brutality Charges." The Oregonian, November 8, 1979. Acc. A2001-022. PARC.

Painter, John Jr. "Police Seek to Recruit More Blacks." The Oregonian. 1994. In "Police and Blacks" Folder. Darrell Millner's Personal Collection.

"PCR Mtg," April 10, 1975. Acc. A2001-022. PARC.

"Performance Evaluation Report," September 15, 1972. Acc. A2014-004. PARC.

Peters, Stan. "Statement by Stan Peters to President Re Special Inquest," March 31, 1975 Acc. A0237-01. PARC.

"Picture Layout of Crime Scene." Portland Observer, April 3, 1975. Portland Observer Microfilm: Reel 2. Oregon Historical Society.

"Police Bears Burden.” Portland Observer, April 17, 2016. Portland Observer Microfilm: Reel 2. Oregon Historical Society.

"Police Bullet Kills Black Youth.” Portland Observer, March 20, 1975. Portland Observer Microfilm: Reel 2. Oregon Historical Society.

"Police Killing Justified, Black Juror Disagrees." The Portland Observer, April 3, 1975.

"Policeman Is Accused." Morning Oregonian, January 10, 1920.

"Police Minority Recruiters Predict Success." Portland Observer, September 18, 1975. Acc. A2001-022. PARC.

"Police Obtain Statement Thomas in Jones House." The Oregonian, October 14, 2016.

"Police Shoot Youth at Black Panther Office." The Oregonian, February 19, 1970.

"Police Unions." The Oregonian, April 16, 1942.

Portland (Or. ). Bureau of Police. Planning and Research Division. "A Job Analysis of the Position of Uniformed Police Officer.” Planning and Research Division, Portland Police Bureau, 1975. 
- - - . "A Job Analysis of the Position of Uniformed Police Officer." Planning and Research Division, Portland Police Bureau, 1975.

Portland Police Bureau. “Appointments, Resignations and Oaths of Office,” January 24, 1968. Acc. A2014-004. PARC.

- - - . "A Report to the Community: James Jahar Perez," November 2005. http://www.portlandoregon.gov/police/article/99881.

- - - ."Criteria for Site of Police Precinct," n.d. Acc. A2001-022. PARC.

- - - "Department Information," 1977. Acc. A2014-004. PARC.

- - - "Officer Performance Evaluation Report," October 1, 1072. Acc. A2014-004. PARC.

_ - - . "Officer Performance Evaluation Report," April 1, 1969. Acc. A2014-004. PARC.

- - - . "Officer Performance Evaluation Report," April 1, 1971. Acc. A2014-004. PARC..

- - - . "Special Meeting Notice," September 22, 1975. Acc. A2001-022. PARC.

"Portland Policeman Backed by Jury in Youth's Death." Unknown. n.d. In Box 19. National Association for the Advancement of Colored People (NAACP) Portland Branch records 1950-1970. University of Oregon Special Collections, Portland Branch.

"Practical Religion." The Oregonian, October 1, 1945.

"Probe Backed by Churches." The Oregonian, September 13, 1945.

"Probe Due Portland Shootings." The Oregonian. April 25, 1975.

"Protesters Hurt in Park Blocks Clash." The Oregonian, May 12, 1970, sec. A.

"Protest Parade Denied." The Oregonian, October 6, 1932.

Putnam, Keith. "Letter from Keith E. Putnam, Management Consultants," April 27, 1975. In

Box 19. National Association for the Advancement of Colored People (NAACP) Portland Branch records 1950-1970. University of Oregon Special Collections.

Reed, Watford. "Letter to Chief Baker," April 8, 1975. Acc. A2014-004. PARC.

Reiter, N.F. "Inter Office Memorandum: Model Precinct Concept," October 28, 1974. Acc. A2001-022. PARC.

Reiter, Norman. "Letter to Albina Coalition from Captain Norman Reiter," June 16, 1975. Acc. A2001-022. PARC.

- - - . "Participative Management Program Plan." Portland, OR: Portland Police Bureau, April 25, 1975. Acc. A2001-022. PARC.

"Report on Problems of Racial Justice in Portland," June 14, 1968.

Richards, Leverett. "Hundreds of Spectators Jam Hearing into Shooting by Officer." The Oregonian. April 3, 1975.

"Rickie Johnson Obituary." The Oregonian, March 18, 1975, 35.

Sanford, Kenneth. "Letter to Chief Baker," May 20, 1975. Acc. A2014-004. PARC.

- - - . "Letter to W. Chan," April 1, 1975. Acc. A2014-004. PARC.

Shinert, Gregory. "Letter to Kal Szeckely," July 15, 1975. Acc. A2001-022. PARC.

"Shooting Case Probe Asked." The Oregonian, October 13, 1945.

Snell, M.E. "Racial Expression,” n.d. In "Rickie Johnson” Folder. In Darrell Millner's Personal Collection.

"Squadron of Deputy Inspectors Go After Delinquents." Morning Oregonian, December 19, 1928.

“Statement of Stan Peters to Press; Special Inquest," March 31, 1975. Portland City Archives. 
"State of Oregon vs. Students," February 25, 1970. In Sub-Series 7: President's Office Records. Portland State University Special Collections.

"Summary Report of Police Action Review Committee Coalition on Police Community Relations," November 4, 1981. In "Police and Blacks" Folder. Darrell Millner's Personal Collection.

Summers, Vern. "Letter to Robert Lamb, U.S. Department of Justice," May 20, 1975. Acc. A2001-022. PARC.

Szeckely, Kalman. "Letter about Shotgun Policy," July 2, 1975. Acc. A2001-022. PARC. Taylor, William. "Letter to Albina Coalition," May 23, 1975. Acc. A2001-022. PARC. - - - . "Officer's Report," February 12, 1970. Acc. A2014-004. PARC.

- - - . "Sets Record Straight." The Oregonian, April 13, 1991, sec. Letter to the Editor. In "Black's and Police." Darrell Millner's Personal Collection.

Taylor, William S. "Sets Record Straight." The Oregonian. April 13, 1991, sec. Letter to the Editor. In "Police and Blacks" Folder. Darrell Millner's Personal Collection.

"Theft Admitted by Youth Whose Partner Police Shot." The Oregonian, May 17, 1975.

Trimble, C.F. "Intelligence Report: Sidewalk Demonstration." City of Portland, Oregon, Department of Public Safety: Bureau of Police, March 28, 1968. Acc. A2004-005. PARC.

"Trucker Harassed." The Oregonian. April 5, 1975.

Turner, Wallace, and William Lambert. "Hearings Set on Teamsters in Oregon." The Oregonian, December 6, 1956.

"Ujima." Ujima, January 1975. In Box 8. Verdell Burdine and Otto G. Rutherford Family Collection, 1900-1980s. Portland State University.

"Unnamed Letter to Ellis Casson," n.d. In Box 19. National Association for the Advancement of Colored People (NAACP) Portland Branch records 1950-1970. University of Oregon Special Collections.

Uris, Joe. "Portland State Strikers Sought Changed World." The Oregonian. May 6, 1990.

"U.S. Lease with the Port of Portland," September 11, 1944. The Port of Portland.

"Vern Summers Resigns from MHRC." The Skanner. May 20, 1976. In Box 12. Verdell

Burdine and Otto G. Rutherford Family Collection, 1900-1980s. Portland State University.

Warner, Mary. "Letter to Kal Szeckely,” June 17, 1975. Acc. A2001-022. PARC.

"What We Want." Rose City Copwatch. Accessed March 2, 2015. https://rosecitycopwatch.wordpress.com/about/.

"Who Is Policing the Police." NW Illustrator. KOIN 6, July 27, 1980. Acc. A0237-01. PARC.

"Why No Inquest?" The Oregonian, December 4, 1907.

Wolfe, Gregory B. "Western Union Letter from President Wolfe to Richard Nixon," May 6, 1970. In Sub-Series 7. President Office Records. Portland State University Special Collections.

Wolk, Anthony. "Letter from Anthony Wolk to President Wolfe," May 24, 1970. In SubSeries 7. President Office Records. Portland State University Special Collections..

"Youth Changes Plea in Cab Driver Holdup." The Oregonian, June 17, 1975.

Zimmerman, Katherine. "Letter to Donald McNamara," January 5, 1973. Acc. A2014-004. PARC. 